\title{
AVALIAÇÃO ERGONÔMICA DO PROJETO INTERNO DE CABINES DE FORWARDERS E SKIDDERS
}

\author{
GUSTAVO FONTANA
}

Dissertação apresentada à Escola Superior de Agricultura

"Luiz de Queiroz", Universidade de São Paulo, para obtenção do título de Mestre em Agronomia, Área de Concentração: Máquinas Agrícolas.

P I R A C I C A B A

Estado de São Paulo - Brasil

Setembro - 2005 


\section{AVALIAÇÃO ERGONÔMICA DO PROJETO INTERNO DE CABINES DE FORWARDERS E SKIDDERS}

\section{GUSTAVO FONTANA}

Engenheiro Agrícola

Orientador: Prof. Dr. FERNADO SEIXAS

Dissertação apresentada à Escola Superior de Agricultura "Luiz de Queiroz", Universidade de São Paulo, para obtenção do título de Mestre em Agronomia, Área de Concentração: Máquinas Agrícolas.

P I R A C I C A B A

Estado de São Paulo - Brasil

Setembro - 2005 
Dados Internacionais de Catalogação na Publicação (CIP) DIVISÃO DE BIBLIOTECA E DOCUMENTAÇÃO - ESALQ/USP

Fontana, Gustavo

Avaliação ergonômica do projeto interno de cabines de Forwarders e Skidders /

Gustavo Fontana. - - Piracicaba, 2005

80 p. : il.

Dissertação (Mestrado) - - Escola Superior de Agricultura Luiz de Queiroz, 2005.

Bibliografia.

1. Antropometria 2. Colheita 3. Ergonomia 4. Mecanização florestal 5. Tratores I. Título

CDD 631.3

"Permitida a cópia total ou parcial deste documento, desde que citada a fonte - O autor" 


\section{DEDICATÓRIA}

Dedico aos meus pais, José e Vera Fontana, pelo carinho e pelo apoio para superar os desafios durante a elaboração deste trabalho.

Aos meus irmãos Guilherme e Gabriel, pelo companheirismo e amizade de todas as horas.

Aos meus tios e tias, a minha avó pela contribuição em minha formação e pela ajuda nos momentos em que precisei. 


\section{AGRADECIMENTOS}

É extremamente prazeroso chegar ao fim de uma etapa, principalmente quando se sabe que não a atingimos sozinhos. Seria impossível escrever este trabalho sem registrar meus agradecimentos às pessoas que contribuíram para a sua realização:

A Escola Superior de Agricultura Luiz de Queiroz (ESALQ) pela excelente estrutura proporcionada durante o curso.

Ao Orientador Professor Doutor Fernando Seixas, pela orientação, conselhos e pela sua amizade.

Às empresas florestais Chamflora Mogi Guaçu Agroflorestal Ltda e Duraflora S.A por oferecer a oportunidade e os meios necessários para realização deste trabalho.

Aos funcionários e todos os operadores pelo auxílio indispensável em todas as etapas.

Agradeço à Fundação de Amparo à Pesquisa do Estado de São Paulo (FAPESP) pelo financiamento do projeto. 
À Fundacentro pelo empréstimo da cadeira antropométrica e pela colaboração para a realização deste trabalho.

Aos professores e funcionários do Setor de Máquinas Agrícolas do Departamento de Engenharia Rural da ESALQ/USP.

Aos amigos Pedro Abel Vieira Junior e família, Paulo Bettini, Gustavo Kazuo, Raphael (Briu), Gustavo Faulin, Adriano Barbosa (Tereré), Murilo, Romanelli, José Victor, Leonardo Mascarin, Marcos Mattos, Rouverson Pereira da silva e demais que me proporcionaram grandes momentos de amizade, alegria, incentivo e colaboração.

Aos amigos e colegas do curso de mestrado: André Pincelli, Rui, Wlademir (Kvera), Flávia (Rodízio), Rubén Collantes, Cassiano, Giuliano (CPI) pelo companheirismo de todas as horas.

À Deus por tudo... 


\section{SUMÁRIO}

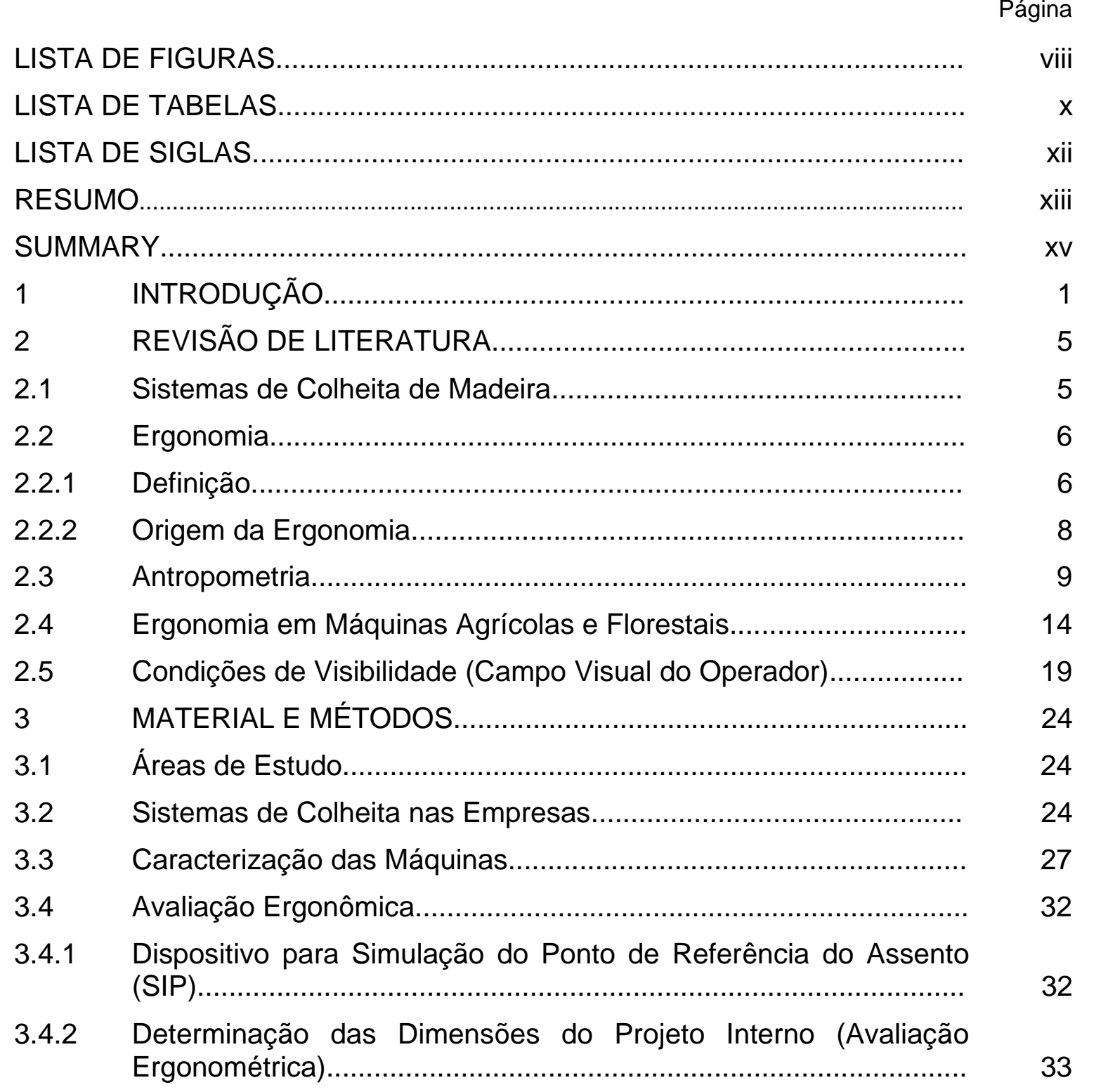


3.4.3 Dispositivo para Determinação de Medidas Antropométricas......... 36

3.4.4 Análise do Posicionamento Visual dos Instrumentos...................... 39

3.4.5 Dispositivo para Determinação da Visibilidade.............................. 39

3.4.6 Campo Visual do Operador...................................................... 40

3.4.7 Avaliação do Questionário........................................................... 42

4 RESULTADOS E DISCUSSÃO........................................... 44

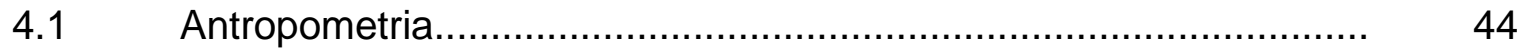

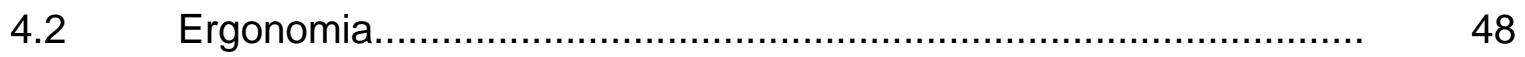

4.2.1 "Forwarder" Timberjack modelo 1210B................................... 48

4.2.2 "Forwarder" Timberjack modelo 1710D ......................... 51

4.2.3 "Forwarder" Valmet modelo 890.2 ............................ 53

4.2.4 "Forwarder" Volvo modelo A25C ............................. 56

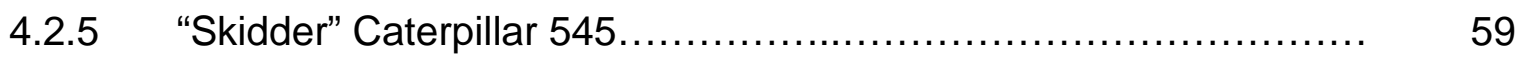

4.2.6 "Skidder" Tigercat 630B..................................... 62

4.2.7 Análise Comparativa entre os Modelos de Máquinas de Extração de Madeira...................................................................... 65

4.3 Avaliação do Campo Visual do Operador...................................... 67

4.4 Avaliação Geral dos Operadores................................. 72

4.4.1 "Forwarders" ................................................ 72

4.4.2 "Skidders".......................................................................

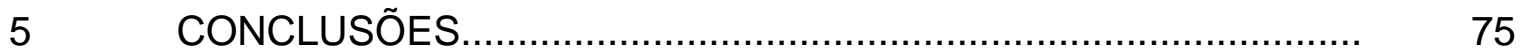

REFERÊNCIAS BIBLIOGRÁFICAS ................................................. 76 


\section{LISTA DE FIGURAS}

Página

1 Campos visuais do operador: A - campo visual estacionário; B campo visual dos olhos e $\mathrm{C}$ - campo visual obtido com o movimento da cabeça.

Áreas de visão ótima e máxima.

3 Máquinas florestais utilizadas no sistema de colheita mecanizado na empresa A....

4 Máquinas florestais utilizadas no sistema de colheita mecanizado na empresa B....

5 "Forwarder" Timberjack modelo 1210B........................... 28

$6 \quad$ "Forwarder" Timberjack modelo 1710D ............................ 28

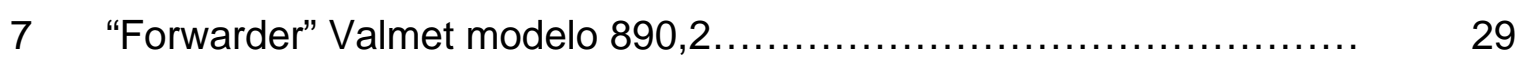

8 "Forwarder" Volvo modelo A25C ..................................... 29

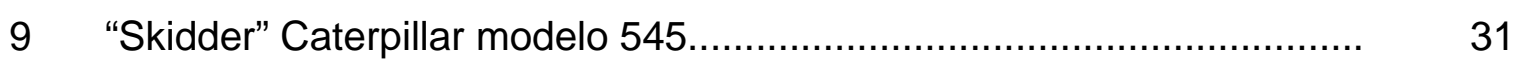

10 "Skidder" Tigercat modelo 630B................................................ 31

11 Dispositivo para simulação do SIP................................................... 32

12 Equipamento de medidas do SIP aos órgãos de comando................... 33

13 Áreas de máximo e ótimo acesso aos órgãos de comando, nas três dimensões.

14 Ficha de coleta dos dados antropométricos........................................ 36

15 Medidas tomadas com régua graduada...................................... 37

16 Cadeira com escalas de medições antropométricas............................ 38

17 Dispositivo "GF" para determinação da visibilidade............................ 38

18 Área do teste de visibilidade dos "skidders".................................... 42

19 Área do teste de visibilidade dos "forwarders"................................... 42

20 Modelo da ficha para avaliação do acesso aos órgãos de comando dos operadores de "Forwarders" e "Skidders" (SkogForsk,1999).......... 
21 Localização dos órgãos de comandos do "forwarder" Timberjack 1210B, nas três dimensões.

22 Área de visão ótima e máxima de comandos do "forwarder" Timberjack 1210B

23 Localização dos órgãos de comandos do "forwarder" Timberjack 1710D, nas três dimensões.

24 Área de visão ótima e máxima de comandos do "forwarder" Timberjack 1710D

25 Localização dos órgãos de comandos do "forwarder" Valmet 890,2 nas três dimensões.

26 Área de visão ótima e máxima de comandos do "forwarder" Valmet 890,2

27 Localização dos órgãos de comandos do "forwarder" Volvo A25C nas três dimensões.

28 Área de visão ótima e máxima de comandos do "forwarder" Volvo A25C

29 Localização dos órgãos de comandos do "skidder" Caterpillar 545, nas três dimensões.

30 Área de visão ótima e máxima de comandos do "skidder" Caterpillar 545.

31 Localização dos órgãos de comandos do "skidder" Tigercat 630B, nas três dimensões.

32 Área de visão ótima e máxima de comandos do "skidder" Tigercat 630B.

33 Área de visibilidade nula (hachurada) dos "forwarders" com os respectivos campos visuais dos operadores em posição de deslocamento com as máquinas.

34 Área de visibilidade nula (hachurada) dos "skidders" com os respectivos campos visuais dos operadores em posição de deslocamento com as máquinas. 


\section{LISTA DE TABELAS}

Página

1 Valores médios dos dados antropométricos de diferentes paises (cm)

Características das marcas e modelos de "forwarders"

Características das marcas e modelos de "skidders".

Conceitos da avaliação espacial dos comandos nas coordenadas $\mathrm{x}-\mathrm{y}$ e $\mathrm{x}-\mathrm{z}$.

Conceitos da avaliação espacial dos instrumentos de verificação nas coordenadas $x-y$ e $x-z$...

Padrão antropométrico dos operadores de máquinas florestais das empresas em estudo

Comparação do padrão antropométrico entre os operadores de máquinas florestais dos EUA $\left(^{*}\right)$ e das empresas em estudo.

8 Distribuição espacial dos trinta e cinco comandos do "forwarder" Timberjack 1210B na avaliação espacial das coordenadas $x-y$ e $\mathrm{X}-\mathrm{Z}$.

Distribuição espacial dos cinqüenta e um comandos do "forwarder" Timberjack 1710D na avaliação espacial das coordenadas $x-y$ e $x-z$.

Distribuição espacial dos quarenta e oito comandos do "forwarder" Valmet 890.2 na avaliação espacial das coordenadas $x-y$ e $x-z$.

11 Distribuição espacial das cinco luzes de advertência do "forwarder" Valmet 890.2 do ponto de vista do campo visual...

12 Distribuição espacial dos trinta e um comandos do "forwarder"

12 Distribuição espacial dos trinta e um comandos do "forwarder"

13 Distribuição espacial das trinta luzes de advertência do "forwarder" Volvo A235C do ponto de vista do campo visual.

14 Distribuição espacial dos vinte e quatro comandos do "skidder" Caterpillar 545 na avaliação espacial das coordenadas x-y e x-z..

15 Distribuição espacial das dezenove luzes de advertência do "skidder" Caterpillar 545 do ponto de vista do campo visual...........

16 Distribuição espacial dos dezenove comandos do "skidder" Tigercat 630B na avaliação espacial das coordenadas x-y e x-z... 
17 Distribuição espacial das dezenove luzes de advertência do "skidder" Tigercat 630B do ponto de vista do campo visual.....

18 Avaliação da localização dos comandos (\%) com 0 assento localizado na posição média.

19 Avaliação da localização das luzes de advertência e instrumentos de verificação (\%) com o assento localizado na posição média.....

20 Áreas de visibilidade nula do solo (Avn), composta pela área do trator e a sombra projetada para os campos visuais $A, B$ e $C$ (Acv), para os operadores em posição de deslocamento com a máquina.

21 Relação (\%) entre a área de visibilidade nula (Avn) e a área total dos campos visuais A, B e C (Acv), dos operadores em posição de deslocamento com a máquina.

Médias atribuídas pelos operadores de "forwarders".

23 Médias atribuídas pelos operadores de "skidders". 


\section{LISTA DE SIGLAS}

ABERGO Associação Brasileira de Ergonomia

ABNT Associação Brasileira de Normas Técnicas

AVC Área dos Campos Visuais

AVN Área de Visibilidade Nula

CV Cavalo - Vapor

dBA Decibéis

GF Gustavo Fontana

IEA International Ergonomics Association

ILO International Labour Office

ISO International Organization for Standardization

Kg Quilograma

KW Quilowatts

Lm Lumen

SAE Society of Automotive Engineers

SIP Seat Index Point 


\title{
AVALIAÇÃO ERGONÔMICA DO PROJETO INTERNO DE CABINES DE FORWARDERS E SKIDDERS
}

\author{
Autor: GUSTAVO FONTANA \\ Orientador: Prof. Dr. FERNANDO SEIXAS
}

\section{RESUMO}

O presente trabalho teve por objetivo realizar a avaliação ergonômica da cabine de seis modelos de máquinas florestais utilizadas na extração de madeira (quatro "forwarders" e dois "skidders"), quanto ao posicionamento de comandos e instrumentos e o campo visual do operador, com base nas características antropométricas do operador brasileiro. As análises foram feitas em máquinas operando em áreas de colheita de madeira pertencentes a duas empresas florestais, localizadas nos municípios de Mogi Guaçu e Lençóis Paulista, Estado de São Paulo. Para a avaliação do posicionamento dos órgãos de comando foram determinadas as distâncias dos mesmos a partir do Ponto de Referência do Assento nas três dimensões ( $x, y$ e z), além de uma avaliação qualitativa com os operadores dos tratores florestais em estudo, que, através de notas, manifestaram sua satisfação com relação à localização dos comandos e outras variáveis ergonômicas. A avaliação antropométrica dos operadores foi 
feita por duas medidas, uma em pé e outra por meio de uma cadeira especial desenvolvida pela Fundacentro, obtendo-se, a partir dela, as áreas de máximo e ótimo acesso quanto à localização dos órgãos de comando. O campo visual do operador foi determinado com o auxílio de um dispositivo de iluminação com a demarcação da área sombreada, considerada como campo de visibilidade nula. Concluiu-se que a melhor máquina, quanto ao posicionamento de comandos, foi o "forwarder" Valmet 890.2, seguido pelo "skidder" Caterpillar 545 , sendo os únicos tratores que apresentaram mais da metade dos comandos bem posicionados, $66,7 \%$ e $54,5 \%$ respectivamente. O "forwarder" Valmet 890.2 também apresentou o melhor campo visual, sendo que, neste quesito, todos os modelos de "forwarders" foram superiores aos "skidders". Os resultados deste estudo demonstraram um projeto ergonômico da disposição de comandos nas cabines dos tratores florestais não muito favorável ao conjunto de operadores brasileiros analisados.

PALAVRAS-CHAVE: antropometria, ergonomia, tratores florestais, colheita. 


\title{
ERGONOMIC EVALUATION OF THE INTERNAL PROJECT OF CABINS OF FORWARDERS AND SKIDDERS
}

\author{
Author: GUSTAVO FONTANA \\ Adviser: Prof. Dr. FERNANDO SEIXAS
}

\section{SUMMARY}

The objective of this work was the cab evaluation of four forwarders and two skidders models, considering the positioning of commands and instruments and the operator visual area, on the basis of the anthropometrics characteristics of a sample of Brazilians operators. The analyses had been made in machines operating in relevant areas of wooden forest from two forest companies, located in Mogi Guaçu and Lençóis Paulista municipalities, State of São Paulo. The command position was determined in three dimensions ( $x, y$ and $z$ ), considering the operator's seat reference point as the origin. A qualitative evaluation with the operators of the forest tractors was also done, revealing their satisfaction about several ergonomics factors related with the forest machines. The anthropometric evaluation of the operators was made by means of a special chair developed by the Fundacentro, resulting in the areas of maximum and excellent access for the 
commands localization. The visual area of the operator was determined with a illumination device and the landmark of the shaded area, considered as a field of null visibility. The machine with the best commands position, in accordance with the biotype of this set of Brazilians operators, was the forwarder Valmet 890,2, followed by the skidder Caterpillar 545, being the only tractors that had presented more than half of the commands, $66.7 \%$ and $54.5 \%$ respectively, well positioned. The forwarder Valmet 890,2 also presented the best visual field, with all forwarders models being superiors, in this evaluation, to the skidders. The results of this study had demonstrated, in terms of commands position, ergonomic projects of those forest machines not very favorable to the set of analyzed Brazilians operators.

KEY WORDS: anthropometric, ergonomic, forest tractors, harvesting. 


\section{INTRODUÇÃO}

O processo de mecanização em larga escala da colheita florestal é recente no Brasil, intensificando-se na década de $1990 \mathrm{com}$ a abertura das importações e a possibilidade de aquisição de máquinas de alta tecnologia.

$\mathrm{Na}$ maioria das vezes, a mecanização florestal envolve o uso de máquinas adaptadas ou importadas de países com diferentes condições climáticas e características antropométricas dos operadores. O custo elevado dessas máquinas exige o máximo de aproveitamento de todas as suas funções durante execução contínua das tarefas a elas atribuídas, bem como demanda estudos no sentido de adequá-las às condições de trabalho no Brasil.

Nesse contexto, é importante introduzir-se o aspecto ergonômico nos estudos para proporcionar melhores condições de trabalho aos operadores das máquinas utilizadas nessa atividade. A ergonomia tem contribuído significativamente para a melhoria das condições de trabalho humano. Entretanto, na maioria dos países em desenvolvimento, é um conceito relativamente novo e essa contribuição ainda é pequena, em função do baixo número de estudos e da restrita divulgação dos seus benefícios (Minette, 1996).

A atividade principal dos operadores dessas máquinas é realizada no posto de condução na cabine, daí a importância da aplicação de critérios ergonômicos que permitam estabelecer a correta adaptação dos componentes do sistema homem-máquina. Para isso, é preciso levar em conta as características dos operadores e do trabalho que se realiza, alcançando deste modo uma maior eficiência produtiva, assim como um maior grau de conforto e 
segurança na tarefa, proporcionando-se uma melhoria das condições de trabalho.

As máquinas de colheita florestal foram desenvolvidas basicamente para dois sistemas: a) no de "toras curtas", preponderante nos países escandinavos, uma máquina, como o "harvester", executa a derrubada, o desgalhamento e o traçamento no local do corte, com a extração sendo feita pelo "forwarder" até a margem da estrada; b) no de "toras longas", predominante nos países da América do Norte, o "feller-buncher" realiza a derrubada e o agrupamento das árvores em feixes, preparando-as para que os tratores arrastadores ("skidders") efetuem a operação de arraste da madeira até o local de processamento.

Conforme a tecnologia tem avançado, maior é a preocupação com a relação homem-máquina, objetivando uma carga de trabalho mais favorável ao operador e a conseqüente minimização do desgaste físico e psíquico decorrente das condições de trabalho. Fatores ergonômicos estão relacionados com aspectos importantes a serem observados em uma avaliação de máquinas, visando maior conforto e segurança do operador e maior produtividade durante a realização do trabalho.

A norma que trata de ergonomia no Brasil é a NR-17 do Ministério do Trabalho, publicada em 1978 e modernizada em 1990. Essa norma tem por objetivo estabelecer parâmetros que permitam a adaptação das condições de trabalho às características psicofisiológicas dos trabalhadores, de modo a proporcionar o máximo conforto, segurança e desempenho. Entretanto, não há indicação para avaliação ergonômica de máquinas florestais, conforme já existente nos países escandinavos.

O manual "Ergonomic Guidelines for Forest Machines", um guia desenvolvido por SkogForsk (1999), normatiza a avaliação ergonômica de máquinas florestais, na esperança de incentivar o desenvolvimento de máquinas seguras e de fácil operação, dando prioridade à saúde do operador. Esse manual apresenta alguns critérios de avaliação para o projeto do posto de operação, os controles, o equipamento e os procedimentos de manutenção. 
A avaliação ergonômica deve ser um fator decisório na compra de uma máquina florestal, pois, além dos critérios técnicos e econômicos, a condição ergonômica da máquina tem influência direta sobre o rendimento do trabalho. A análise ergonômica de máquinas deve considerar os fatores descritos anteriormente, baseando-se nas características antropométricas do operador a que se destina. A antropometria é o estudo das medidas físicas do corpo humano (lida, 2001). Do ponto de vista antropométrico, o projeto incorreto dos postos de trabalho, bem como dos equipamentos e das ferramentas neles existentes, impõe ao trabalhador de colheita florestal solicitações excessivas e desnecessárias, que podem resultar em lombalgia, desconforto, fadiga, redução na produtividade, erros e acidentes. Em virtude disso, a ergonomia utiliza dados da antropometria para adaptar as medidas de espaços de trabalho, às medidas físicas do corpo humano. lida (2001) define espaço de trabalho como sendo o espaço imaginário necessário para realizar os movimentos requeridos pelo trabalho.

Estudos antropométricos realizados durante várias décadas comprovaram que existem diferenças nas medidas antropométricas, sendo estas diferenciadas por idade, sexo e raça (Panero \& Zelnik, 1993). Com a crescente internacionalização da economia, o mercado exige uma certa padronização dos produtos, ao mesmo tempo em que permita a adaptação das máquinas ao maior número possível de tipos de usuários.

No caso de máquinas de extração de madeira, o "forwarder" é considerado a máquina melhor projetada do ponto de vista ergonômico e a sua operação como menos cansativa, favorecendo a sua adoção em países com legislação trabalhista mais rigorosa (Makkonen, 1989).

Neste contexto, o presente trabalho teve por objetivo realizar a avaliação ergonômica da cabine de dois tipos de máquinas florestais utilizadas na extração de madeira ("forwarders" e "skidders"), quanto ao posicionamento de comandos, instrumentos e campo visual, considerando-se as características 
antropométricas do operador brasileiro, e concluir pela sua adaptação ou não ao biótipo do nosso trabalhador. 


\section{REVISÃO DE LITERATURA}

\subsection{Sistemas de Colheita de Madeira}

A colheita florestal é o conjunto de operações realizadas no maciço florestal, visando preparar e transportar a madeira até o seu local de utilização, dispondo-se de técnicas e padrões estabelecidos com o objetivo de transformála em produto final (Marques, 1994).

Sistema de colheita de madeira pode ser definido como "o conjunto de atividades, integradas entre si, de forma a permitir um fluxo constante de madeira. Não devem ser permitidos pontos de estrangulamento no processo, e os equipamentos utilizados devem ser levados à sua máxima utilização" (Seixas, 1983).

Existem vários sistemas de colheita de madeira, variando de empresa para empresa e dependendo da topografia, do rendimento volumétrico dos povoamentos, do tipo de povoamento, uso final da madeira, das máquinas, dos equipamentos e dos recursos disponíveis. Basicamente, a colheita é constituída de cinco etapas: corte, extração, carregamento, transporte e o descarregamento da madeira (Souza, 1985). Deste modo, cada uma é seqüencialmente dependente da outra no tempo e espaço, de modo que qualquer interferência em um estágio da produção pode destruir a seqüência e afetar a produção.

Os principais sistemas de colheita florestal, de acordo com Machado (2002), são divididos em sistemas de toras curtas, de toras longas e de cavacos de madeira. 
O sistema de "toras curtas" é mais utilizado nos países escandinavos, sendo o mais antigo sistema empregado no Brasil. Um conjunto mecanizado típico é composto por "harvester" e "forwarder". O "harvester" executa simultaneamente as operações relacionadas com o corte florestal (derrubada, desgalhamento, destopamento, toragem e enleiramento) e é composto por uma máquina base de pneus ou esteira, uma lança hidráulica e um cabeçote. $\mathrm{O}$ "forwarder" (auto carrregável) é uma máquina desenvolvida para executar a extração de madeira da área de corte para a margem da estrada ou pátio intermediário.

No sistema de "toras longas", predominante nos países da América do Norte, utiliza-se um conjunto mecanizado composto por um "feller-buncher", constituído de um trator de esteiras ou pneus com cabeçote, que realiza o corte e o agrupamento das árvores em feixes, preparando-as para que os tratores "skidders" efetuem o arraste dos feixes de toras até um pátio temporário ou nas margens das estradas.

O sistema de "cavacos" é semelhante ao sistema de toras longas, onde o "feller-buncher" realiza a derrubada das árvores, preparando-as para que os tratores arrastadores ("skidders") ou ("clam-bunk skidder") efetuem a operação de arraste da madeira até o picador, transformando-as em cavacos, com todo o processo realizado dentro do próprio talhão, posteriormente transportados para a industria.

\subsection{Ergonomia}

\subsubsection{Definição}

A ergonomia é definida como a adaptação do trabalho ao homem (Vieira, 2000; lida, 2001). O trabalho abrange as máquinas, equipamentos e também toda a situação em que ocorre o relacionamento entre o homem e seu trabalho. É muito mais difícil adaptar o homem ao seu ambiente de trabalho, significando que a ergonomia parte do conhecimento do homem para fazer o projeto do trabalho, ajustando-o às capacidades e limitações humanas. 
De acordo com Dul \& Weerdmeester (2001), o termo ergonomia é derivado das palavras gregas "Ergon" (trabalho), e "Nomos" (regras). Laville (1977) a define como "o conjunto de conhecimentos científicos relativos ao homem e necessários à concepção de instrumentos, máquinas e dispositivos que possam ser utilizados com o máximo de conforto, segurança e eficiência".

O que se observa, normalmente, é a adaptação do homem ao trabalho. O inverso é mais difícil, pois o trabalho nem sempre é adaptável ao ser humano. Daí temos que o homem é o ponto de partida para projetos de trabalho, adaptando-os às capacidades e limitações humanas (Santos, 1999).

Segundo Tewark \& Datta (1983), "Ergonomia pode ser definida como sendo o conjunto de estudos que visam a organização metódica do trabalho em função das relações homem-máquina e seus efeitos, considerando-se a facilidade de ocupar o equipamento, o conforto, a visibilidade, a localização, o tamanho e a forma de seus componentes".

De acordo com lida (2001), "Ergonomia é o estudo do relacionamento entre o homem e seu trabalho, equipamento e ambiente e, particularmente, a aplicação dos conhecimentos de anatomia, fisiologia e psicologia na solução dos problemas surgidos desse relacionamento". Já para Couto (1995), "Ergonomia é um conjunto de ciências e tecnologias que procura a adaptação confortável e produtiva entre o ser humano e seu trabalho, basicamente procurando adaptar as condições de trabalho às características do ser humano".

Wisner (1987) define a ergonomia num ponto de vista mais restrito. Para ele, a ergonomia é o conjunto dos conhecimentos científicos relativos ao homem e necessários para a concepção de ferramentas, máquinas e dispositivos, que possam ser utilizados com o máximo conforto, segurança e eficácia.

Para a realização dos seus objetivos a ergonomia estuda uma diversidade de fatores que são: o homem e suas características físicas, fisiológicas e psicológicas; a máquina que se constitui de todas as ferramentas, 
mobiliário, equipamento e instalações; o ambiente que contempla a temperatura, ruídos, vibrações, luz, cores, etc.; a informação que refere-se ao sistema de transmissão das informações; a organização que constitui todos os elementos citados no sistema produtivo considerando horários, turnos e equipes; e as conseqüências do trabalho onde entram as questões relacionadas com os erros e acidentes além da fadiga e o estresse (lida, 2001).

Para Patosaari (1983), sob o ponto de vista ergonômico, grande parte das atividades do setor florestal envolve consideráveis e inaceitáveis riscos e perigo à saúde. No entanto, devido ao fator humano envolvido, não é fácil a implementação de medidas apropriadas e realísticas para sua melhoria.

A ergonomia se preocupa com todos esses fatores objetivando a segurança, satisfação e bem estar dos trabalhadores em seus relacionamentos com os sistemas produtivos (Pinheiro \& Marziale, 2000).

\subsubsection{Origem da Ergonomia}

Conforme Santos \& Fialho (1997), o termo ergonomia foi definido primordialmente como o estudo das leis do trabalho. Esta ciência surgiu na Inglaterra logo após a Segunda Guerra Mundial.

Desde os primórdios da humanidade, já se aplicavam conceitos ergonômicos virtuais sobre o trabalho humano, como a escolha da melhor maneira para desempenhar uma função, o manuseio de objetos, a adequação às variações de temperatura, as formas e postura de trabalho, dentre outros. Com a Revolução Industrial ocorrida no século XIX, os princípios sobre o trabalho humano foram severamente questionados, onde, segundo Couto (1995), privilegiava-se os inventos em detrimento dos trabalhadores. Isso contribuiu para os manifestos socialistas e para o surgimento das teorias de Marx e Engels. O grande salto científico que culminou com o patamar de desenvolvimento da ergonomia atual, procedeu-se logo após a Segunda Grande Guerra, como resultado do trabalho interdisciplinar entre 11 profissionais que se dedicaram para melhorar a eficiência dos armamentos e 
com isso diminuir os erros humanos nos campos de batalha (Santos \& Fialho, 1997). Sob este ponto de vista, pode se dizer que a ergonomia é mais um fruto das necessidades oriundas da máquina da guerra, que, por sua vez, proporciona a geração de tecnologia inovadora nas mais diversas áreas do conhecimento humano.

Couto (1995) afirmou que a ergonomia aplicada ao trabalho teve maior respaldo com o início da corrida espacial, a partir de 1950, principalmente pela influência americana. O mesmo autor cita que, entre os anos de 1920 e 1950, o princípio máximo regido sobre o trabalho nos EUA era a necessidade de adaptação do homem ao trabalho, ou seja, a prioridade era construir a máquina e o posto de trabalho e posteriormente encontrar o ser humano ideal para tal situação. Após este período, o mesmo princípio foi alterado, passando a considerar a adaptação do trabalho ao homem, o qual perdura até nossos tempos.

No Brasil a Associação Brasileira de Ergonomia (ABERGO) foi fundada em 1983 e também é filiada à Internation Ergonomics Association (IEA) (Dul \& Weerdmeester, 2001).

Alguns conhecimentos em ergonomia foram convertidos em normas oficiais, com o objetivo de estimular a aplicação dos mesmos. No Brasil a norma regulamentadora NR 17 - Ergonomia, Portaria $n^{\circ} 3214$, de 08.06 .78 do Ministério do Trabalho, modificada pela Portaria $n^{\circ} 3.751$ de 23.11.1990 do Ministério do Trabalho, dispõe sobre o assunto (Dul \& Weerdmeester, 2001; Vieira, 2000; Cherem, 2001; Rossi \& Silva, 2001).

\subsection{Antropometria}

A antropometria é a ciência que estuda as medidas físicas do corpo humano e a aplicação de forças. Uma das aplicações das medidas antropométricas na ergonomia é o dimensionamento do espaço de trabalho no sentido de se manter uma boa postura (Woodson \& Conover, 1964). 
As medidas antropométricas permitem verificar o grau de adequação de produtos em geral, quando se utiliza qualquer ferramenta ou instrumento (Minette, 1996). Segundo Moraes (1983) quando equipamentos ou máquinas se adaptam adequadamente ao organismo, sob o ponto de vista dimensional, os erros, os acidentes, o desconforto e a fadiga diminuem sensivelmente.

Assim, o projeto incorreto do ponto de vista antropométrico de postos de trabalho, equipamentos, ferramentas e meios auxiliares neles existentes, impõem ao trabalhador de colheita florestal solicitações excessivas e desnecessárias, podendo resultar em desconforto, fadiga, redução na produtividade, erros e acidentes.

Segundo Minette (1996) o levantamento de dados antropométricos mostra a variabilidade das dimensões de uma população, logo, não podem ser generalizados à medida que se referem a uma população de outra região, com diferentes níveis socioeconômico, idade e sexo.

As medidas antropométricas permitem verificar o grau de adequação de produtos em geral, onde a qualidade ergonômica passa pela sua adequação antropométrica (Silva, 2003). A importância das medidas ganhou especial interesse na década de 40, devido à necessidade da produção em massa, em função do esforço de guerra.

lida (2001) explica que a ciência da antropometria, assim como a ergonomia, teve seu crescimento influenciado pela Segunda Grande Guerra, pelo surgimento de sistemas complexos de trabalho e pela necessidade crescente de aumento da produção. No início, a antropometria se preocupava somente com as grandezas médias da população, como peso, estatura e idade, sendo que no início de 1900 os seus propósitos se relacionavam com produtos comerciais, registros médicos ou seleção militar. Posteriormente, passaram-se a considerar as variações entre grupos, os alcances de movimentos e a influência de variáveis como as etnias, as regiões geográficas e as culturas (Panero \& Zelnik,1993; lida, 2001). Segundo os mesmos autores, as características antropométricas do ser humano podem ser modificadas 
conforme alterações da idade, do sexo, da alimentação, do grupo laboral, dentre outras. Portanto, a ergonomia utiliza dados da antropometria para adaptar as medidas físicas do corpo humano com o espaço de trabalho, assentos, roupas, máquinas, ferramentas, instrumentos, posição dos controles e comandos etc.

As medidas antropométricas estão relacionadas com a média e o desvio padrão, explica lida (2001). A média corresponde simplesmente à média aritmética das medidas de uma determinada amostra populacional, já o desvio padrão, representa o grau de variabilidade dessa medida dentro da amostra escolhida. Deve-se ter o cuidado de não se projetar para a média da população, supondo estar projetando para a maioria (Silva, 2003). Para lida (2001), uma pessoa média ou padrão é uma abstração matemática obtida por medidas quantitativas, logo poucas pessoas podem ser enquadradas nessa classificação. O projeto para a média se baseia na idéia de maximização do conforto para a maioria da população alvo, o que não se procede na prática, porque existem diferenças nas médias entre homens e mulheres, e também em relação à média geral de toda a população, o que beneficia apenas uma pequena parcela desta.

Por regra geral, Panero \& Zelnik (1993), explicam que os dados antropométricos são expressos em percentis, que por sua vez, significam a proporção da população cuja medida é inferior a um determinado valor. Um percentil de 90,0\% indica que uma variável possui magnitude igual ou inferior a este valor, e que os 10,0\% restantes correspondem aos extremos superior e inferior da referida variável. Assim, para viabilizar o projeto ergonômico, uma pequena percentagem populacional não deve ser considerada, a qual representa características dimensionais extremas.

Segundo lida (2001) e Silva (2003), alguns equipamentos podem ter certas medidas ajustáveis para acomodar melhor os seus usuários (assentos de tratores agrícolas, por exemplo), o qual são dimensionados para cobrir a faixa entre 5,0 a 95,0\% da população envolvida, considerando medidas mínimas e 
máximas. Na maior parte dos casos, não compensa técnica e economicamente resolver os problemas para abranger $100,0 \%$ da população, sendo preferível desenvolver produtos específicos para essa minoria.

Estudos de Yadav \& Tewari (1998), relatam a importância de considerar as características antropométricas e biomecânicas dos operadores no projeto do posto de operação de tratores agrícolas. O assento do trator e a posição dos comandos de operação de mãos e pés devem ser projetados para acomodar 90,0\% da população com possibilidades de conduzir tratores agrícolas. Schlosser et al. (2002 a) afirmam que um mesmo operador de trator agrícola pode apresentar medidas que se enquadrem dentro e fora dos percentis, o que dificulta o projeto de um posto de operação coerente.

Grandjean (1998) afirma que a pesquisa antropométrica já evoluiu bastante nos países desenvolvidos, o que não se verifica no Brasil. Assim, os dados antropométricos utilizados para embasar os projetos de tratores agrícolas comercializados no Brasil, normalmente são de cidadãos estrangeiros, devido à carência de informações antropométricas dos operadores brasileiros. Além do mais, grande parte do mercado brasileiro de tratores agrícolas é dominado por empresas estrangeiras, o que desestimula a realização de pesquisa antropométrica para este mercado, já que é mais barato considerar tais informações de outras regiões mais evoluídas. Isso é uma incoerência, pois não se sabe qual o padrão antropométrico seguido e também não se pode afirmar que este padrão esteja totalmente incorreto. As soluções para este impasse são os ensaios e a pesquisa antropométrica.

Schlosser et al. (2002 a) desenvolveram uma pesquisa que traçou o perfil antropométrico dos operadores de tratores agrícolas da região central do Rio Grande do Sul, onde foi comprovado que o padrão antropométrico dos operadores de tratores agrícolas dessa região é diferente daquele dos países desenvolvidos. Os dados obtidos demonstram que existem diferenças entre o biótipo do operador utilizado pela indústria de tratores agrícolas e o do operador da região, com exceção do apoio do assento (comprimento da almofada do 
assento), para este último. Os autores verificaram que para cada medida, os limites inferior e superior do intervalo onde se encontram 90,0\% dos operadores avaliados foram, respectivamente, menores e maiores que o padrão utilizado pela indústria brasileira, o que caracterizou uma maior variação. Concluiu-se que os tratores agrícolas que se encontram atualmente em comercialização no Brasil podem não oferecer o conforto necessário ao operador da região estudada, havendo necessidade de algumas modificações no projeto dos tratores, em relação àqueles adequados aos operadores de países desenvolvidos.

Da mesma forma, Kochler (1999) estudou os operadores de colhedoras da região nordeste do Rio Grande do Sul, relatando sobre o seu perfil antropométrico e sobre diversos aspectos pertinentes à rotina de trabalho, ergonomia das máquinas e sobre as conseqüências do trabalho. $\mathrm{O}$ autor concluiu que a medida da altura do assento até o apoio de braços do operador se encontrava num patamar inferior ao recomendado pelos dados antropométricos para o homem padrão médio daquela região e que ocorria o inverso com a altura do assento em relação à plataforma de apoio para os pés.

Estudos realizados durante várias décadas comprovaram que existem diferenças nas medidas antropométricas, inclusive dentro de um mesmo país, sendo estas diferenciadas por idade, sexo e raça (Panero \& Zelnik, 1993). Jürgens et al. (1990) detalham as diferentes medidas de estatura em alguns países, ressaltando a diferença entre as populações da América Latina e os países da América do Norte e Escandinávia (Tabela 1). Com a crescente internacionalização da economia, o mercado passou a exigir uma certa padronização dos produtos, ao mesmo tempo em que se permita a adaptação das máquinas ao maior número de usuários.

Thomas et al. (2001) avaliaram as dimensões antropométricas dos operadores de "skidder" de uma região localizada no Sul dos Estados Unidos. Os dados antropométricos coletados foram comparados com o banco de dados existente da "Society of Automotive Engineers" (SAE) e com as recomendações 
da "International Labour Office" (ILO). Os resultados indicaram que os operadores de "skidder" da região avaliada eram mais altos, enquanto que para a altura dos olhos, a partir do assento e na posição sentado, os resultados eram semelhantes a SAE e a ILO. Outro fator que se destacou foi que os operadores avaliados estavam acima do peso de acordo com a SAE.

Tabela 1. Valores médios dos dados antropométricos de diferentes paises (cm)

\begin{tabular}{cccc}
\hline & Estatura & $\begin{array}{c}\text { Altura do assento - } \\
\text { cabeça }\end{array}$ & $\begin{array}{c}\text { Altura do pé - } \\
\text { joelho }\end{array}$ \\
\hline $\begin{array}{l}\text { América do Norte } \\
\text { América Latina }\end{array}$ & 179,0 & 93,0 & 55,0 \\
Europa & 167,0 & 81,6 & 42,0 \\
\cline { 3 - 4 } & & & 55,0 \\
Norte & 181,0 & 95,0 & 55,0 \\
Lentral & 177,0 & 94,0 & 55,0 \\
Sudeste & 175,0 & 91,0 & 53,5 \\
\hline
\end{tabular}

\subsection{Ergonomia em Máquinas Agrícolas e Florestais}

A preocupação com o conforto e a segurança do operador tem chamado a atenção de profissionais de diversas áreas no sentido de considerar os fatores humanos na concepção dos projetos de tratores agrícolas, em razão das adversidades impostas pela natureza no meio agrícola e também da periculosidade que essas máquinas apresentam e dos acidentes envolvidos nesse contexto.

Silveira (1987) afirma que na escolha de uma máquina agrícola não se deve avaliar somente a potência, o consumo, o torque e outros aspectos ligados ao desempenho do equipamento, mas também a segurança de quem vai operá-la, pois a capacidade operacional do trabalho agrícola depende das condições em que ele é realizado. 
Operar um trator agrícola pode ser uma tarefa árdua, se forem consideradas todas as limitações e adversidades presentes no ambiente de trabalho agrícola. O operador desta máquina trabalha num ambiente que pode ser afetado por uma série de fatores oriundos da própria máquina e do meio ambiente, como os ruídos, as vibrações, as poeiras, a temperatura, a umidade, a iluminação, dentre outros (Márquez, 1997; Schlosser et al., 2002 b). Debiasi (2003) relata que a presença de itens relacionados ao conforto e ergonomia é menor quanto mais antigos forem os tratores agrícolas, implicando numa maior severidade dos efeitos dos fatores ambientais sobre operador, nessas condições.

Segundo Liljedahl et al. (1996), os fatores humanos, quando corretamente incorporados ao projeto, permitem que o operador faça uma grande quantidade de tarefas complexas com eficiência, segurança e um mínimo de fadiga. Em geral, os fatores humanos incluem itens como conforto, visibilidade, adequação da temperatura, minimização dos ruídos e vibrações e localização e distribuição adequada dos comandos de operação. Proporcionar conforto e segurança ao operador, sem afetar substancialmente o custo das máquinas, é um ganho de considerável importância que almejam todos os engenheiros de projeto de sistemas homem-máquina.

A perfeita incorporação dos fatores humanos ao projeto do trator colabora para uma melhor interação homem-máquina. Estudos de Witney (1988) indicam que o operador interage com a máquina de duas formas principais: primeiramente, ele recebe as informações do painel e o desempenho da máquina e, depois, reage a essas informações. O mesmo autor cita que o projeto adequado do trator agrícola colabora para a diminuição da carga física e mental do operador, significando uma redução das possibilidades de ocorrência de acidentes e um melhor rendimento de trabalho. Assim, o dimensionamento adequado do assento e dos comandos de operação, bem como a correta localização destes, aumenta a segurança e eficiência na operação do trator, diminuindo o tempo de reação às diferentes situações que se sucedem durante 
a jornada de trabalho. Da mesma forma, Liljedahl et al. (1996) afirmam que a correta disposição dos comandos de operação exerce papel fundamental na interação homem/máquina, aumentando o desempenho do operador e diminuindo seus erros.

Por outro lado, o posicionamento e as características das vias de acesso ao posto de operação do trator agrícola podem ser causas de inúmeros acidentes, principalmente quando não se dispõe de estribos e corrimões para o uso do tratorista (Robin, 1987; Márquez, 1997). Segundo os mesmos autores, os aspectos que assumem maior importância sob o ponto de vista ergonométrico são os acessos e as dimensões do posto de operação, bem como o posicionamento dos órgãos de comando.

Uma característica que envolve a operação de tratores agrícolas é a necessidade de controlar simultaneamente a direção do trator e supervisionar o trabalho executado pelos implementos acoplados na parte traseira do trator, constituindo-se num enorme desafio para a ergonomia.

Segundo lida (2001), o operador de trator gasta de 40,0 a 60,0\% do seu tempo olhando para trás, o que gera um grande número de movimentos rotacionais da cabeça do operador, chegando até 15 a 20 rotações por minuto. Esse fato faz com que o operador mantenha o pescoço torcido para trás, com o intuito de diminuir a quantidade dessas rotações, porém fica aumentada a tensão dos músculos do pescoço, provocando fadiga prematura dos músculos do pescoço e da coluna vertebral.

Segundo Yadav \& Tewari (1998), a incorporação de espelhos traseiros e de assentos giratórios apresentou consideráveis reduções das necessidades de giro para trás na operação de tratores agrícolas.

Alguns trabalhos têm sido realizados para estudar a ergonomia em máquinas agrícolas. Baeza \& Casabella (1991) desenvolveram um estudo para avaliar a ergonomia da cabine de comando de colhedoras de cana-de-açúcar em Cuba, analisando o ajuste dimensional da mesma às características do operador, às condições de visibilidade e vias de acesso à cabine. 
Fontana et al. (2004) realizaram uma avaliação ergonômica nos postos de operação entre quatro colhedoras combinadas de grãos de diferentes potências, concluindo que na avaliação espacial a colhedora NH TC 57 apresentou o maior número de comandos dentro da área de ótimo e máximo acesso, sendo também a colhedora melhor avaliada pelos operadores.

Rozin (2004) comparou a ergonometria dos postos de operação de tratores agrícolas nacionais conforme as especificações padronizadas por normas de ergonomia e segurança. Compuseram o universo amostral os tratores agrícolas de rodas com bitola externa superior a 1150 mm, em comercialização no território nacional. Concluiu que as classes compostas por tratores com maior potência no motor apresentaram um maior número de comandos de operação dentro do alcance do braço no plano longitudinal vertical e horizontal.

Silva (2002) realizou uma avaliação ergonômica das máquinas utilizadas nas operações de colheita florestal, avaliando um "feller-buncher", um "skidder" e uma "garra traçadora". As máquinas foram avaliadas de acordo com o manual "Ergonomic Guidelines for Forest Machines", do SkogForsk, concluindo que o "feller-buncher" obteve uma classificação geral, que significa um trabalho altamente produtivo, apresentando ainda um alto grau de segurança ativa e passiva. Foi também verificado que há necessidade de algum ajuste das condições do espaço de trabalho ao operador brasileiro, em função de suas características antropométricas serem diferentes dos europeus, para os quais a máquina foi desenhada.

Fiedler (1995) desenvolveu uma pesquisa em oito máquinas de colheita de madeira no sistema de árvores inteiras, concluindo que o acesso mais difícil foi o do "feller-buncher" de tesouras Implanor Bell e do carregador florestal MJ 10070. Quanto às dimensões dos postos de trabalho, o carregador florestal Motocana e o mini "skidder" tiveram as maiores distorções. Quanto às dimensões do assento, o traçador mecânico Caterpillar foi o que apresentou valores mais próximos daqueles indicados pela metodologia desenvolvida. Em 
todas as máquinas, o nível de ruído estava acima do permitido pela legislação brasileira de atividades e operações insalubres (NR 15) e as máquinas com níveis de ruído mais altos foram o "feller-buncher" (106 dBA) e o "skidder" (101 dBA). As máquinas com visibilidade dificultada foram, principalmente, o carregador florestal MJ10070 e o "feller-buncher". Os controles e instrumentos que estavam mais bem posicionados eram os dos traçadores mecânicos. Nos carregadores florestais Motocana e MJ3047 e no mini "skidder", os gases de exaustão freqüentemente atingiam o operador. As máquinas em piores situações em relação às avaliações subjetivas de vibração eram o "fellerbuncher", o carregador florestal MJ3047 e o mini "skidder".

Lima (1998) realizou a avaliação ergonômica nos tratores florestais "feller-buncher" (411EX Hidro-Ax) e "skidder" (CAT 525), com o objetivo de avaliar as dimensões de acesso, assento, comandos, campo visual, condições térmicas, vibração, nível de ruído e inclinação que permite a estabilidade longitudinal e transversal para o tráfego, concluindo que o "skidder" teve seu acesso ao posto do operador classificado como bom e o "feller-buncher" como médio. O assento nas duas máquinas foi considerado como bom na avaliação qualitativa. Para o posto do operador o "skidder" teve melhor classificação, comparando o espaço livre de 55,0\% contra 30,0\% do "feller-buncher". Quanto ao nível de ruído o "skidder" apresentou um valor de 83 dBA e o "feller-buncher" 89 dBA, sendo que o valor permitido pela legislação brasileira é de 85 dBA para uma exposição continua durante 8 horas.

Yamashita (2002) avaliou a exposição do operador à vibração emitida pelas máquinas "harvester" (CAT 320BL), "slingshot" (Timberjack S1821), "feller-buncher" (Timberjack H1818) e o "forwarder" (Volvo A25C) em situação de trabalho normal, com a finalidade de discutir os efeitos potenciais da exposição às vibrações de corpo inteiro e às condições de segurança no local de trabalho. A avaliação da exposição à vibração foi realizada com base em normas internacionais e os resultados das avaliações mostraram que algumas máquinas utilizadas na colheita florestal necessitavam de um estudo mais 
aprofundado para a definição da jornada de trabalho, em particular a máquina utilizada para extração de madeira ("forwarder"). Os efeitos nocivos da vibração à saúde humana são notórios, conforme se pode observar nos trabalhos pesquisados, entretanto, uma quantificação precisa dos seus efeitos ainda é discutida, inclusive nas normas internacionais, devido as variáveis de características sinérgicas e de longo prazo que estão relacionadas com outros fatores de riscos presentes na atividade florestal.

\subsection{Condições de Visibilidade (Campo Visual do Operador)}

Para que ocorra uma boa operação agrícola é necessário que o operador tenha uma perfeita visualização de todo o campo de trabalho da máquina. As condições de visibilidade encontradas em uma cabine são outro aspecto muito importante, relacionado com a segurança e produtividade. Segundo Fiedler (1995), há necessidade de uma visualização perfeita de todo o campo de trabalho para operação de máquinas florestais. O campo de visibilidade necessário à operação, segundo Grandjean (1982), deve estar relacionado com a função da máquina, variando de acordo com o ciclo de trabalho.

A visibilidade deve permitir uma direção segura por parte do operador, com perfeito controle sobre o trator e seu implemento e a atividade agrícola executada, como também possibilitar a verificação rápida dos instrumentos visuais, aumentando a segurança na operação e facilitando o manejo e o emprego eficiente do trator (Meirelles, 1976).

Segundo lida (2001), embora o aparelho visual humano forneça informação sensitiva extremamente precisa, o grau de iluminação é muito importante na apreensão do que se vê. O fato de um objeto não estar sendo adequadamente visualizado, pode ser devido a vários fatores tais como tamanho muito pequeno para certas distâncias, iluminação deficiente, contraste inadequado de seus limites, significativa diferença de brilho no campo visual ou ao tempo insuficiente para a sua focalização adequada (Couto, 1987). 
Menezes et al. (1985) avaliaram as características de visibilidade de um grupo de tratores de rodas nacionais e determinaram a relação entre as áreas de projeção dos tratores e as áreas de visibilidade nula ao nível do solo. Concluíram que em todas as condições estudadas, o trator Agrale 4100 foi o trator que proporcionou melhor visibilidade, devido ao seu porte pequeno e a altura elevada do assento em relação ao capô.

No advento dos tratores agrícolas, os projetos estavam voltados para a sua utilização e redução dos seus custos de produção. Com o passar do tempo e o uso de novas tecnologias, passou-se a buscar o aperfeiçoamento da relação homem-máquina, com a finalidade de aumentar a sua produtividade em melhores condições de trabalho.

Do ponto de vista ergonômico, um dos itens que devem ser previstos no projeto de uma máquina, é o campo visual. Suas características são importantes para que o operador obtenha rápida percepção das operações a serem realizadas, além de não influenciar na postura de seu corpo durante a jornada de trabalho. Durante seu trabalho o operador fica exposto a condições adversas vindas do ambiente e da máquina, sendo estas decorrentes do projeto da máquina (Menezes et al., 1985).

A visibilidade do operador não pode sofrer interferência por vidros embaçados, pequenos e mal distribuídos, ou estar obstruída por telas estreitas, braços e mangueiras hidráulicas e pelo acionador do limpador de pára-brisas (Fiedler, 1995).

Segundo Couto (1987) a fadiga visual do operador está relacionada com a visibilidade ineficiente causada por obstáculos, dificultando a percepção de um determinado objeto.

Este problema é tratado por Márquez (1997), o qual recomenda que os elementos estruturais laterais formem um ângulo reto com a direção de visão do operador e que a sua largura seja a menor possível. A visão necessária das rodas dianteiras e equipamentos dianteiros obriga a utilização de transparências nas partes mais baixas da cabine e espelhos de tamanho 
suficiente, para evitar posturas incômodas e antifisiológicas, do mesmo modo que para controlar os implementos traseiros.

Dessa maneira, Zander (1972) apud Menezes et al. (1985), dividiu o campo visual em três regiões distintas, correspondendo a ângulos de visão de $50^{\circ}, 170^{\circ}$ e $300^{\circ}$, cujos valores estão diretamente ligados ao tempo de reação do operador. Esta divisão foi adotada por Menezes et al. (1985) e cada campo visual definido como demonstrado na Figura 1.

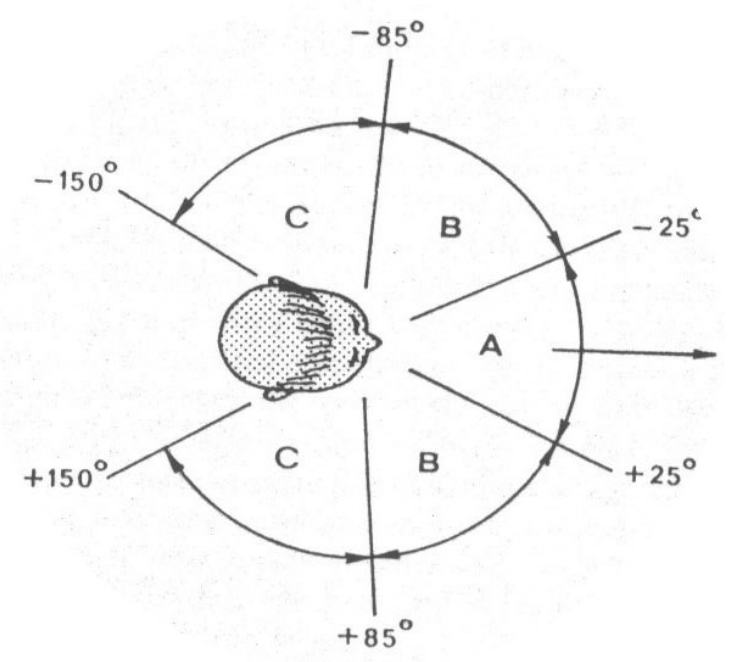

Figura 1 - Campos visuais do operador: A - campo visual estacionário; B campo visual dos olhos e C - campo visual obtido com o movimento da cabeça

Fonte: Menezes et al. (1985).

O campo visual estacionário $(A)$ é aquele coberto pela visão periférica, com a percepção de detalhes sendo reduzida à periferia, com sensibilidade para detectar objetos em movimento. No campo visual (B) são necessários movimentos dos olhos para complementar a visão periférica. Por outro lado, o campo visual (C) obtido com o movimento da cabeça requer um tempo de reação mínima.

Por outro lado, a visibilidade dos comandos e dos instrumentos marcadores (mostrador de pressão de óleo, por exemplo) também precisa ser 
muito boa. Por isso, estes devem estar dentro do campo de visão do operador, colocando-se os mais importantes, ou seja, os mais utilizados, centrados à frente do operador e, nas laterais, os menos utilizados. As luzes desses instrumentos devem ter um brilho suficiente para que sejam vistas inclusive em condições ambientais de maior luminosidade (lida, 2001). Assim, na Figura 2 pode-se observar os campos visual ótima e máxima visão dos operadores quanto aos instrumentos, luzes de advertência e mostradores.

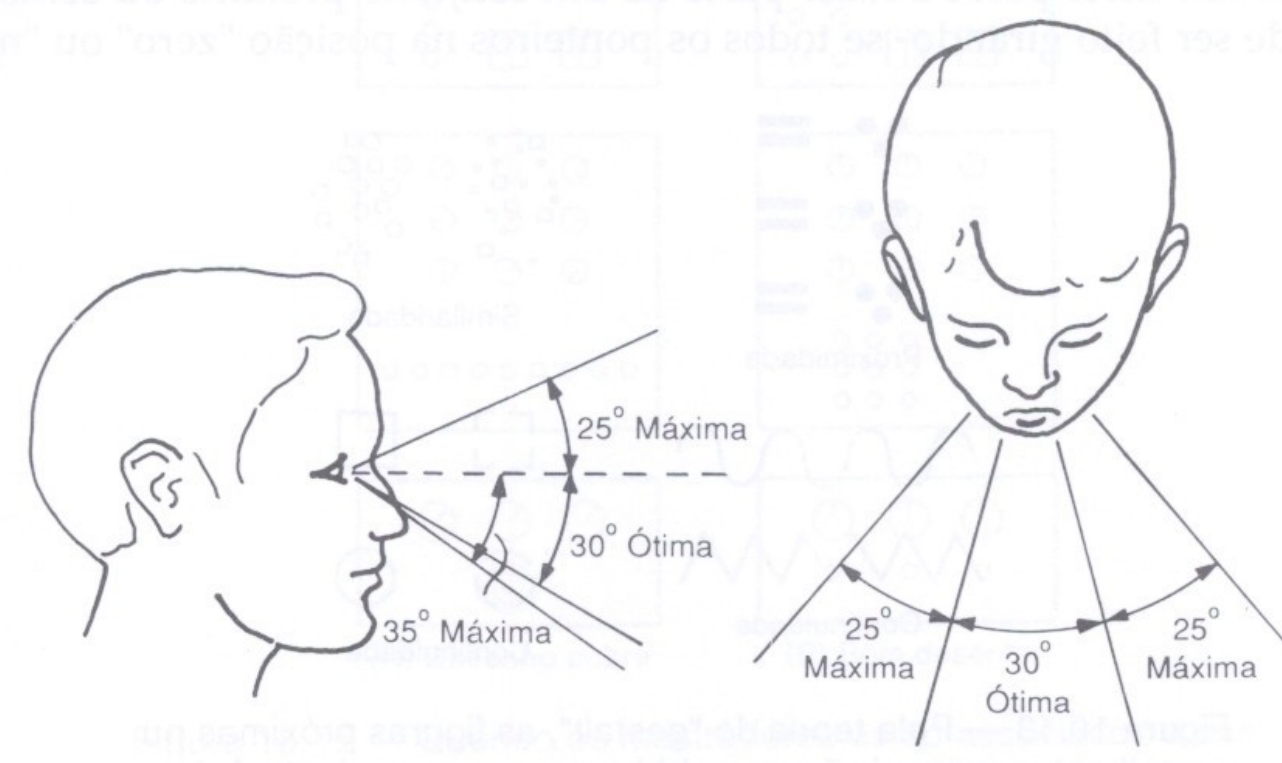

Figura 2 - Áreas de visão ótima e máxima

Fonte: lida (2001).

Fontana et al. (2004) avaliaram o campo visual dos operadores em colhedoras de grãos, concluindo que as colhedoras apresentaram um excelente campo visual, com alta visibilidade para a região do campo de visão estacionária $(A)$ e o campo visual dos olhos $(B)$.

Menegas (2001) determinou a perda visual do operador de trator agrícola, comparando-se os resultados de dois tratores semelhantes, com e sem cabine. Os resultados obtidos demonstraram que a utilização da cabine 
diminui o campo de visão do operador nos campos B e $C$, concluindo que o campo B é o maior prejudicado, quando o trator possui cabine.

Segundo Zander (1972), as características do campo visual assumem vital importância para que ocorra rápida percepção do operador. A postura do corpo quando este controla uma máquina é influenciada pela visibilidade do trabalho. O aumento do campo visual por meio de movimentos do corpo causa um aumento na carga de trabalho e prejudica o desempenho do operador, à medida que ele adota uma postura inadequada.

De acordo com Chudakov (1977) para que um determinado operador de um trator realize um certo movimento com os comandos, é necessário primeiro a percepção pelos olhos, para depois a reação dos braços ou pernas. 


\section{MATERIAL E MÉTODOS}

\section{1 Áreas de Estudo}

Este trabalho foi desenvolvido com dados levantados em áreas de colheita de madeira em duas empresas florestais, localizadas nos municípios de Mogi Guaçu e Lençóis Paulista, no estado de São Paulo. As jornadas de trabalho nas empresas são de 24 horas, com os "forwarders" e "skidders" operando em três turnos de oito horas, de segunda-feira a sábado.

\subsection{Sistemas de Colheita nas Empresas}

As empresas executam diferentes processos de mecanização da colheita florestal. Na empresa A, a colheita por "toras longas" é realizada por uma frente de trabalho que utiliza o "feller-buncher" para a derrubada, a extração com "skidders" e a toragem com a garra-traçadora (Figura 3). A empresa B emprega um sistema de "toras curtas", com o corte das árvores sendo feito por um "harvester" e a extração por "forwarders" (Figura 4). 

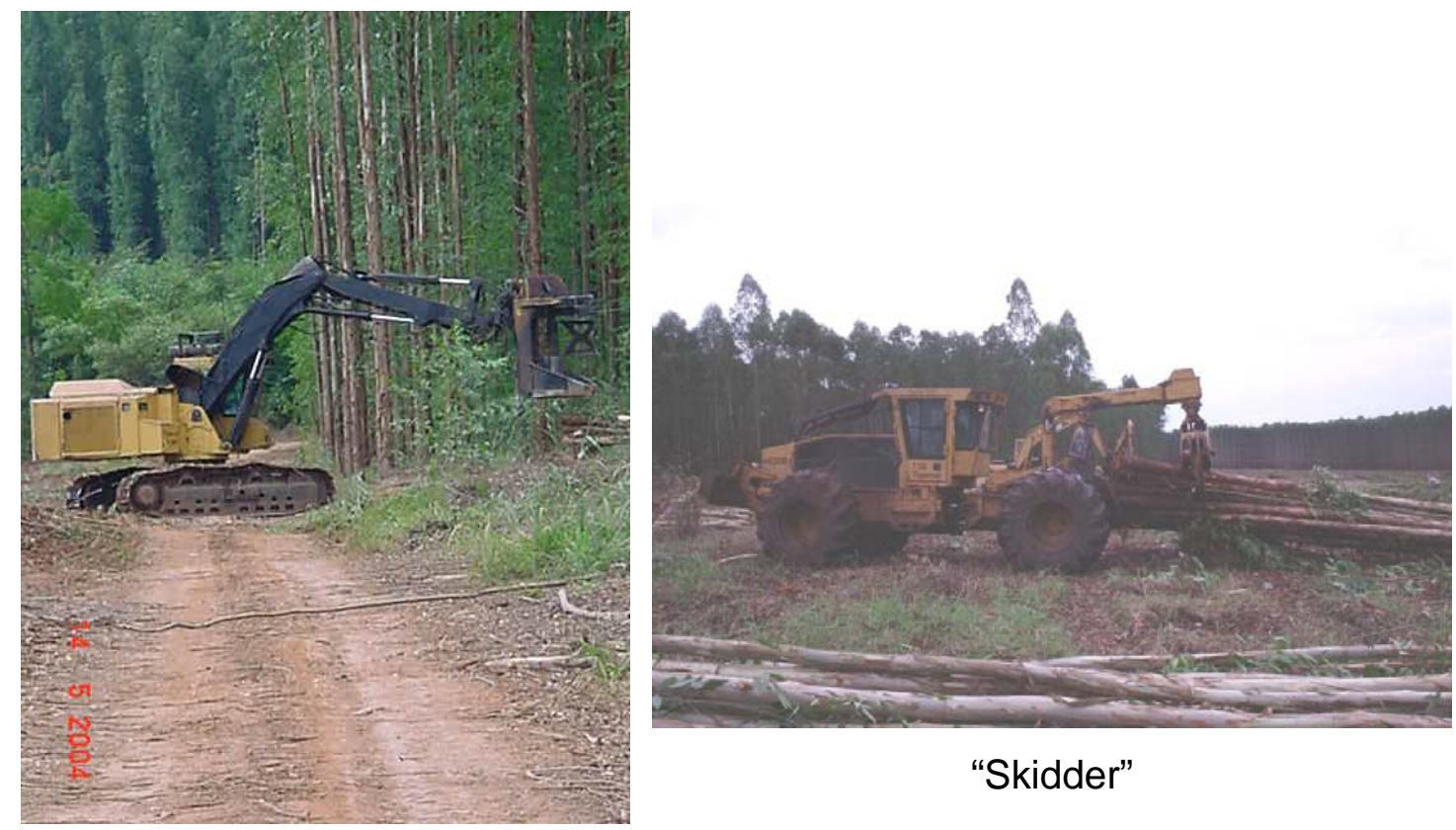

"Skidder"

"Feller-buncher"

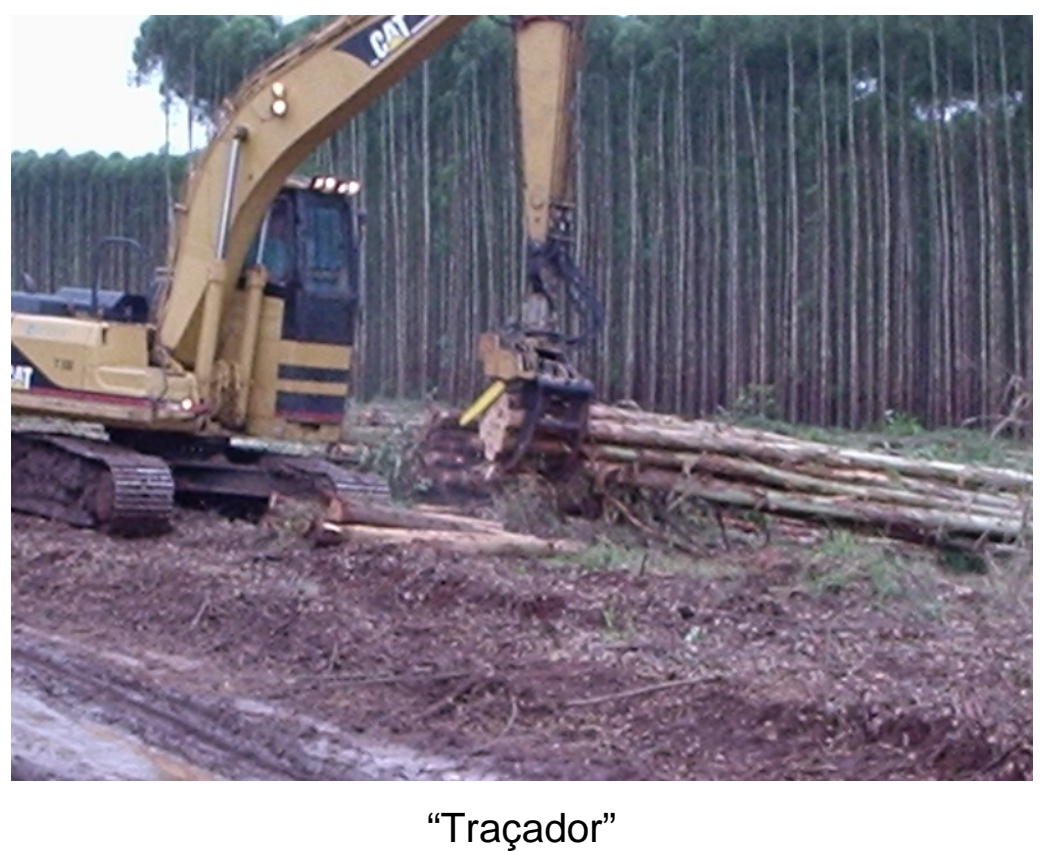

Figura 3 - Máquinas florestais utilizadas no sistema de colheita mecanizado na empresa $A$ 


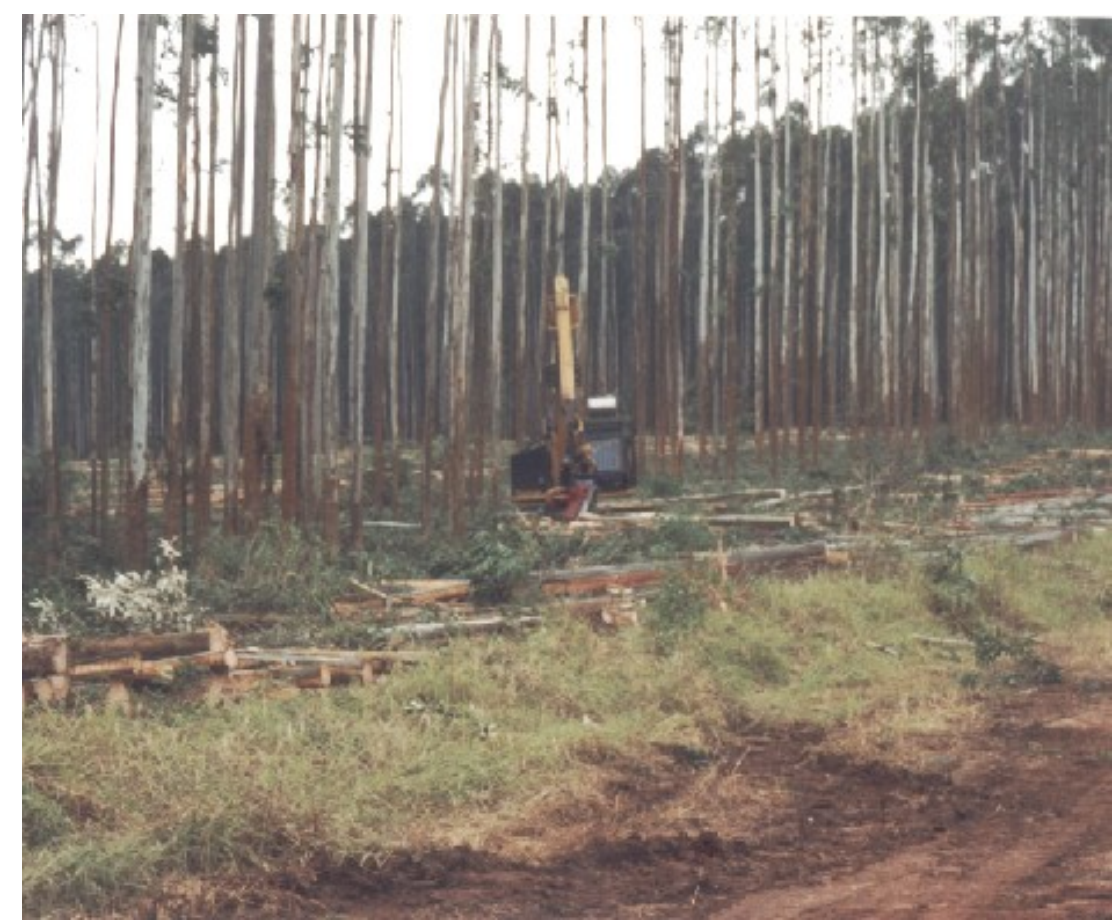

"Harvester"

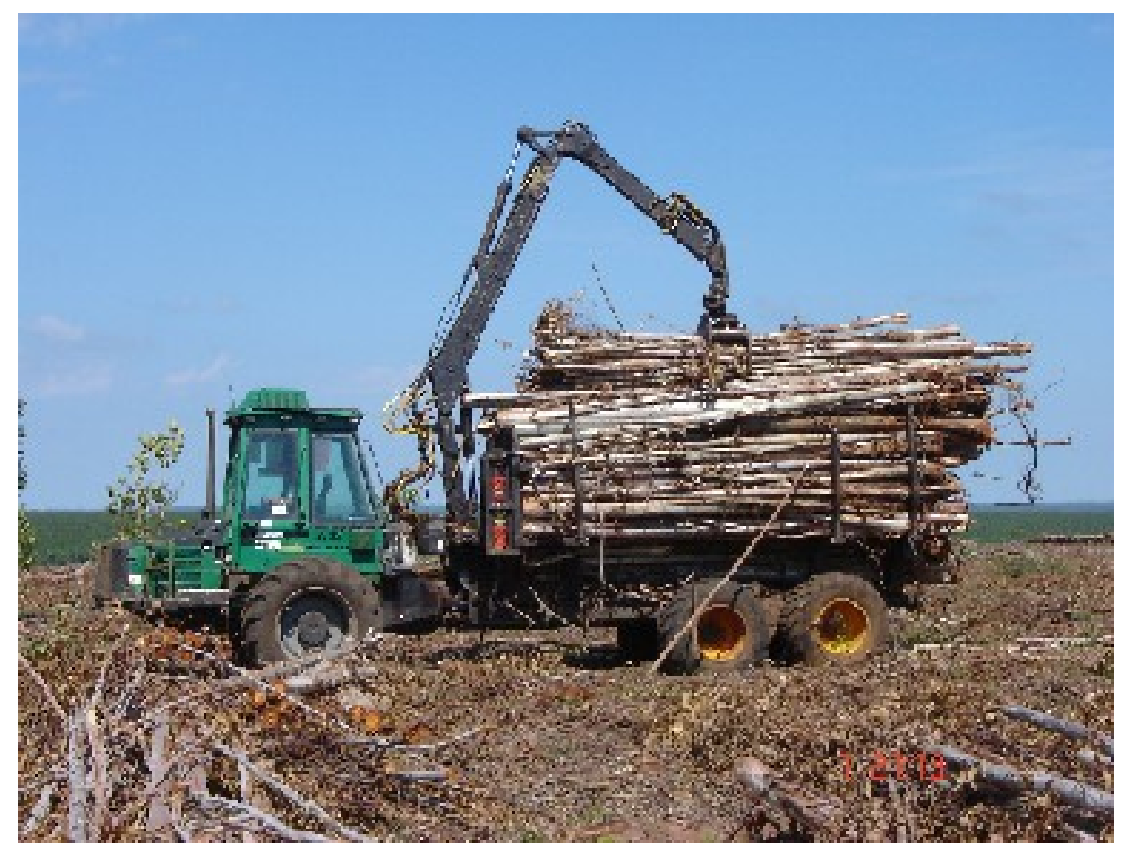

"Forwarder"

Figura 4 - Máquinas florestais utilizadas no sistema de colheita mecanizado na empresa B 


\subsection{Caracterização das Máquinas}

Os "forwarders" utilizados neste trabalho são caracterizados na Tabela 2, enfocando algumas características técnicas. A maior parte das máquinas que realizam a colheita de madeira nas empresas brasileiras são importadas, oriundas de países como Suécia, Canadá, Finlândia e Estados Unidos. Neste trabalho foram utilizados três marcas e quatro modelos de "forwarders" (Figuras $5,6,7$ e 8).

Tabela 2. Características das marcas e modelos de "forwarders"

\begin{tabular}{|c|c|c|c|c|}
\hline \multirow{2}{*}{ Características } & \multicolumn{2}{|c|}{ Timberjack } & \multirow{2}{*}{\begin{tabular}{|l|} 
Valmet \\
890.2
\end{tabular}} & \multirow{2}{*}{$\begin{array}{l}\text { Volvo } \\
\text { A25C }\end{array}$} \\
\hline & $1210 \mathrm{~B}$ & $1710 \mathrm{D}$ & & \\
\hline Potência kW - (cv) & $128-(174)$ & $215-(292)$ & 151- (205) & $190-(258)$ \\
\hline Especificação do Motor & $\begin{array}{l}\text { Perkins } \\
1006\end{array}$ & $\begin{array}{c}\text { John Deere } \\
6018 \mathrm{HT}\end{array}$ & $\begin{array}{c}\text { Valmet } 634 \\
\text { DWIE }\end{array}$ & $\begin{array}{c}\text { Volvo } \\
\text { TD73KCE }\end{array}$ \\
\hline $\mathrm{N}^{\circ}$ de Cilindros & $6^{(*)}$ & $6^{(*)}$ & $6^{(*)}$ & $6^{(*)}$ \\
\hline $\begin{array}{l}\text { Sistema de } \\
\text { Transmissão }\end{array}$ & Hidrostática & Hidrostática & Hidrostática & Torque \\
\hline Massa $(\mathrm{Kg})$ & 15000 & 17500 & 16800 & 16000 \\
\hline Carga Útil (Kg) & 12000 & 17000 & 18000 & 21000 \\
\hline Comprimento (mm) & 9920 & 10100 & 9708 & 9675 \\
\hline Largura (mm) & 2840 & 2990 & 2995 & 2490 \\
\hline Altura (mm) & 3680 & 3900 & 3970 & 3150 \\
\hline Cabine & Sim & Sim & Sim & Sim \\
\hline Originário & EUA & EUA & Finlândia & Suécia \\
\hline Idade (horas) & 24.979 & 8.023 & 993,0 & 16.432 \\
\hline
\end{tabular}




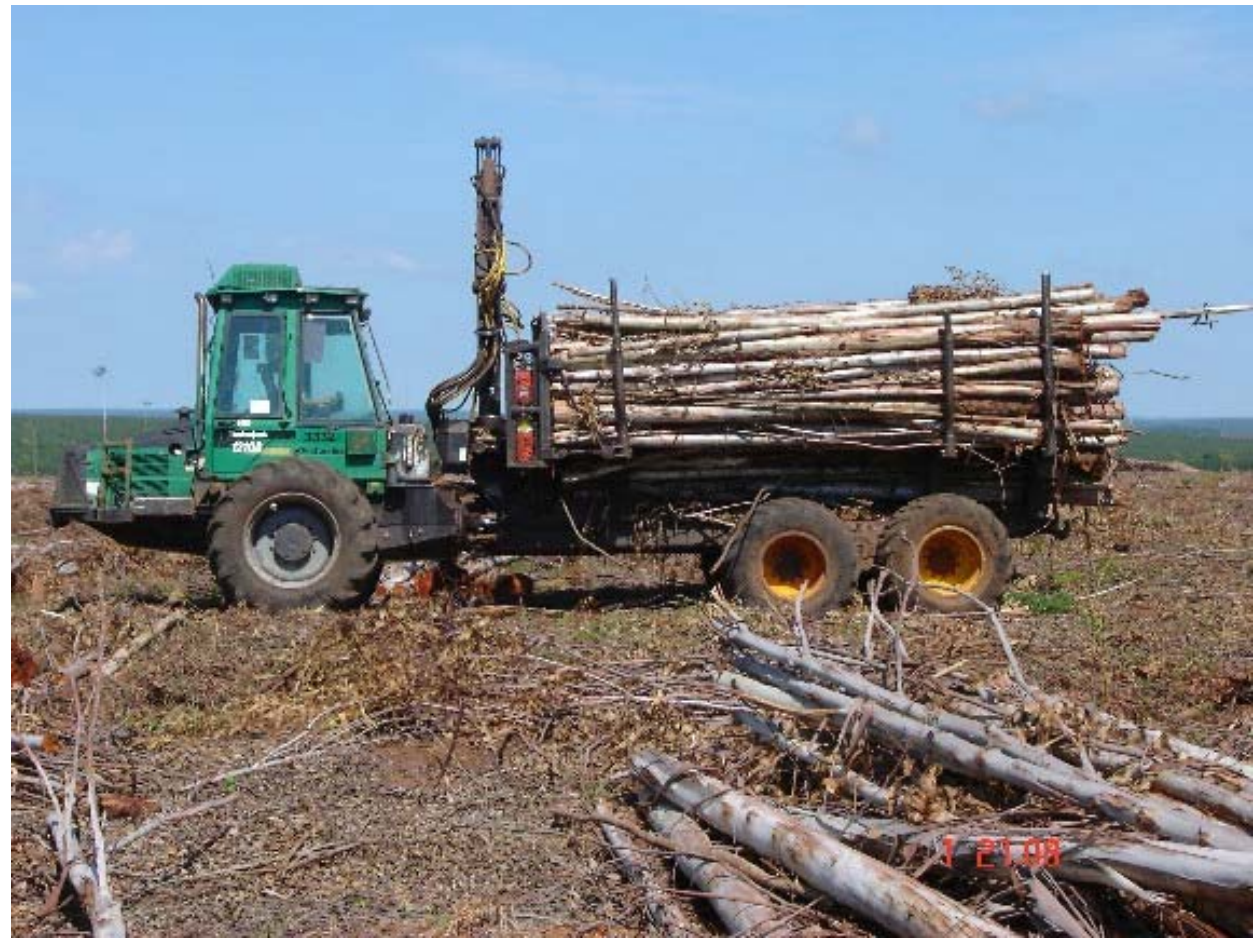

Figura 5 - "Forwarder" Timberjack modelo 1210B

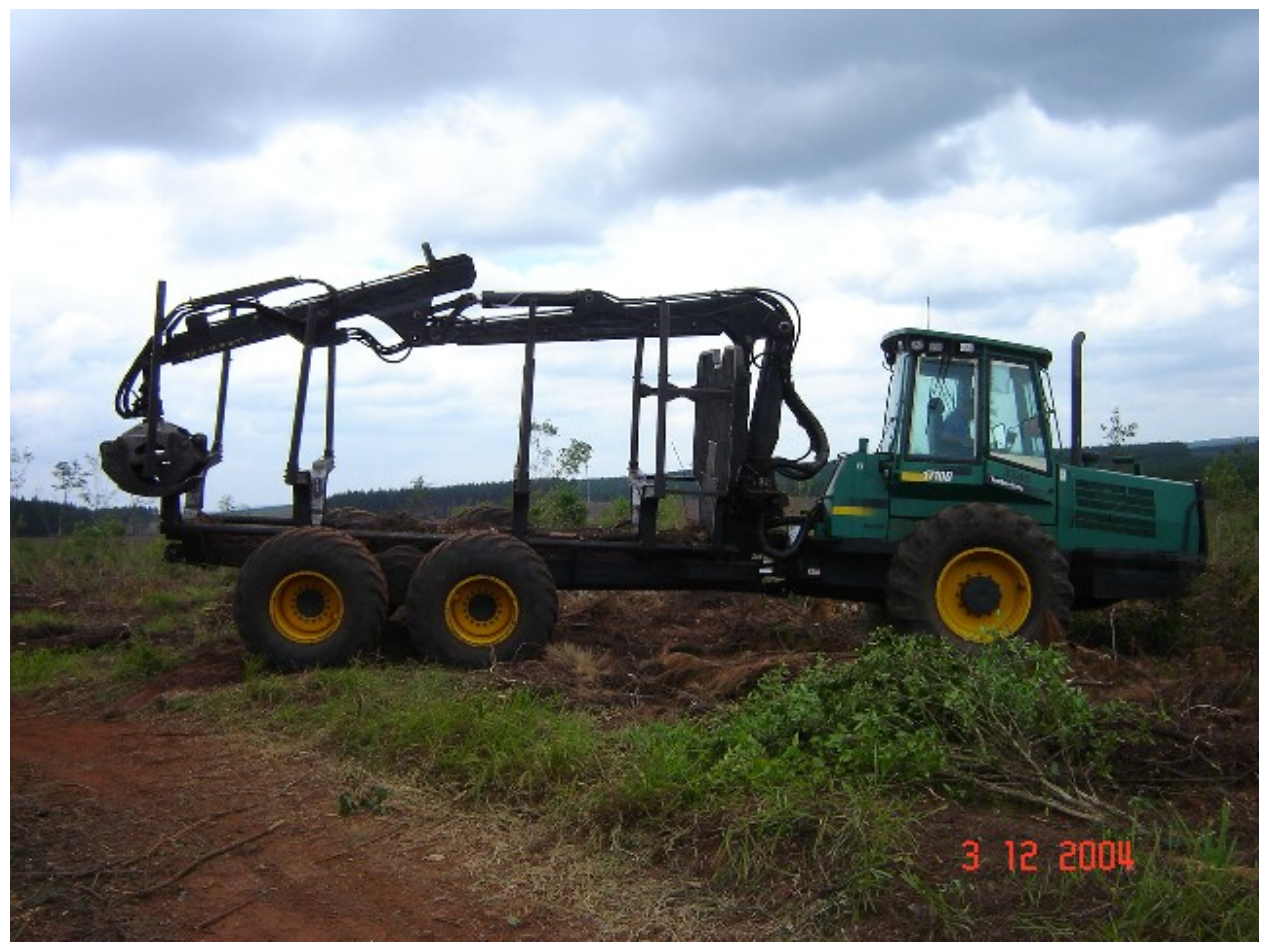

Figura 6 - "Forwarder" Timberjack modelo 1710D 


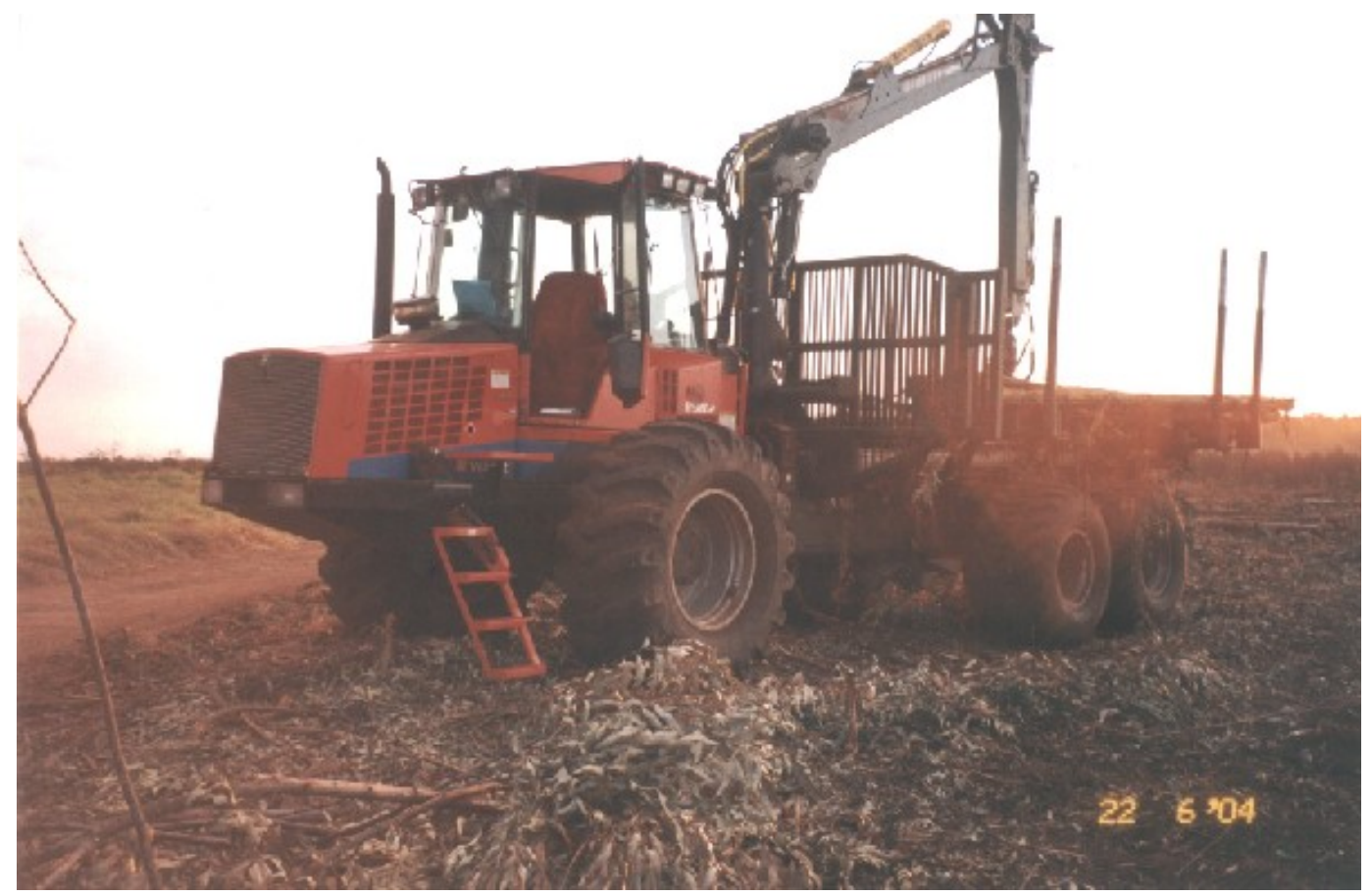

Figura 7 - "Forwarder" Valmet modelo 890.2

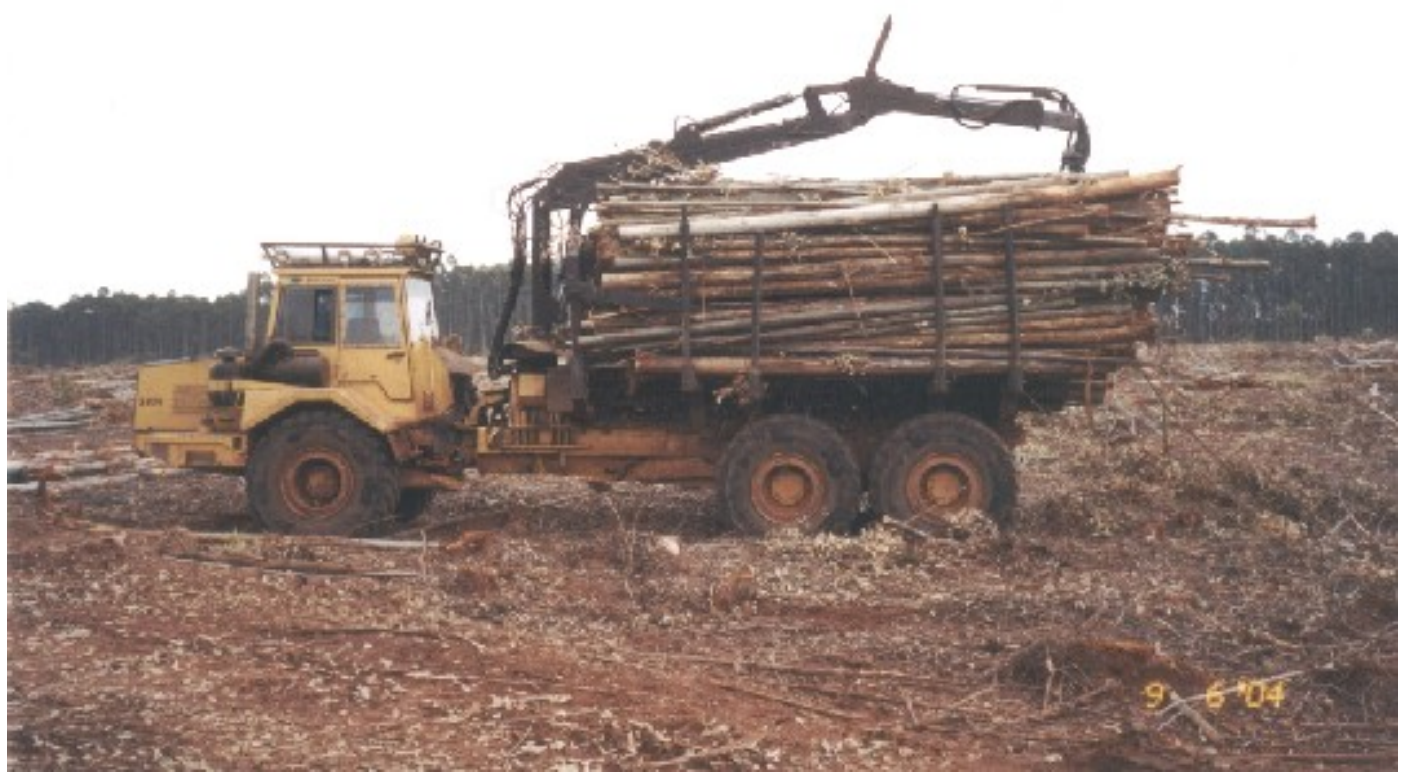

Figura 8 - "Forwarder" Volvo modelo A25C 
Os "skidders" (Figura 9 e 10) avaliados neste trabalho são de dois modelos e marcas diferentes, cujas características são mostradas na Tabela 3.

Tabela 3. Características das marcas e modelos de "skidders"

\begin{tabular}{|c|c|c|}
\hline \multirow{2}{*}{ Características } & Caterpillar & Tigercat \\
\hline & 545 & 630B \\
\hline Potência kW - (cv) & $168-(225)$ & $180-(240)$ \\
\hline Especificação do Motor & 3306 DITA Caterpillar & Cummins 6CTA 8.3 \\
\hline $\mathrm{N}^{\circ}$ de Cilindros & $6^{(*)}$ & $6^{(*)}$ \\
\hline Sistema de Transmissão & Torque & Torque \\
\hline Massa $(\mathrm{Kg})$ & 15445 & 16000 \\
\hline Comprimento (mm) & 7570 & 8280 \\
\hline Largura (mm) & 3217,4 & 3300 \\
\hline Altura (mm) & 3385 & 3150 \\
\hline Cabine & Sim & $\operatorname{Sim}$ \\
\hline Originário & EUA & Canadá \\
\hline Idade (horas) & 9.565 & 9.754 \\
\hline
\end{tabular}




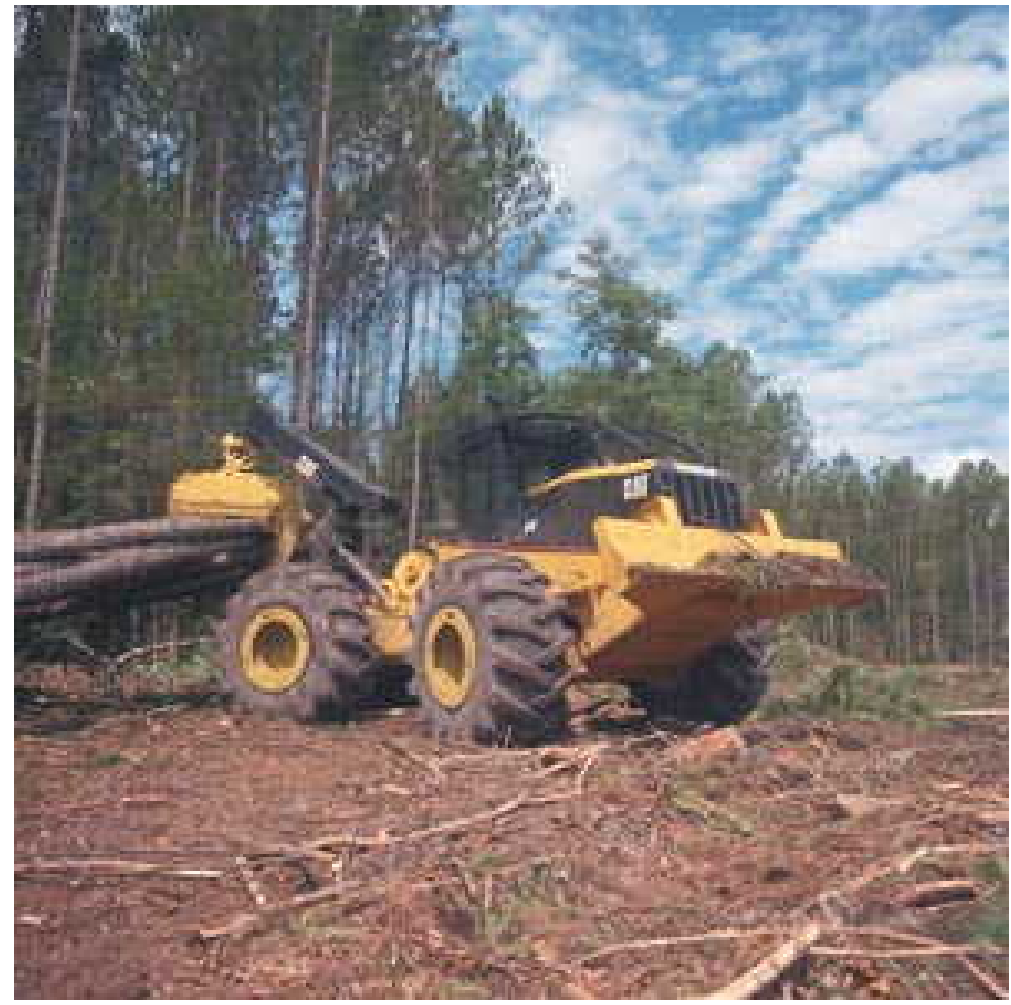

Figura 9 - "Skidder" Caterpillar modelo 545

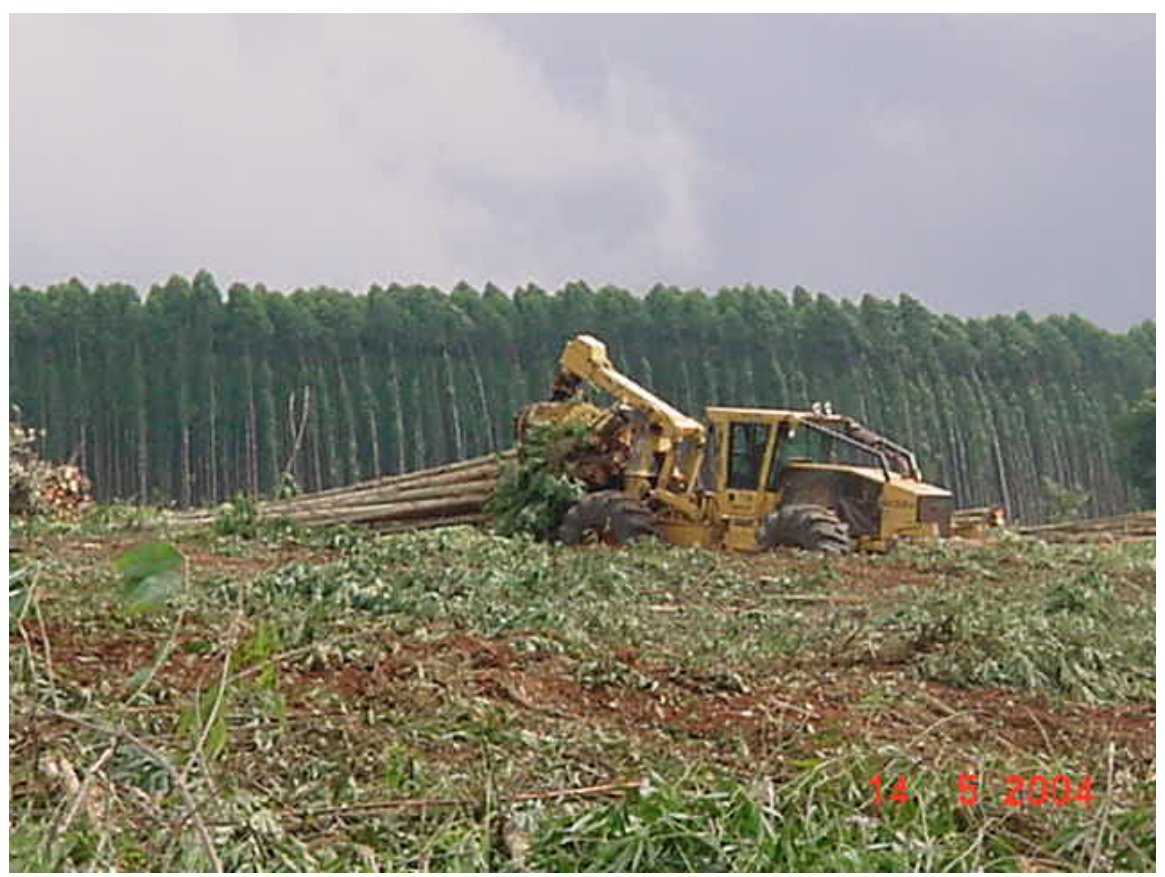

Figura 10 - "Skidder" Tigercat modelo 630B 


\subsection{Avaliação Ergonômica}

\subsubsection{Dispositivo para Simulação do Ponto de Referência do Assento (SIP)}

A avaliação ergonômica dos "forwarders" e "skidders" foi realizada por meio de medidas a partir do ponto de referência do assento (SIP - "Seat Index Point”), que de acordo com a norma NBR NM-ISO 5353 (Associação...,1999), é um ponto situado no plano médio longitudinal central do assento, onde o plano tangencial do encosto intersecciona um plano horizontal.

Para determinação do ponto de referência do assento (SIP) foi utilizado um dispositivo em madeira de lei (Figura 11), seguindo as orientações da NBR NM-ISO 5353 (Associação...,1999). Para minimizar o atrito entre o dispositivo e o assento das máquinas avaliadas, utilizou-se um tecido de percal e, em seguida, adicionou-se progressivamente massas retangulares de $10 \mathrm{~kg}$ até se atingir $65 \mathrm{~kg}$, o que adicionado à massa do dispositivo, representa a massa de $75 \mathrm{~kg}$, considerada como sendo a média dos operadores brasileiros.

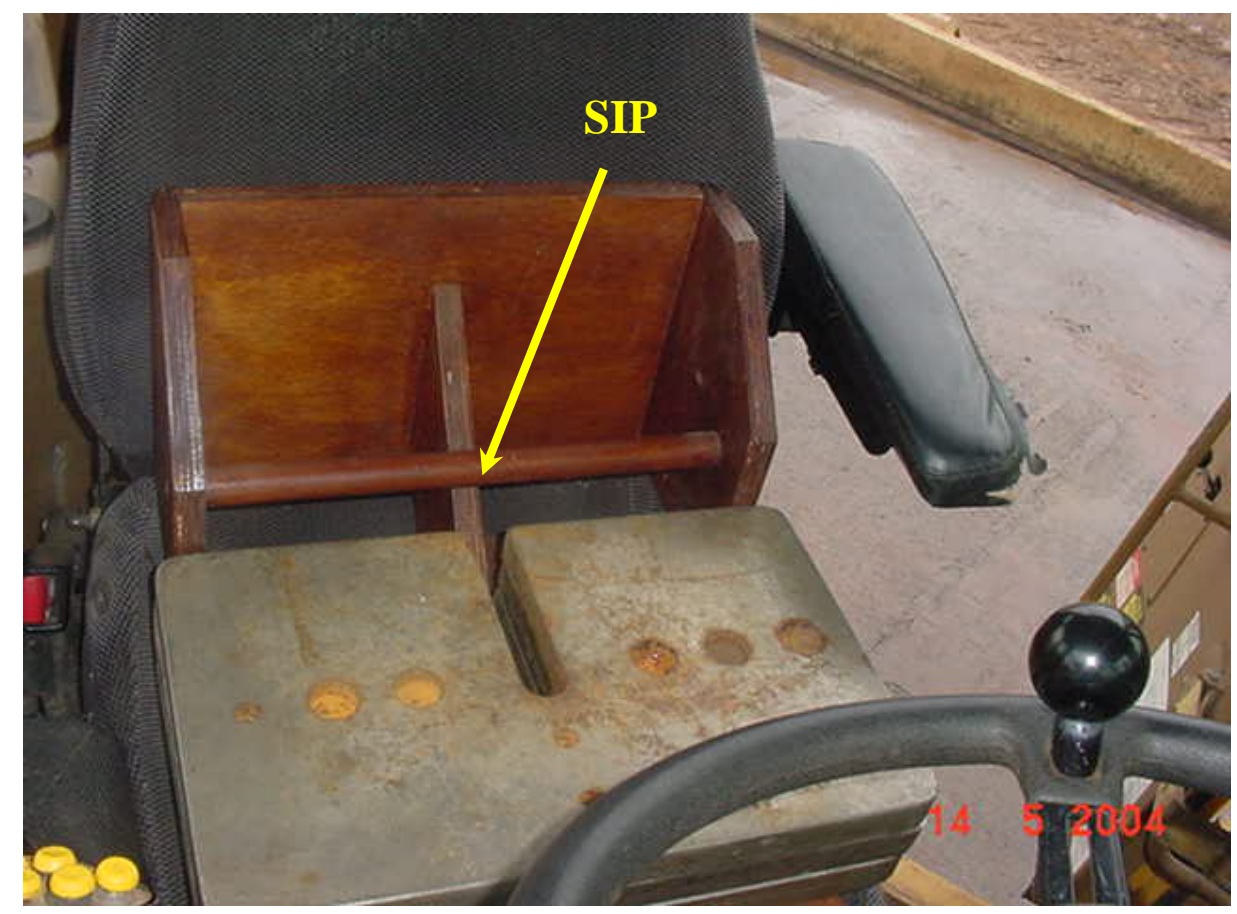

Figura 11 - Dispositivo para simulação do SIP 


\subsubsection{Determinação das Dimensões do Projeto Interno (Avaliação Ergonométrica)}

Para a determinação ergonômica do projeto interno da cabine, as medidas foram coletadas com o auxilio de um equipamento de medida semelhante ao desenvolvido por Zander (1972) (Figura 12), onde se mensurou as distâncias do SIP até os órgãos de comando nas três dimensões (x, y e z) e posteriormente representadas em um gráfico contendo as áreas de máximo e ótimo acesso aos comandos, esquematizados de acordo com as características antropométricas de um grupo de operadores brasileiros (Figura 13). O equipamento é composto por uma base de ferro maciça, que recebe uma das duas hastes reguláveis ligadas por uma junção. Ambas as hastes são graduadas em centímetros.

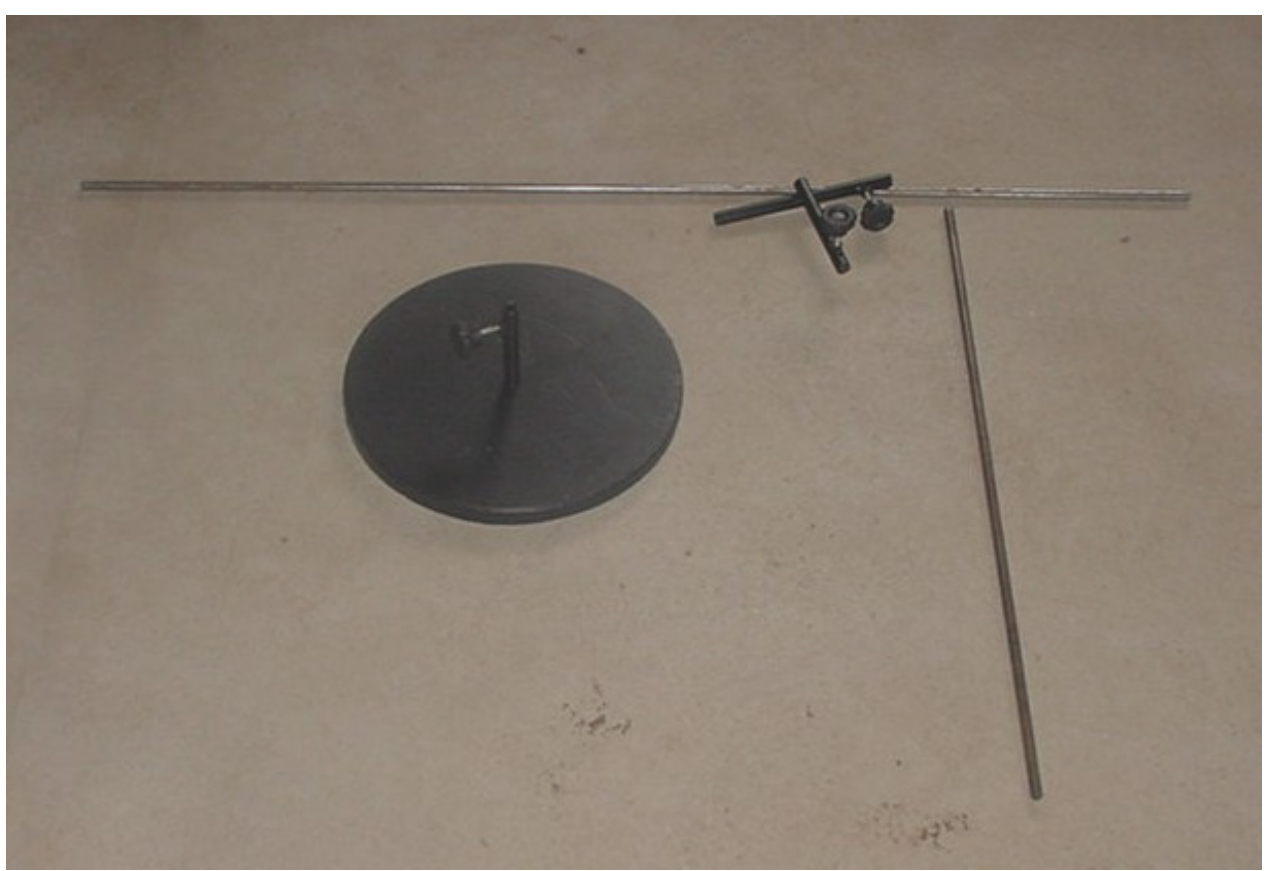

Figura 12 - Equipamento de medidas do SIP aos órgãos de comando

Para esta avaliação ergonômica foram coletados os dados com o assento em três posições distintas, classificadas como limites: próximo, médio e extremo, adotado-se como referência o painel das máquinas em estudo. Desta 
maneira foi realizada a avaliação espacial da distribuição dos comandos para as três posições do assento, atribuindo conceitos conforme classificação na Tabela 4.

Tabela 4. Conceitos da avaliação espacial dos comandos nas coordenadas $x-y$ e $x-z$

\section{Conceito Descrição}

Ótimo Comando situado na região de ótimo acesso nos dois planos.

Muito bom Comando situado na região de ótimo em um plano e de máximo no outro plano.

Bom Comando situado na região de máximo nos dois planos.

Regular Comando situado na região de máximo em um plano e fora no outro plano.

Ruim Comando situado em região externa aos dois planos. 


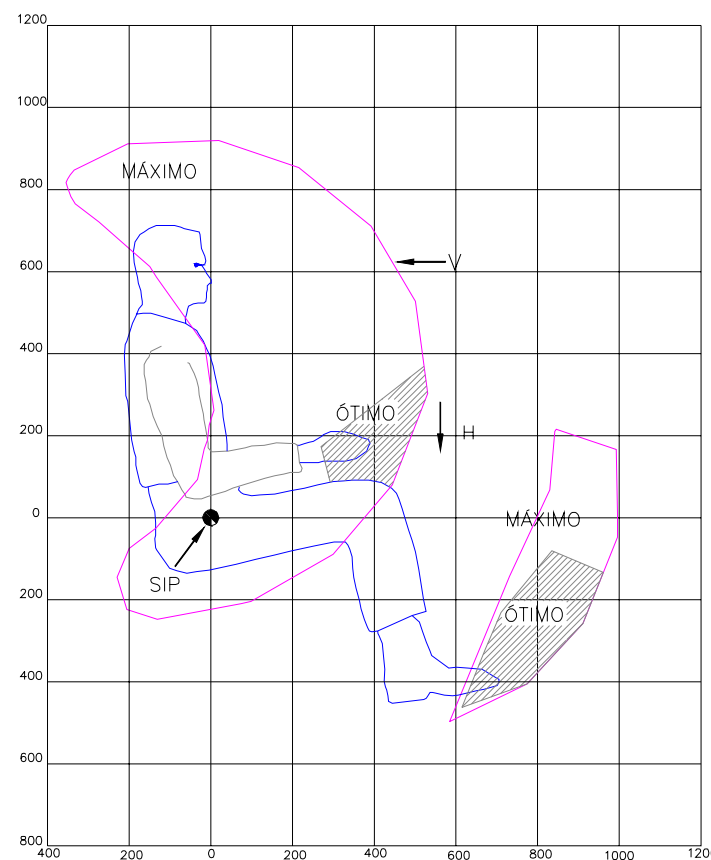

Distância dos comandos em relação ao SIP na direção X (mm)

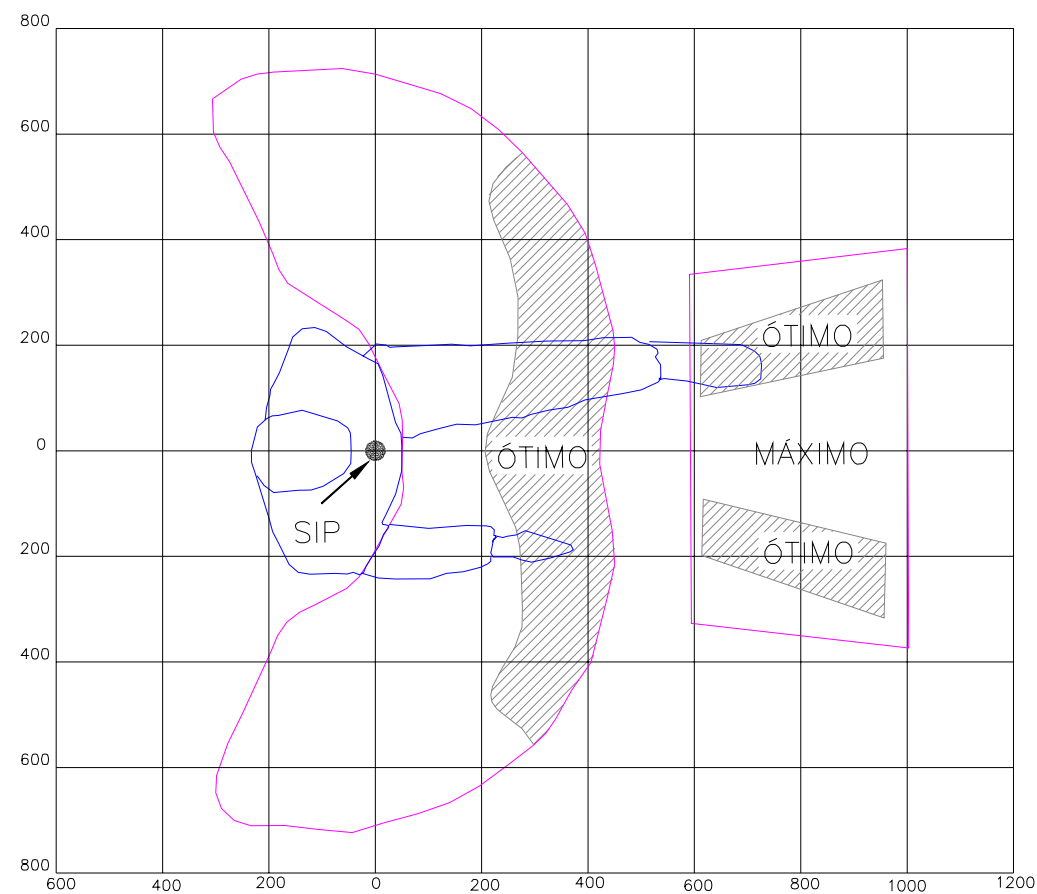

Distância dos comandos em relação ao SIP na direção X $(\mathrm{mm})$

Figura 13 - Áreas de máximo e ótimo acesso aos órgãos de comando, nas três dimensões 


\subsubsection{Dispositivo para Determinação de Medidas Antropométricas}

Para esta avaliação, foram determinadas vinte medidas corporais de 34 operadores, sendo 23 operadores de "forwarders" e 11 de "skidders". Para a obtenção destas medidas, utilizou-se uma cadeira portátil especial, de acordo com o apresentado por Serrano (1996), pertencente à Fundação Jorge Duprat de Segurança e Medicina do Trabalho (FUNDACENTRO), órgão vinculado ao Ministério do Trabalho, cuja precisão é da ordem de centímetros. As medidas foram efetuadas em três etapas distintas relacionadas a seguir.

10: Preenchimento da ficha esquematizada na Figura 14, onde foram registrados os seguintes dados:

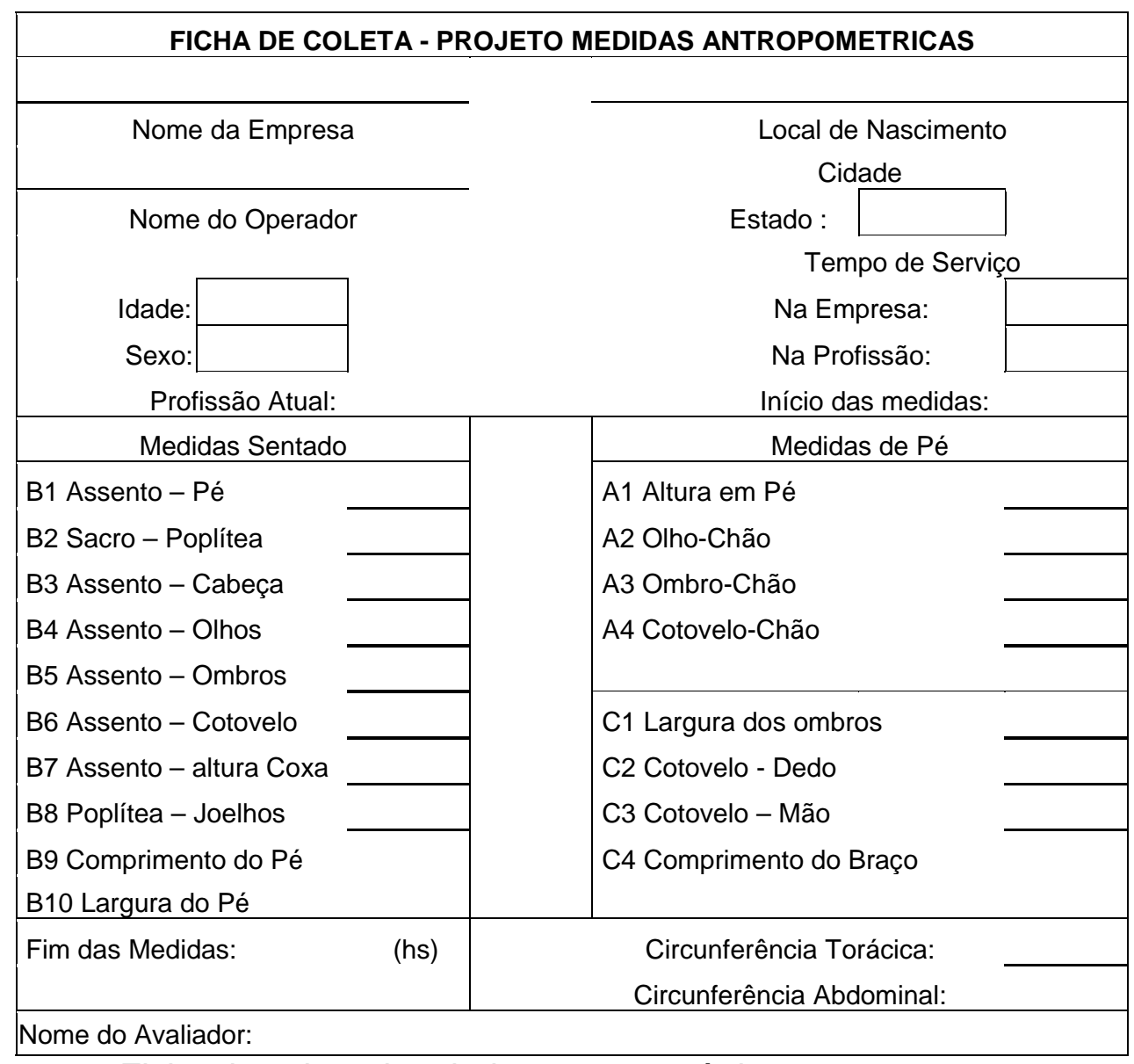

Figura 14 - Ficha de coleta dos dados antropométricos

Fonte: Serrano (1996). 
$2^{\text {o: }}$ As medidas antropométricas na posição em pé, foram obtidas através da escala antropométrica, onde esta escala realiza as medidas 1, 2, 3 e 4. Para as demais medidas antropométricas, utilizou-se de equipamento denominado de antropômetro, que nada mais é que um paquímetro de 1 metro de comprimento. As medidas tomadas estão esquematizadas na Figura 15.

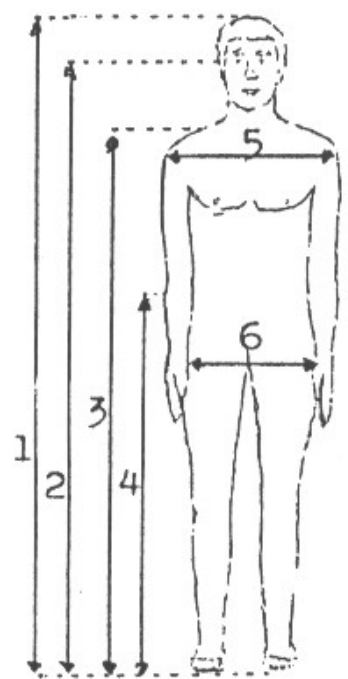

1 - altura em pé

2 - olho - chão

3 - ombro - chão

4 - cotovelo - chão

5 - largura do ombro
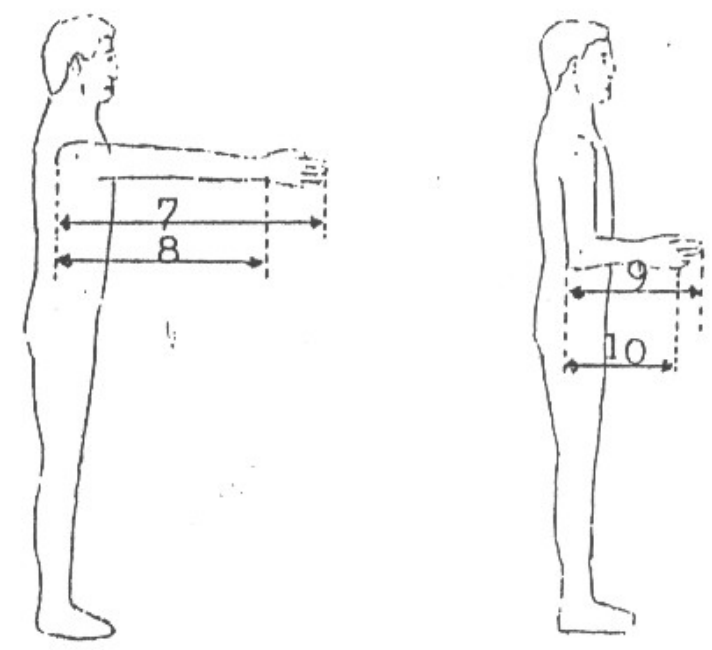

6 - largura do quadril

7 - ombro- extremidade do dedo médio

8 - ombro - punho

9 - cotovelo - extremidade do dedo médio

10 - cotovelo-extremidade da mão fechada

Figura 15 - Medidas tomadas com régua graduada

Fonte: Serrano (1996). 
$3^{\circ}$ : Foram tomadas as dez medidas na posição sentada, utilizando a cadeira portátil especial (Figura 16).

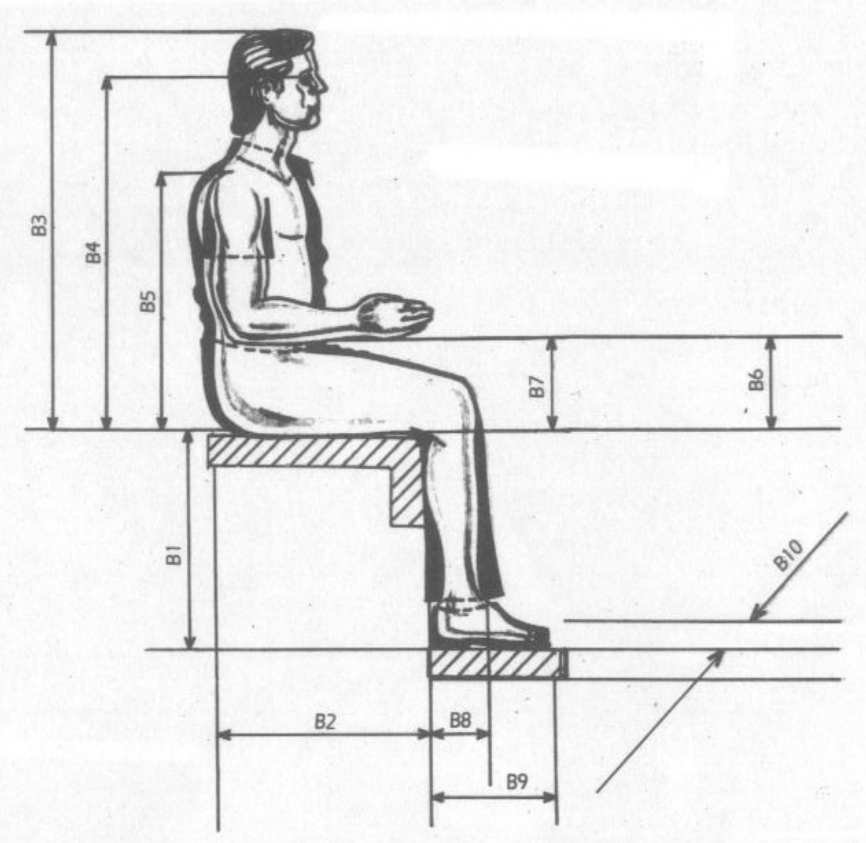

B1 Assento-pé

B2 Sacro - poplítea

B3 Assento - cabeça

B4 Assento - olho

B5 Assento - ombro

B6 Assento - cotovelo

B7 Assento - altura da coxa

B8 Poplitea - extrem. Joelho

B9 Comprimento do pé

B10 Largura do pé

Figura 16 - Cadeira com escalas de medições antropométricas

Fonte: Serrano (1996).

Para determinar as variações antropométricas dos operadores, a análise estatística constou do cálculo dos percentis, nos níveis 5,0, 50,0 e 95,0\%. Também foram determinados a média, o desvio padrão, o coeficiente de variação e o intervalo da medida no qual se encontram $90,0 \%$ dos indivíduos. 0 coeficiente de variação e o intervalo da medida foram utilizados para efeito de comparação com dados antropométricos referentes aos países de origem dos equipamentos florestais. Finalmente, esses valores possibilitaram a determinação gráfica das áreas de máximo e ótimo acesso. 


\subsubsection{Análise do Posicionamento Visual dos Instrumentos}

Para determinar o campo visual ótima e de máxima visão dos operadores quanto ao posicionamento dos instrumentos marcadores (relógios de temperatura de arrefecimento, combustível, pressão de óleo, por exemplo), luzes de advertências e mostradores em geral, foram utilizados procedimentos semelhantes aos descritos no item 3.4.2, onde nesta avaliação foram inseridos os ângulos de visão de ótima e máxima (Figura 2), como o auxilio do "software" AutoCad $2000^{\circledR}$. Desta maneira foi realizado a avaliação espacial da distribuição dos instrumentos marcadores, luzes de advertência e mostradores para as três posições do assento, atribuindo conceitos conforme a classificação na Tabela 5.

Tabela 5. Conceitos da avaliação espacial dos instrumentos de verificação nas coordenadas $x-y$ e $x-z$

\begin{tabular}{|c|c|}
\hline Conceito & Descrição \\
\hline Ótimo & Comando situado na região de ótima visão nos dois planos. \\
\hline Muito bom & $\begin{array}{l}\text { Comando situado na região de ótima em um plano e de máxima } \\
\text { no outro plano. }\end{array}$ \\
\hline Bom & Comando situado na região de máxima nos dois planos. \\
\hline Regular & $\begin{array}{l}\text { Comando situado na região de máxima em um plano e fora no } \\
\text { outro plano. }\end{array}$ \\
\hline Ruim & Comando situado em região externa aos dois planos. \\
\hline
\end{tabular}

\subsubsection{Dispositivo para Determinação da Visibilidade}

Para a determinação da visibilidade foi utilizado o equipamento denominado "Dispositivo GF" (Figura 17). Este dispositivo é constituído de duas hastes reguláveis ligadas por uma junção. Na extremidade superior de uma das hastes é fixada uma lâmpada de vapor mercúrio de 250 watts (23000 Im) e a extremidade da outra haste é fixada ao volante das máquinas por meio de uma braçadeira especial, construída nas dimensões $40 \times 50 \times 30$ mm. A braçadeira é 
fixada ao volante por quatro parafusos de $6 \mathrm{~mm}$, sendo o volante envolvido com couro para evitar danos. Quando a máquina em estudo não possuia volante como é o caso dos "forwarders" da marca Timberjack, o Dispositivo "GF" foi acoplado em uma das hastes do equipamento de medidas (Figura 12), modificado para que pudesse então receber a haste regulável e que o filamento estivesse na altura correta para a obtenção dos efeitos desejados.

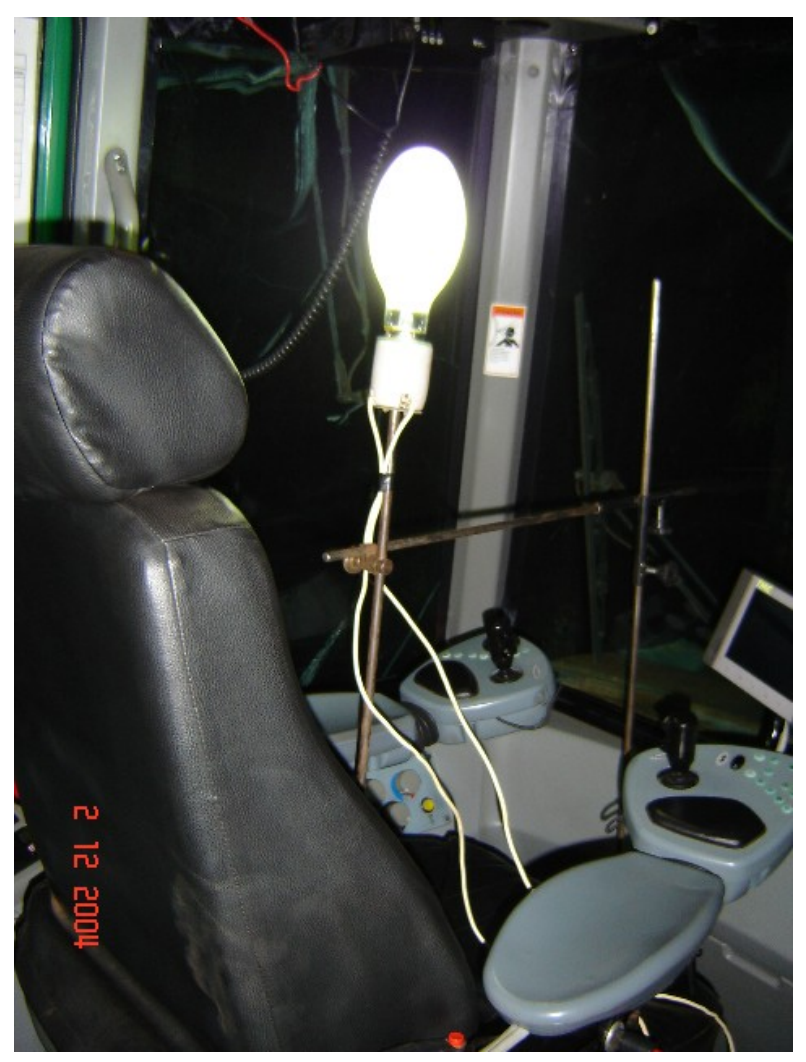

Figura 17 - Dispositivo "GF" para determinação da visibilidade

\subsubsection{Campo Visual do Operador}

A avaliação do campo visual foi realizada por meio do modelo proposto por Menezes et al. (1985), adaptado para as condições de aquisição dos dados dos tratores em estudo, considerando-se os três campos visuais: A - campo visual estacionário; B - campo visual dos olhos; e C - campo visual obtido com o movimento da cabeça (Figura 1). 
Com base naquele modelo e após colocar sobre o assento dos tratores florestais em estudo as massas cilíndricas totalizando $75 \mathrm{~kg}$, foi instalado 0 Dispositivo "GF", sendo posteriormente ajustado para que o filamento da lâmpada ficasse $760 \mathrm{~mm}$ acima do assento, simulando a altura dos olhos do operador (Fontana et al., 2004).

Para determinar as regiões sombreadas dos "forwarders" e "skidders", delimitou-se uma área de 20 x 20 metros, de acordo com a norma ISO 5721 (International..., 1981), onde as máquinas foram colocadas, e demarcadas as áreas de visibilidade com a utilização de bandeiras, adotando-se a origem das medidas a partir do SIP.

As sombras dos "forwarders" e "skidders" foram obtidas com o acendimento da lâmpada sobre o assento, estando os tratores no campo em uma área plana e sem a interferência da luz da Lua, pois as empresas não possuíam galpão totalmente escurecido. Para medir o campo visual dos tratores florestais foram utilizados barbantes, bandeiras e uma trena graduada em centímetros (Figuras 18 e 19), sendo a sombra demarcada e medida com a trena. Os procedimentos foram repetidos para cada máquina em estudo. As sombras demarcadas originaram croquis que no escritório foram desenhados com o auxilio do "software" AutoCad $2000^{\circledR}$.

As áreas das regiões sombreadas, que corresponderam às áreas de visibilidade nula (Avn), e as áreas de projeção dos campos visuais (Acv) foram determinadas também com auxílio do "software" AutoCad $2000^{\circledR}$. 

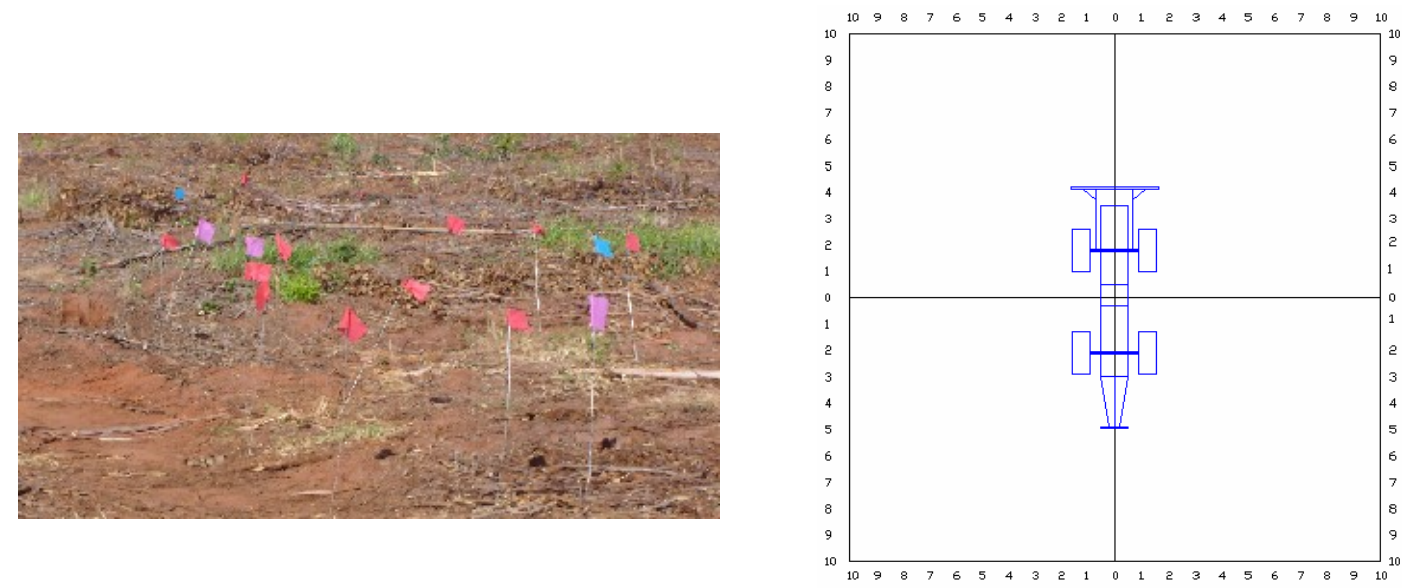

Figura 18 - Área do teste de visibilidade dos "skidders"
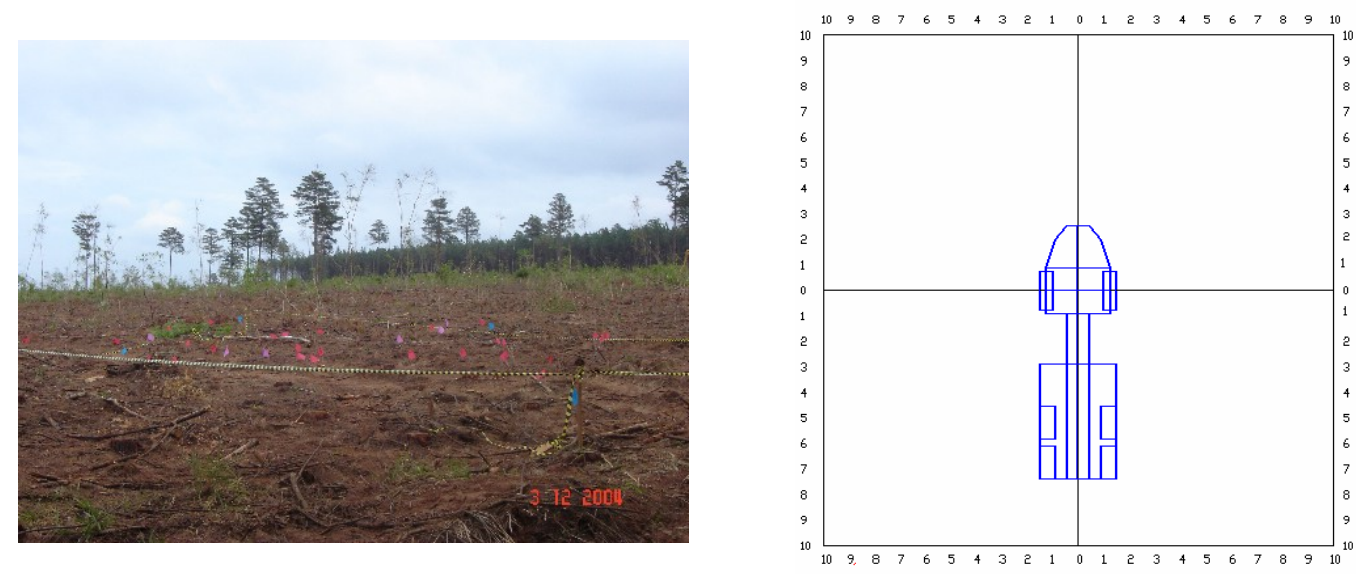

Figura 19 - Área do teste de visibilidade dos "forwarders"

\subsubsection{Avaliação do Questionário}

Além da avaliação ergonômica, aplicou-se um questionário para conhecer a opinião dos operadores sobre o acesso às máquinas, regime de trabalho e a facilidade de execução dos comandos, dentre outros fatores (Figura 20). Neste questionário os operadores atribuíram valores de 1 a 10, em ordem crescente de avaliação, onde o maior valor indica uma avaliação ótima e o menor valor um pior resultado. O questionário foi aplicado a 25 operadores de "forwarders", com idade média de 31,5 anos e com 3,7 anos de experiência, sendo 6 operadores do "forwarder" 1210B, 3 operadores de "forwarder" 1710D, 3 operadores do "forwarder" Valmet 890.2 e 13 operadores do "forwarder" Volvo 
A25C. Foram avaliados 11 operadores de "skidders", com idade média de 38,4 anos e com 8,7 anos de experiência, sendo 7 operadores do Tigercat 630B e 4 operadores do Caterpillar 545.

Para os resultados obtidos foram calculadas as médias dos valores atribuídos pelos operadores a cada item e para cada máquina florestal em estudo. O objetivo deste questionário foi confrontar as regiões de ótimo acesso determinadas na avaliação ergonômica com a opinião dos operadores, pois na maioria das vezes os operadores acompanharam a evolução da maquinaria florestal.

\begin{tabular}{|l|c|c|c|c|c|}
\hline \multicolumn{1}{|c|}{ Marca: Modelo: } \\
OPERADOR:
\end{tabular}

Figura 20 - Modelo da ficha para avaliação do acesso aos órgãos de comando dos operadores de "forwarders" e "skidders" (SkogForsk,1999) 


\section{RESULTADOS E DISCUSSÕES}

\subsection{Antropometria}

Os resultados antropométricos obtidos na amostragem de 34 operadores de máquinas florestais são apresentados na Tabela 6.

Tabela 6. Padrão antropométrico dos operadores de máquinas florestais das empresas em estudo

\begin{tabular}{|c|c|c|c|c|c|c|c|}
\hline \multirow{2}{*}{\multicolumn{2}{|c|}{ Medidas }} & \multirow{2}{*}{$\begin{array}{l}\text { Média } \\
\text { (cm) }\end{array}$} & \multirow{2}{*}{$\begin{array}{l}\text { Desvio } \\
\text { Padrão }\end{array}$} & \multirow{2}{*}{$\begin{array}{l}\text { CV } \\
(\%)\end{array}$} & \multicolumn{3}{|c|}{ Percentil } \\
\hline & & & & & $5 \%$ & $50 \%$ & $95 \%$ \\
\hline A1 & Altura em pé & 170,7 & 0,06 & 4,0 & 159,9 & 168,0 & 181,4 \\
\hline $\mathrm{A} 2$ & Altura olho-chão & 160,2 & 0,05 & 3,0 & 149,9 & 157,0 & 170,4 \\
\hline A3 & Altura ombro-chão & 144,1 & 0,05 & 3,0 & 135,8 & 141,5 & 152,3 \\
\hline A4 & Altura cotovelho-chão & 106,5 & 0,04 & 4,0 & 101,9 & 106,0 & 111,1 \\
\hline B1 & Assento-pé & 45,7 & 0,03 & 7,0 & 44,4 & 45,5 & 47,0 \\
\hline B2 & Sacro-poplítea & 48,4 & 0,04 & 8,0 & 46,4 & 47,5 & 50,3 \\
\hline B3 & Assento-cabeça & 84,7 & 0,04 & 5,0 & 81,1 & 84,0 & 88,2 \\
\hline B4 & Assento-olho & 73,9 & 0,05 & 7,0 & 70,2 & 73,0 & 77,5 \\
\hline B5 & Assento-ombro & 61,5 & 0,04 & 7,0 & 58,8 & 61,0 & 64,2 \\
\hline B6 & Assento-cotovelo & 20,7 & 0,02 & 10,0 & 20,0 & 20,1 & 21,3 \\
\hline B7 & Assento-altura da coxa & 15,2 & 0,02 & 13,0 & 14,9 & 15,0 & 15,5 \\
\hline B8 & Poplítea-extrem. joelho & 11,9 & 0,02 & 17,0 & 11,5 & 11,7 & 12,1 \\
\hline B9 & Comprimento do pé & 25,4 & 0,01 & 4,0 & 25,0 & 25,1 & 25,8 \\
\hline B10 & Largura do pé & 9,8 & 0,01 & 10,0 & 9,5 & 9,7 & 9,9 \\
\hline C1 & Largura dos ombros & 47,3 & 0,03 & 6,0 & 45,7 & 46,5 & 48,9 \\
\hline $\mathrm{C} 2$ & $\begin{array}{l}\text { Cotovelo extremidade do dedo } \\
\text { indicador }\end{array}$ & 47,4 & 0,02 & 4,0 & 46,4 & 46,5 & 48,3 \\
\hline C3 & $\begin{array}{l}\text { Cotovelo extremidade da mão } \\
\text { fechada }\end{array}$ & 39,4 & 0,02 & 5,0 & 38,6 & 39,0 & 40,2 \\
\hline $\mathrm{C} 4$ & Comprimento do braço & 85,2 & 0,05 & 6,0 & 80,8 & 83,5 & 89,7 \\
\hline & Massa & 85,2 & 0,08 & 9,0 & 77,0 & 83,0 & 93,5 \\
\hline
\end{tabular}


Quando comparados os dados antropométricos dos operadores de máquinas florestais das empresas em estudo com os operadores do Sul dos Estados Unidos, os resultados demonstram que há diferenças com o biótipo geral dos operadores da região abrangida por esta pesquisa (Tabela 7).

Tabela 7. Comparação do padrão antropométrico entre os operadores de máquinas florestais dos EUA ${ }^{(*)}$ e das empresas em estudo

\begin{tabular}{|c|c|c|c|c|c|c|}
\hline \multirow{2}{*}{\multicolumn{2}{|c|}{ Medidas }} & \multicolumn{2}{|c|}{$E A^{(*)}$} & \multicolumn{2}{|c|}{ Estudo } & \multirow[b]{2}{*}{$\Delta \%$} \\
\hline & & $\begin{array}{l}\text { Média } \\
\text { (cm) }\end{array}$ & $\begin{array}{c}\text { Intervalo } \\
90,0 \% \\
\end{array}$ & $\begin{array}{l}\text { Média } \\
(\mathrm{cm})\end{array}$ & $\begin{array}{c}\text { Intervalo } \\
90,0 \% \\
\end{array}$ & \\
\hline A1 & Altura em pé & 179,3 & $169,8-188,8$ & 170,7 & $159,9-181,4$ & $-4,8$ \\
\hline A2 & Altura olho-chão & ------- & ------------- & 160,2 & $149,9-170,4$ & ------ \\
\hline A3 & Altura ombro-chão & ------- & -------------- & 144,1 & $135,8-152,3$ & ------ \\
\hline A4 & Altura cotovelho-chão & -------- & --------------- & 106,5 & $101,9-111,1$ & ------- \\
\hline B1 & Assento-pé & 46,8 & $43,2-50,5$ & 45,7 & $44,4-47,0$ & $-2,4$ \\
\hline B2 & Sacro-poplítea & 49,9 & $44,8-55,01$ & 48,4 & $46,4-50,3$ & $-3,0$ \\
\hline B3 & Assento-cabeça & 89,3 & $78,8-99,7$ & 84,7 & $81,1-88,2$ & $-5,2$ \\
\hline B4 & Assento-olho & 75,7 & $64,6-86,9$ & 73,9 & $70,2-77,5$ & $-2,4$ \\
\hline B5 & Assento-ombro & 61,6 & $56,2-67,0$ & 61,5 & $58,8-64,2$ & $-0,2$ \\
\hline B6 & Assento-cotovelo & 22,3 & $15,8-18,9$ & 20,7 & $20,1-21,3$ & $-7,2$ \\
\hline B7 & Assento-altura da coxa & -------- & ---------------- & 15,2 & $14,9-15,5$ & ------- \\
\hline B8 & Poplítea-extrem. joelho & 12,6 & $12,1-13,1$ & 11,9 & $11,7-12,1$ & $-5,6$ \\
\hline B9 & Comprimento do pé & 30,4 & $28,4-32,4$ & 25,4 & $25,1-25,8$ & $-16,4$ \\
\hline B10 & Largura do pé & 10,9 & $9,8-12,01$ & 9,8 & $9,7-9,9$ & $-10,1$ \\
\hline C1 & Largura dos ombros & 47,7 & $40,3-55,01$ & 47,3 & $45,7-48,9$ & $-0,8$ \\
\hline $\mathrm{C} 2$ & $\begin{array}{l}\text { Cotovelo extremidade do dedo } \\
\text { indicador }\end{array}$ & 50,1 & $46,5-53,7$ & 47,4 & $46,4-48,3$ & $-5,4$ \\
\hline C3 & $\begin{array}{l}\text { Cotovelo extremidade da } \\
\text { mão fechada }\end{array}$ & 38,6 & $35,3-41,9$ & 39,4 & $38,6-40,2$ & 2,1 \\
\hline \multirow[t]{2}{*}{ C4 } & Comprimento do braço & 95,1 & $88,5-101,7$ & 85,2 & $80,8-89,7$ & $-10,4$ \\
\hline & Massa & 89,8 & $60,3-119,3$ & 85,2 & $77,0-93,5$ & $-5,1$ \\
\hline
\end{tabular}

$\Delta \%$ : diferença percentual em relação aos dados antropométricos dos EUA.

Adotou-se os padrões antropométricos americanos (Thomas et al., 2001) como a referência para a comparação com as médias da população dos operadores brasileiros. As maiores diferenças ocorreram para o comprimento 
do pé $(-16,4 \%)$, comprimento do braço $(-10,4 \%)$, largura do pé $(-10,1 \%)$ e para o assento-cotovelo (-7,2\%). A única medida para a qual os operadores brasileiros obtiveram valor maior foi para a medida do cotovelo até a extremidade da mão fechada, variação de 2,1\%.

O comprimento e a largura do pé podem resultar em problemas de acesso e segurança quando algumas máquinas não atenderem as dimensões ideais dos degraus de acesso, sendo estreitos e rasos. O alcance do braço e da mão interfere diretamente no posicionamento dos controles operados pelas mãos. Para que os controles de acionamento freqüente ("joysticks") possam ser considerados bem localizados no sentido horizontal, eles devem estar posicionados dentro da área de alcance normal, que é delimitada pelo semicírculo de raio igual ao alcance da mão (Figura 13). Já os controles acionados de maneira esporádica devem estar dentro da área de alcance máximo. Esta é delimitada pelo semicírculo de raio igual ao alcance do braço. Conforme já foram expostos anteriormente, os operadores medidos nesta pesquisa apresentaram medidas menores para o alcance do braço e da mão que os operadores americanos.

O posicionamento vertical dos comandos é definido também em função do comprimento do braço. Eles devem estar localizados de forma que o operador consiga alcançá-los sem sair de sua posição normal. A distância vertical máxima do nível do ombro do operador até o comando deve ser igual ao comprimento do braço.

A altura ao nível dos olhos sentado interfere diretamente no campo visual do operador. As diferenças encontradas no perfil antropométrico com relação a esta variável, implicam mudanças no projeto do posto de operação. Isto pode ser justificado pelo fato de que, para um mesmo trator, quanto maior a altura do nível dos olhos do operador em relação à plataforma de operação, melhor é a visibilidade. Assim, o operador analisado nesta pesquisa, para um mesmo trator, terá o campo visual um pouco comprometido, caso este não possua assento com regulagem de altura. Os tratores analisados possuíam 
essas regulagens do assento, assim possibilitando ao operador obter um melhor ajuste de postura e menor fadiga durante a jornada de trabalho.

O apoio do assento, por sua vez, é uma medida que influencia na definição do comprimento do assento do operador. O comprimento do assento deve ser tal que possibilite o acionamento dos pedais de freio e acelerador de maneira rápida e com o mínimo de esforço, sem que o operador tenha que sair de sua posição normal. Caso essa especificidade não seja atendida, o operador terá que sair de sua posição normal de trabalho para poder acionar os controles operados pelos pés, obrigando-se assim a se movimentar com maior freqüência e a tirar o apoio do encosto vertical do assento. Este fato aumentará o nível de fadiga ao qual o operador encontra-se submetido durante a jornada de trabalho (Márquez, 1997).

É importante salientar que os limites inferior e superior que definem o intervalo que abrange 90,0\% dos operadores são, respectivamente, o valor de $5,0 \%$ e $95,0 \%$ percentis (Tabela 6). Dessa forma, os componentes do posto de operação passíveis de regulagem quanto ao posicionamento vertical e horizontal, como o volante de direção, "joysticks" e o banco, devem permitir um maior intervalo de regulagem. 


\subsection{Ergonomia}

\subsection{1 "Forwarder" Timberjack modelo 1210B}

Na Tabela 8 é apresentada a avaliação espacial das coordenadas x-y e $x-z$, dos trinta e cinco $(100,0 \%)$ comandos avaliados nas respectivas posições do assento.

Tabela 8. Distribuição espacial dos trinta e cinco comandos do "forwarder" Timberjack 1210B na avaliação espacial das coordenadas x-y e x-z

\begin{tabular}{lccc}
\hline \multirow{2}{*}{ Conceito } & \multicolumn{3}{c}{ Posicionamento do assento } \\
\cline { 2 - 4 } & Próximo & Médio & Extremo \\
\hline Ótimo & $4(11,5 \%)$ & $4(11,5 \%)$ & $4(11,5 \%)$ \\
Muito Bom & $6(17,0 \%)$ & $6(17,0 \%)$ & ------ \\
Bom & $6(17,0 \%)$ & $7(20,0 \%)$ & $17(48,5 \%)$ \\
Regular & $6(17,0 \%)$ & ------ & $5(14,3 \%)$ \\
Ruim & $13(37,5 \%)$ & $18(51,5 \%)$ & $9(25,7 \%)$ \\
\multicolumn{1}{c}{ Total } & $35(100,0 \%)$ & $35(100,0 \%)$ & $35(100,0 \%)$ \\
\hline
\end{tabular}

Analisando-se a distribuição espacial do posicionamento dos comandos com o assento nas três regiões avaliadas, observa-se que os principais comandos utilizados durante a jornada de trabalho, indiferentemente do posicionamento do assento, receberam o conceito de "ótimo", fato explicado por estarem fixos ao assento da máquina (Figura 21).

Entre os comandos que receberam o conceito classificado como "ótimo", encontram-se os "joysticks" do comando da grua do lado esquerdo e direito, "joystick" volante e o interruptor de direção da máquina. Os pedais de acelerador e o freio receberam o conceito "ruim" nas três situações avaliadas, exigindo um esforço ergonométrico adicional para que o operador consiga manipulá-los. Entretanto, observa-se que, para o posicionamento do assento localizado em "próximo", "médio" e "extremo", existe uma diferença na distribuição dos comandos, quando considera-se a somatória dos conceitos 
"ótimo, "muito bom" e "bom", a maior porcentagem foi obtida com o posicionamento em extremo (60,0\%), fato este explicado pela distribuição dos comandos do lado direito do operador.

Analisando a avaliação espacial do ponto de vista do campo visual, verificou-se que $100,0 \%$ das luzes de advertência, incluindo o monitor ("display"), nas três posições do assento, foram classificadas como "regulares" (Figura 22). 


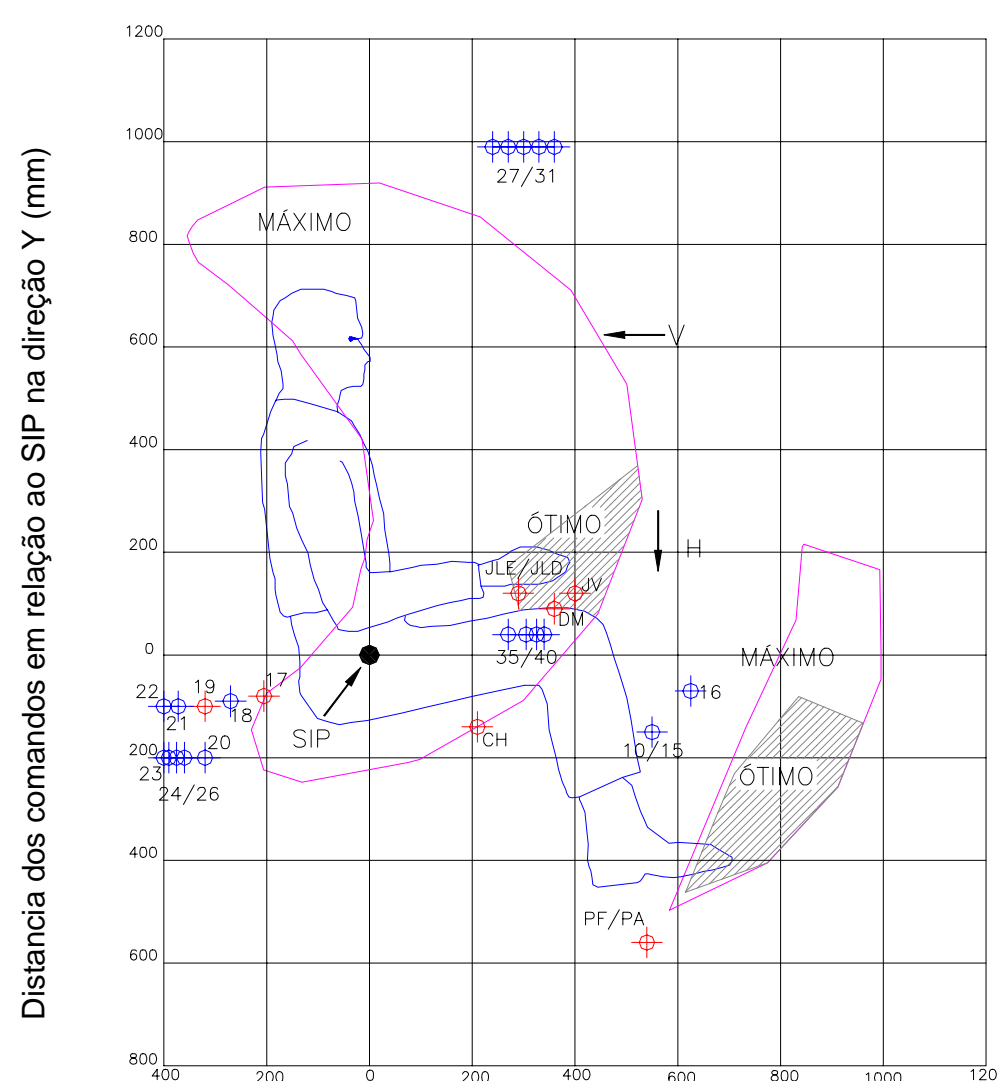

Distancia dos comandos em relação ao SIP na direção X (mm)

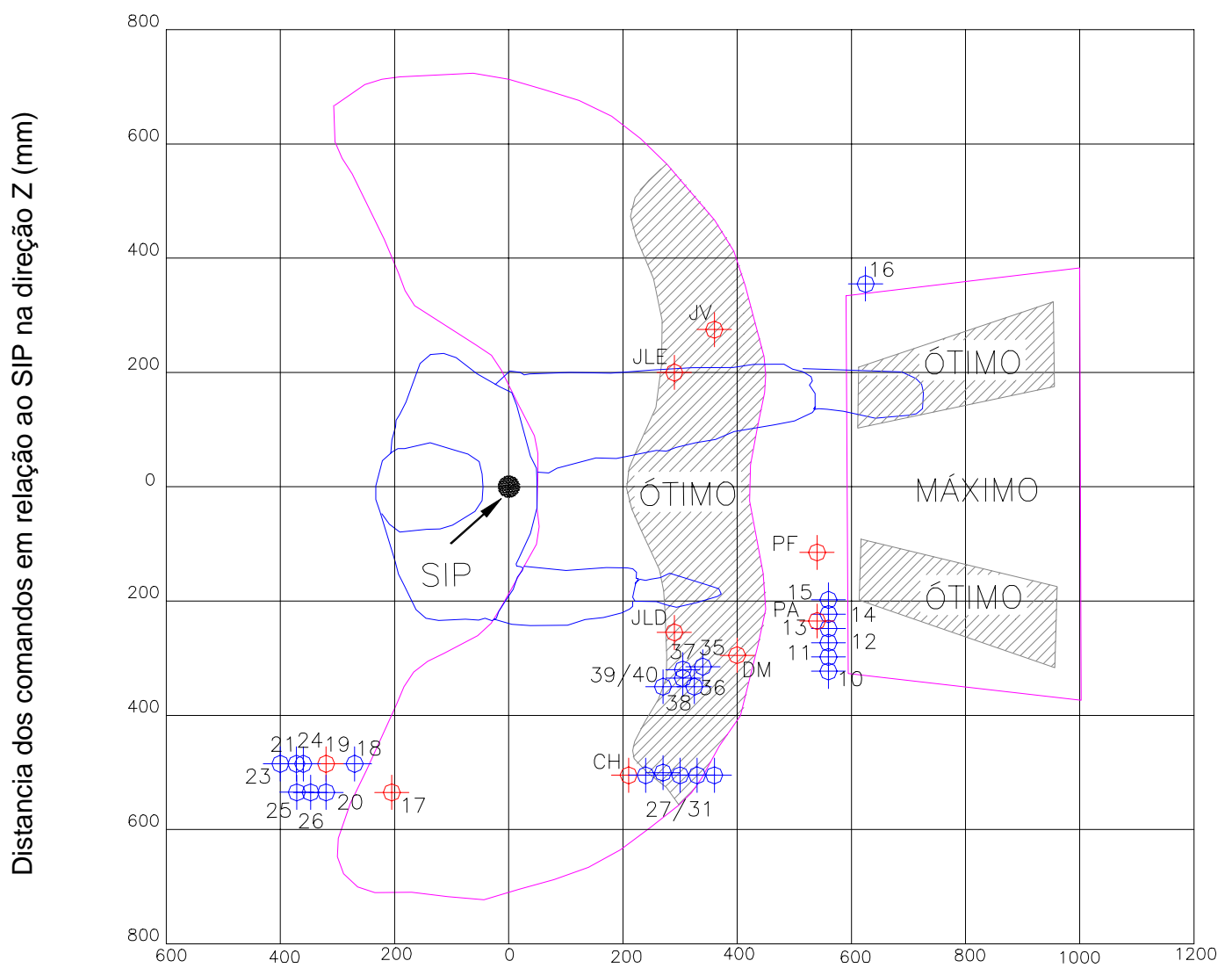

Distancia dos comandos em relação ao SIP na direção X $(\mathrm{mm})$

Figura 21 - Localização dos órgãos de comandos do "forwarder" Timberjack 1210B, nas três dimensões.

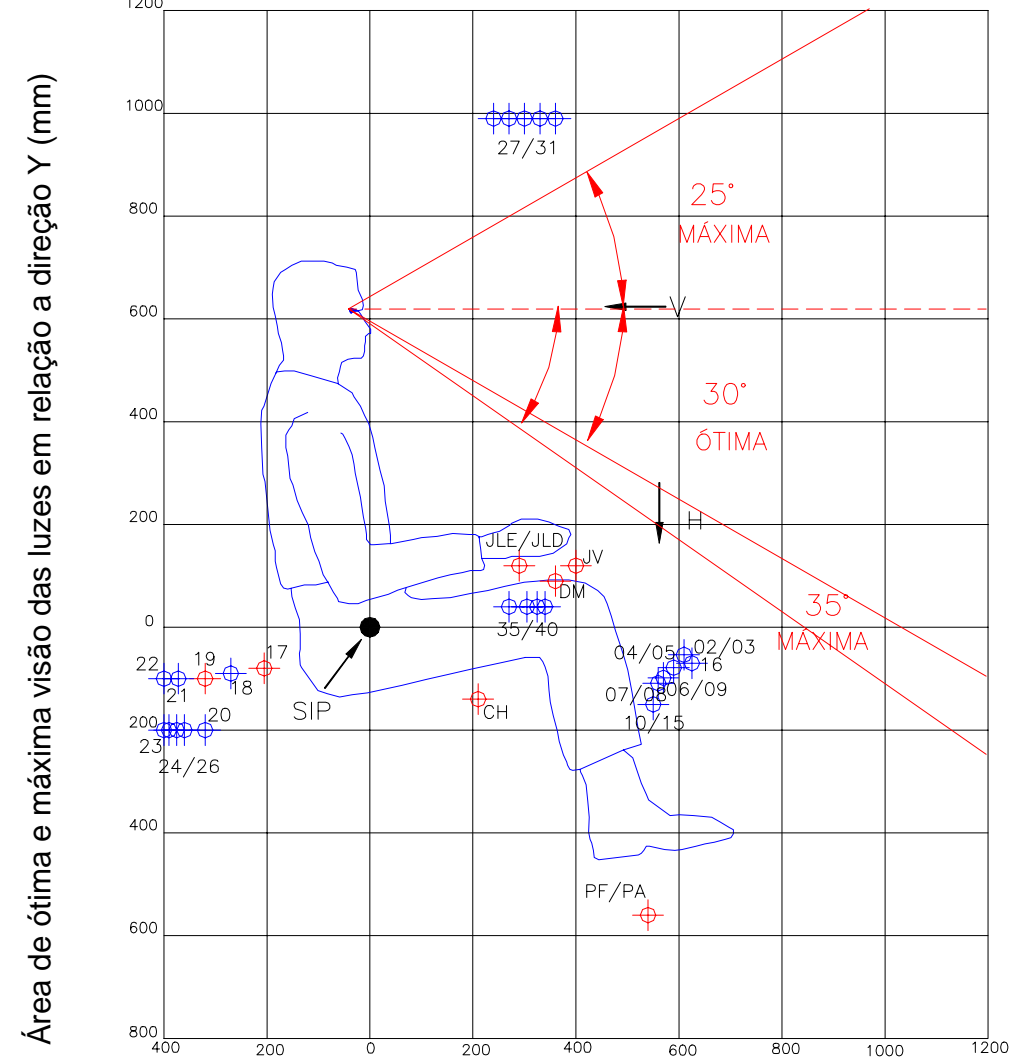

Área de ótima e máxima visão das luzes em relação a direção X (mm)

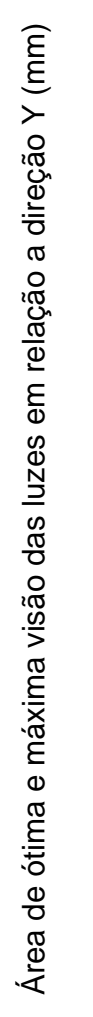

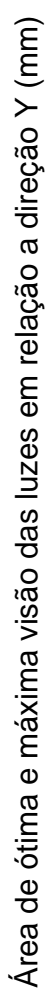

Figura 22 - Área de visão ótima e máxima de comandos do "forwarder" Timberjack 1210B.
Área de ótima e máxima visão das luzes em relação a direção X (mm)

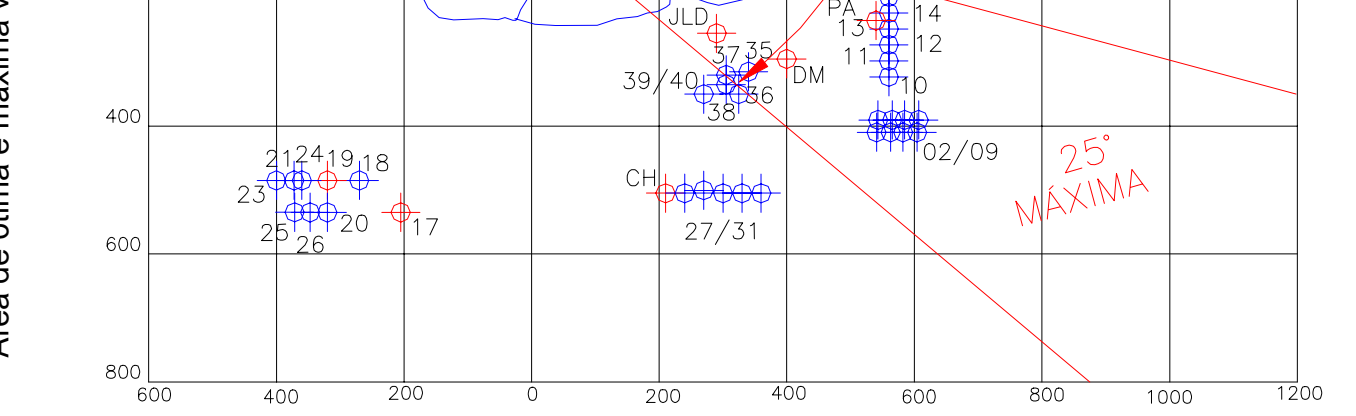

CH - Interruptor de Ignição (Chave)

2 - Luz avisadora de Sinal de deslocamento 3 - Luz dos Faróis de trabalh

5 - Luz do Sistema El

6- Luz de Pressão de Ótrico (Alternador)

7 - Luz do Freio de Estacionamento

8 - Luz de Pressão de Abastecimento Óleo

9 - Luz do Nível de Combustive

10 - Interruptor dos Faróis

Controle médio/máximo

3 - Interru

de Piscas Intermitentes

14 - Inter. Lavadores dos Vidros

17 - Intermeg de Acesso a Cabine

18 - Internut do Conda de Tenécia

19 - Inter. Trava do Freio de Estacionamento

20 - Interruptor do Condicionador de $\mathrm{Ar}$

21 - Interruptor do bloqueio $6 \times 6$

22 - Interruptor de RPM

23 - Interruptor de Trava Chassis

24 - Intertuptores do Movimento Malhal

25 - Inter. Limpador de Pára-brisa Traseiro E

Intermitente

27 - Interruptor de Faróis de Trabalho

28 - Interruptor de Faróis de Trabalho

29 - Interruptor de Faróis de Trabalho

31 - Interruptor de Faróis de Trabaho

JV - "Joystick" do Volante da Máquina

JLE - "Joystick" do Comando da Grua

JLD - "Joystick" do Comando da Grua

35 - Interruptor de Sentido de Deslocamento

36 - Internuptor do Limpador de Pára-brisa 


\subsection{2 "Forwarder" Timberjack modelo 1710D}

$\mathrm{Na}$ Figura 23 observa-se a distribuição espacial dos cinqüenta e um comandos nas três posições do assento e verifica-se que apenas dois (4,0\%) destes comandos receberam o conceito de "ótimo" ("joysticks" do comando da grua do lado esquerdo e direito), um só comando foi sempre classificado como "bom" (Interruptor de direção da máquina) e dois comandos foram classificados como "regulares" (os pedais do acelerador e do freio), sendo que esses poderiam vir a ocasionar um desconforto para o operador durante a operação (Tabela 9). Comparando a distribuição espacial dos comandos conforme o posicionamento do assento, observa-se que, com o posicionamento do assento em "próximo", 56,9\% dos mesmos conseguiram conceitos entre "bom" e "ótimo", em posição "médio" foram 43,0\% e, em "extremo", 49,0\% do total dos comandos.

Tabela 9. Distribuição espacial dos cinqüenta e um comandos do "forwarder" Timberjack 1710D na avaliação espacial das coordenadas x-y e x-z

\begin{tabular}{lccc}
\hline \multirow{2}{*}{ Conceito } & \multicolumn{3}{c}{ Posicionamento do assento } \\
\cline { 2 - 4 } & Próximo & Médio & Extremo \\
\hline Ótimo & $2(4,0 \%)$ & $2(4,0 \%)$ & $2(4,0 \%)$ \\
Muito Bom & $13(25,5 \%)$ & $11(21,5 \%)$ & $11(21,5 \%)$ \\
Bom & $14(27,4 \%)$ & $9(17,5 \%)$ & $12(23,5 \%)$ \\
Regular & $8(15,7 \%)$ & $5(10,0 \%)$ & $4(8,0 \%)$ \\
Ruim & $14(27,4 \%)$ & $24(47,0 \%)$ & $22(43,0 \%)$ \\
\multicolumn{1}{c}{ Total } & $51(100,0 \%)$ & $51(100,0 \%)$ & $51(100,0 \%)$ \\
\hline
\end{tabular}

Considerando a distribuição espacial das luzes de advertência referentes ao campo visual, foram encontrados oito $(89,0 \%)$ luzes de advertência e o monitor (11,0\%) ("display") classificados como "regular". Pode-se observar que todas as luzes de sinalização ou até mesmo de advertência estão posicionadas à frente e ao lado direito do operador (Figura 24). 


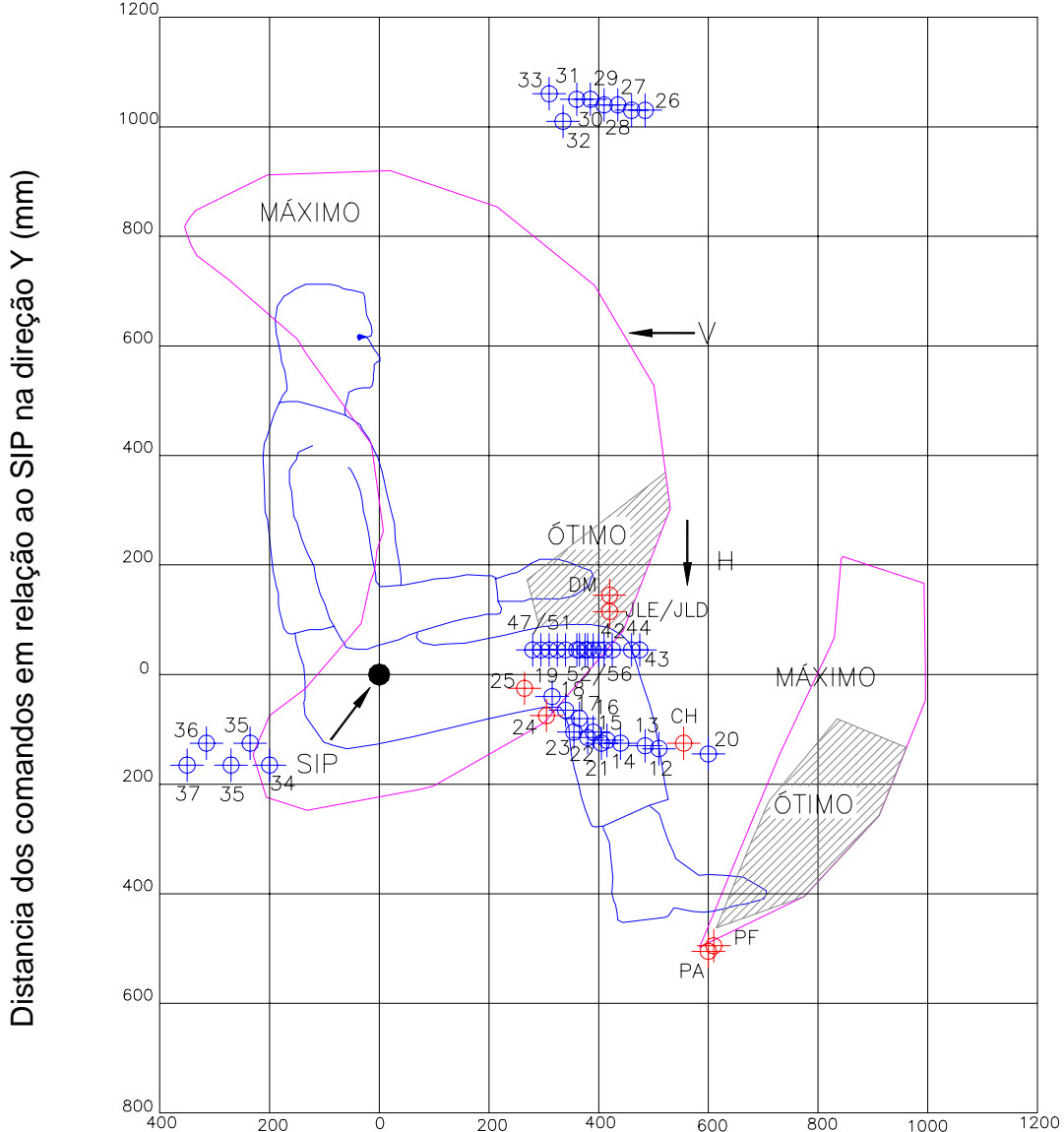

Distancia dos comandos em relação ao SIP na direção X (mm)

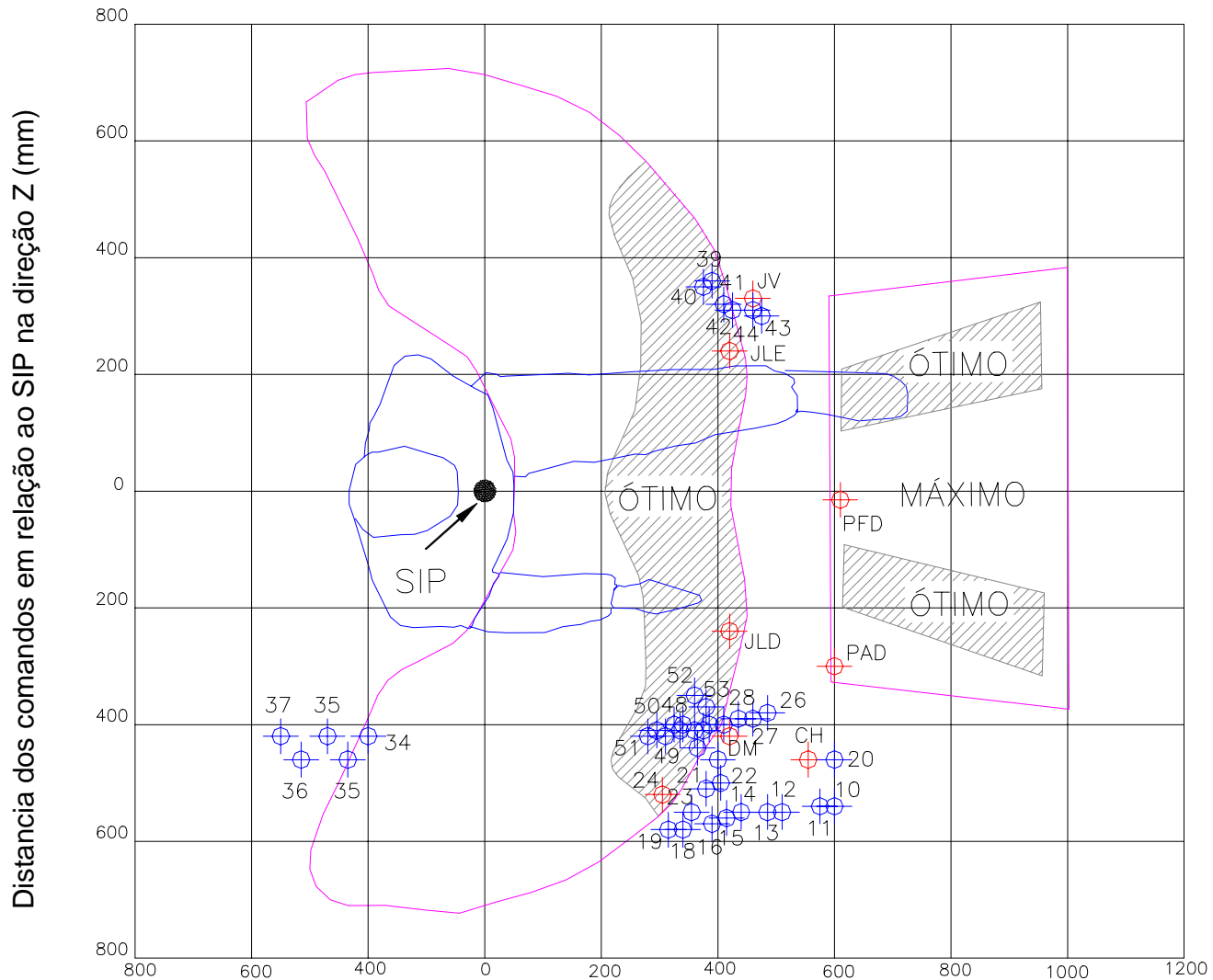

Distancia dos comandos em relação ao SIP na direção X $(\mathrm{mm})$

Figura 23 - Localização dos órgãos de comandos do "forwarder" Timberjack 1210D, nas três dimensões.

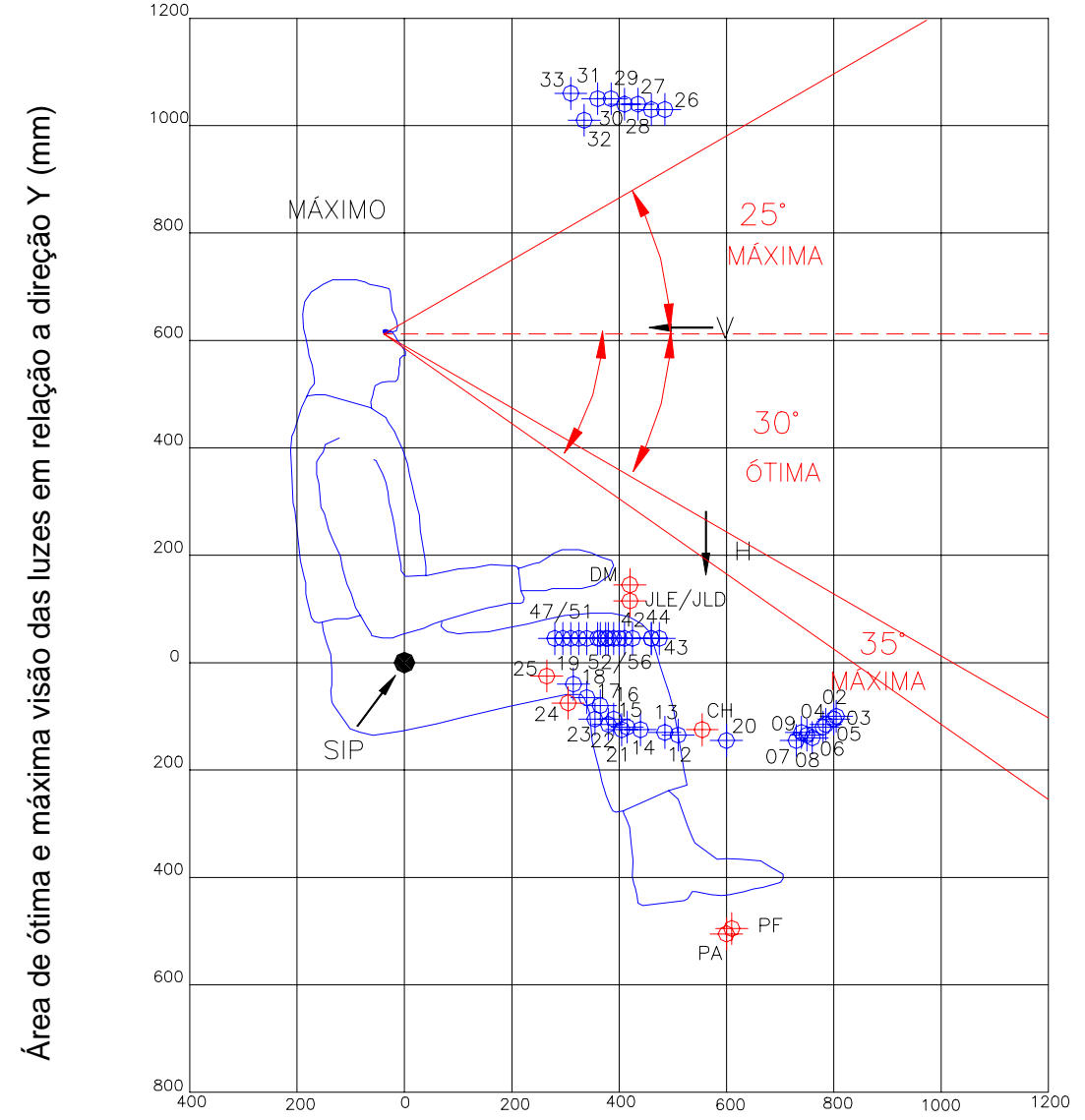

Área de ótima e máxima visão das luzes em relação a direção X (mm)

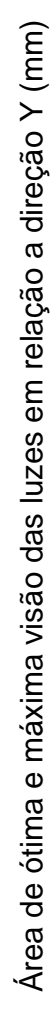

Área de ótima e máxima visão das luzes em relação a direcão X (mm)

Figura 24 - Área de visão ótima e máxima de comandos do "forwarder" Timberjack 1710D.
$\mathrm{CH}$ - Interruptor de Ignição (Chave)

2 - Luz avisadora de Sinal de deslocamento

3 - Luz dos Faróis de trabalho

4- Luz de Farol Alto

5 - Luz do Sistema Elétrico (Alternado

7- Luz do Preio de do Oleo de motor

8 - Luz de Pressão do Acumulador

9 - Luz de Pressão Oleo Transmissão

10 - Interruptor do Pisca

11 - Buzina
12 - Inter. Degrau de Acesso a Cabine

13 - Interruptor do bloqueio $6 \times 6$

15 - Inter. Limpador de Pára-brisa

16 - Inter. Limpador de Pára-brisa

17 - Inter. Limpador de Pára-brisa

18 - Inter. Limpador de Pára-brisa

19 - Inter. Limpadr de Para-brisa

21 - Interruptor de Luz Alta

22 - Interruptor dos Faróis

23 - Interruptor da Direção Máquina

24 - Inter. Freio de Estacionamento

25 - Inter. Parada de Emergência

26 - Interruptor de Faróis de Serviço

28 - Interruptor de Faróis de Servico

29 - Interruptor de Faróis de Serviço

30 - Interruptor de Faróis de Serviço

31 - Interruptor de Faróis de Serviço

32 - Interruptor de Faróis de Serviço

33 - Inter. do Ventiador de Teto

35 - Inter. Controle Velocidade Temp.

35- Inter. Controle Temp. (quente/frio)

36 - Interruptor de Saídas

37 - Inter. Desembaçador Interno Cabine

DM - Monitor ("Display")

(Volante)

40 - Botão de Baixar Malhal

41 - Botão Desacoplar Freio Torcional

42 - Botão de Rotação de Trabalho

43 - Botão Bloqueio acionar Dif.(6x6)

44 -Botão Bloqueio Desacionar Dif. $(6 \times 6)$

JLD - "Joystick" do Comando da Grua

47 - Botão de Acesso Display (A)

48 - Botão de Acesso Display (B)

49 - Botão de Acesso Display (C)

50 - Botão de Acesso Display (D)

51 - Botão de Acesso Display (E)

53 - Botão de Velocidades Altas/Baixto

54 - Botão da Grua ligada/desligada

55 - Botão de Aquecimento Acento

56 - Botão Limp. Pára-brisa de Carga

PF - Pedal de Freio 


\subsection{3 "Forwarder" Valmet modelo 890.2}

Analisando-se o "forwarder" 890.2 em relação ao posicionamento espacial dos comandos nas três posições do assento, observa-se que dos quarenta e oito comandos, apenas dois (4,0\%) foram classificados como "ótimo" (Tabela 10). Independentemente ao posicionamento do assento, observou-se que os pedais de freio e o acelerador foram classificados respectivamente como muito bom" e "regular" (Figura 25).

Quanto ao posicionamento do assento em estudo, observa-se que, existe uma diferença na distribuição dos comandos, onde 62,5\% encontram-se com o posicionamento em "próximo", 66,7\% em "médio" e 52,0\% em "extremo", quando considera-se a somatória dos conceitos "ótimo, "muito bom" e "bom". No caso deste modelo, observa-se que a melhor classificação foi obtida com o posicionamento em "médio", o que permite a sua melhor adequação para um número maior de operadores, haja vista que a análise feita neste trabalho, baseou-se no biótipo do operador médio.

Em relação aos comandos que foram classificados como "regular" e "ruim", observa-se que, na maioria das vezes, são utilizados principalmente quando a jornada de trabalho é noturna, como, por exemplo, os interruptores de farol.

Tabela 10. Distribuição espacial dos quarenta e oito comandos do "forwarder" Valmet 890.2 na avaliação espacial das coordenadas $x-y$ e x-z

\begin{tabular}{lccc}
\hline \multirow{2}{*}{ Conceito } & \multicolumn{3}{c}{ Posicionamento do assento } \\
\cline { 2 - 4 } & Próximo & Médio & Extremo \\
\hline Ótimo & $2(4,0 \%)$ & $2(4,0 \%)$ & $2(4,0 \%)$ \\
Muito Bom & $19(39,5 \%)$ & $21(43,7 \%)$ & $19(39,5 \%)$ \\
Bom & $9(19,0 \%)$ & $9(19,0 \%)$ & $4(8,5 \%)$ \\
Regular & $7(14,5 \%)$ & $12(25,0 \%)$ & $15(31,5 \%)$ \\
Ruim & $11(23,0 \%)$ & $4(8,3 \%)$ & $8(16,0 \%)$ \\
\multicolumn{1}{c}{ Total } & $48(100,0 \%)$ & $48(100,0 \%)$ & $48(100,0 \%)$ \\
\hline
\end{tabular}


Analisando a distribuição espacial das luzes de advertência (Tabela 11), observou-se um campo visual diferenciado em função do posicionamento do assento. Para a posição "próximo" todas as cinco luzes de advertência obtiveram o conceito "bom"; com o assento em posicionamento "médio" quatro (80,0\%) luzes de advertência classificaram-se como "muito bom" e uma (20,0\%) como "bom". Já para o posicionamento do assento em "extremo" todas as luzes de advertência obtiveram o conceito "ótimo" (Figura 26). Essa boa classificação em todas as posições demonstra a boa qualidade de projeto em função da correta adaptação dos instrumentos independentemente da posição do assento.

Tabela 11. Distribuição espacial das cinco luzes de advertência do "forwarder" Valmet 890.2 do ponto de vista do campo visual

\begin{tabular}{lccc}
\hline \multirow{2}{*}{ Conceito } & \multicolumn{3}{c}{ Posicionamento do assento } \\
\cline { 2 - 4 } & Próximo & Médio & Extremo \\
\hline Ótimo & ------- & ------- & $5(100,0 \%)$ \\
Muito Bom & ------ & $4(80,0 \%)$ & ------- \\
Bom & $5(100,0 \%)$ & $1(20,0 \%)$ & ------- \\
Regular & ---------- \\
Ruim & ------- & ------ & ----- \\
\multicolumn{1}{r}{ Total } & $5(100,0 \%)$ & $5(100,0 \%)$ & $5(100,0 \%)$ \\
\hline
\end{tabular}




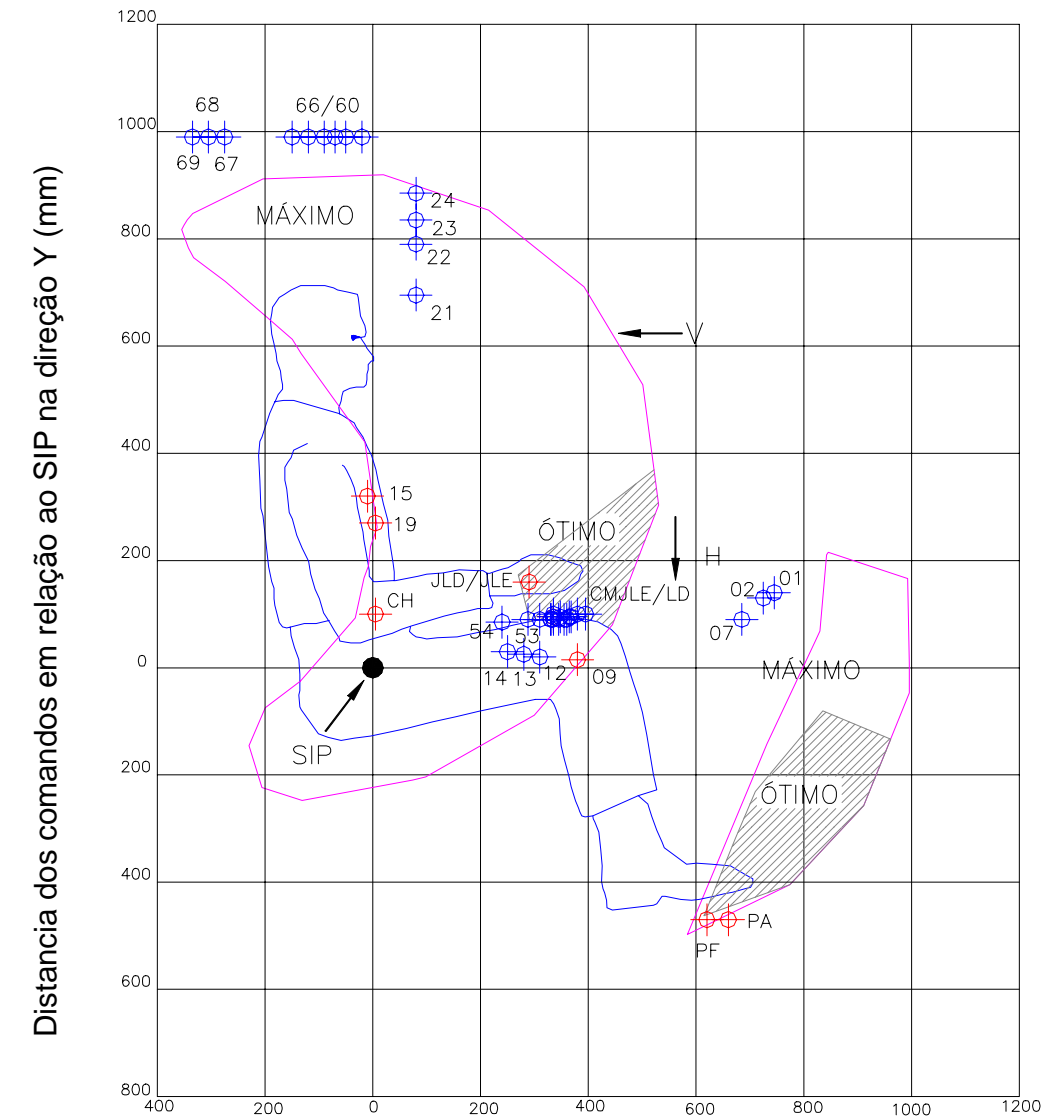

Distancia dos comandos em relação ao SIP na direção X (mm)

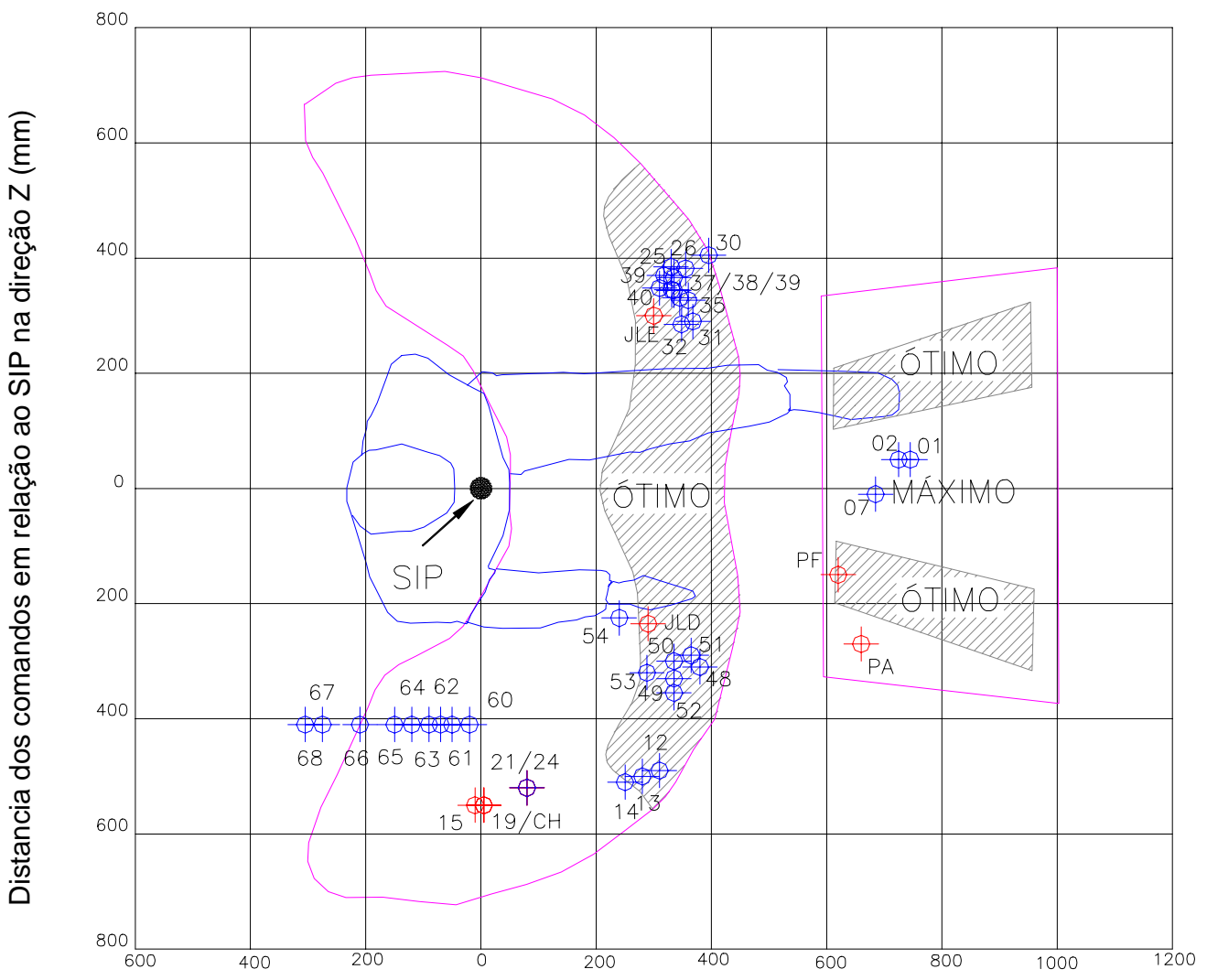

Distancia dos comandos em relação ao SIP na direção $\mathrm{X}(\mathrm{mm})$

Figura 25 - Localização dos órgãos de comandos do "forwarder" Valmet 890.2, nas três dimensões.

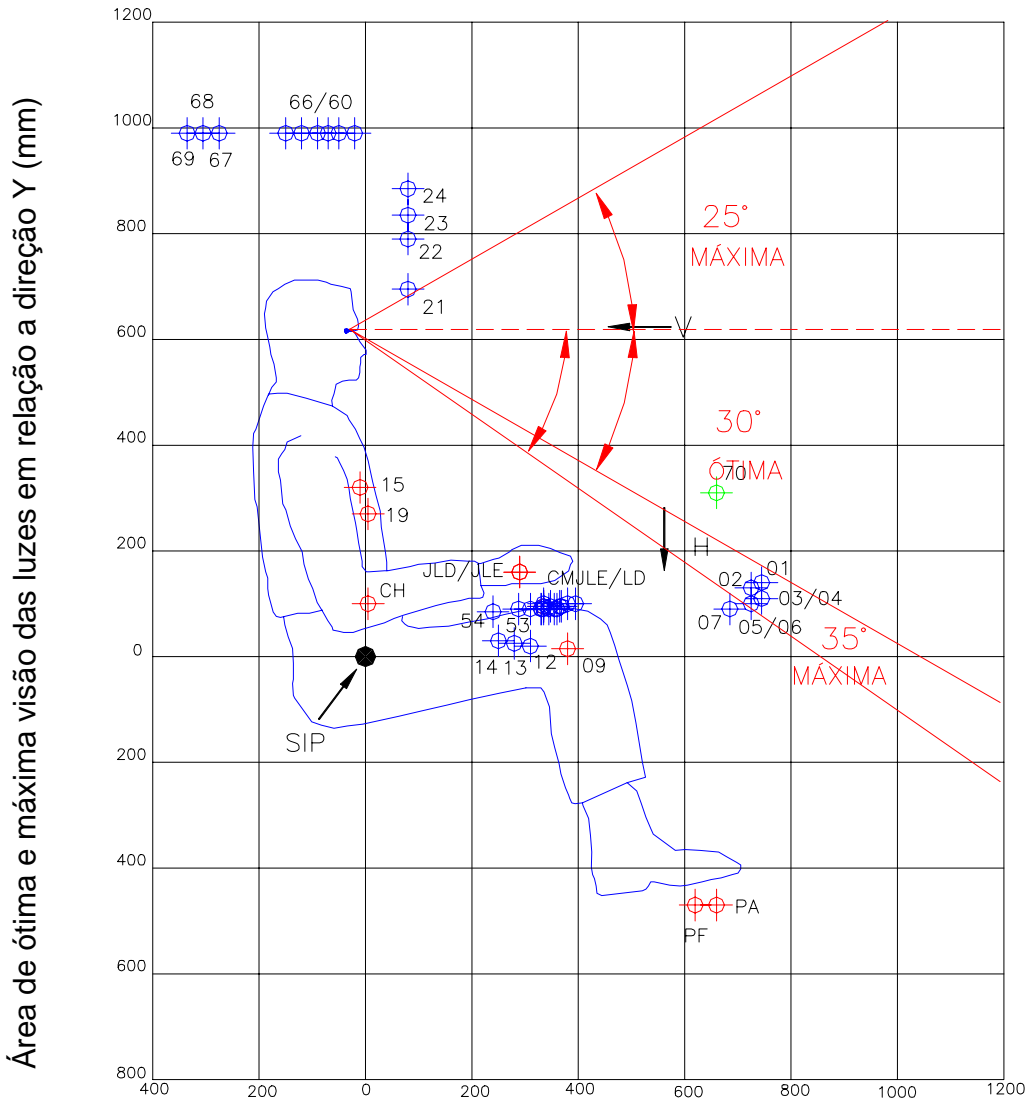

Área de ótima e máxima visão das luzes em relação a direção X (mm)

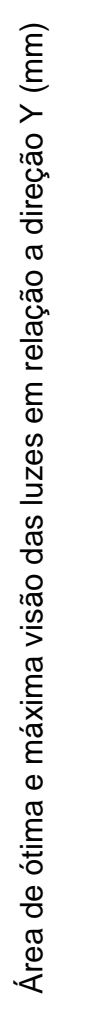

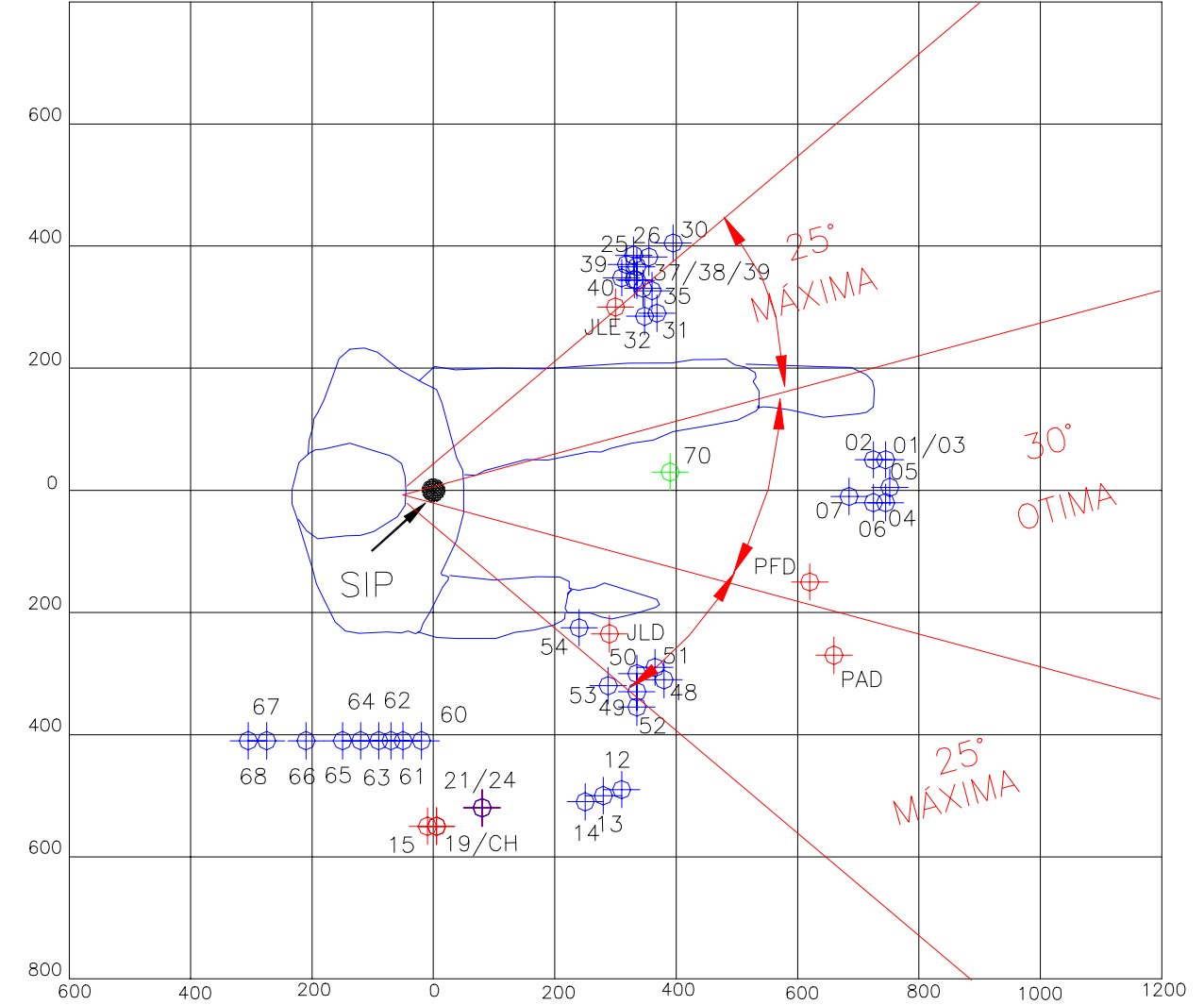

Área de ótima e máxima visão das luzes em relação a direção X (mm)

Figura 26 - Área de visão ótima e máxima de comandos do "forwarder" Valmet 890.2 .

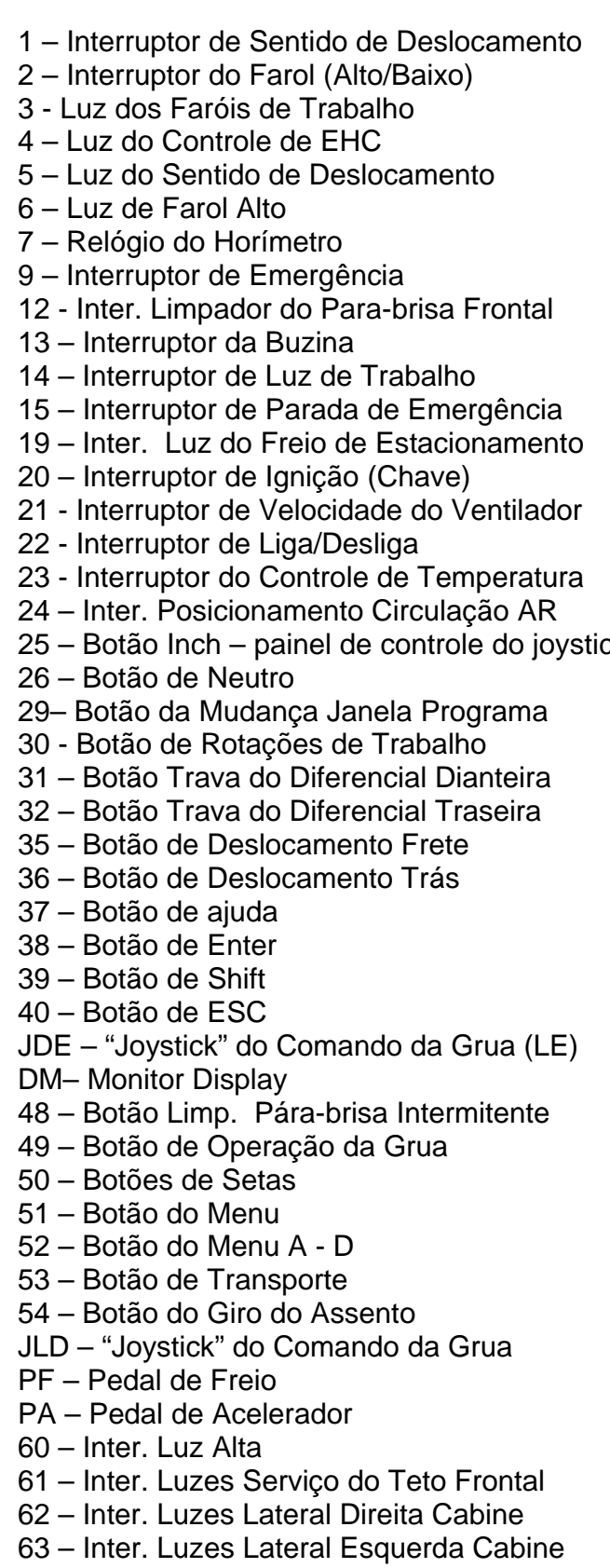

1 - Interruptor de Sentido de Deslocamento 1

$5-$ Luz do Sentido de
6 - Luz de Farol Alto

12 - Inter. Limpador do Para-brisa Frontal

13 - Interruptor da Buzina

$u z$ do Freio de Estacionamento

21 - Interruptor de Velocidade do Ventilado

22 - Interruptor de Liga/Desliga

inel de controle do joystick

30 - Botão de Rotaç̃ões de Trabalho

- Botão Trava do Diferencial Dianteira

35 - Botão de Deslocamento Frete

37 - Botão de ajuc

39 - Botão de Shift

Y)

- Botão do Menu A -

53 - Botão de Transporte

JLD - "Joystick" do Comando da Grua

PA - Pedal de Acele

61 - Inter. Luzes Serviço do Teto Frontal

63 - Inter. Luzes Lateral Esquerda Cabine 


\subsection{4 "Forwarder" Volvo modelo A25C}

Em relação à distribuição espacial dos trinta e um (100,0\%) comandos nas três posições do assento (Tabela 12), observa-se que apenas 6,5\% dos comandos receberam conceito "ótimo", e 13,0\% como "muito bom" (Figura 27). Dos comandos que receberam o conceito "ótimo", destacam-se o volante e o pedal de freio, e para os comandos como "muito bom" são os "joysticks" do comando da grua do lado esquerdo e direito e pedal do acelerador, para as três posições do assento.

Quando comparadas a distribuição dos comandos nos diferentes posicionamentos do assento, verifica-se que este "forwarder" apresentou a menor porcentagem dos comandos em posição adequada, quando comparados com os demais.

Tabela 12. Distribuição espacial dos trinta e um comandos do "forwarder" Volvo A25C na avaliação espacial das coordenadas $x-y$ e $x-z$

\begin{tabular}{lccc}
\hline \multirow{2}{*}{ Conceito } & \multicolumn{3}{c}{ Posicionamento do assento } \\
\cline { 2 - 4 } & Próximo & Médio & Extremo \\
\hline Ótimo & $2(6,5 \%)$ & $2(6,5 \%)$ & $2(6,5 \%)$ \\
Muito Bom & $4(13,0 \%)$ & $4(13,0 \%)$ & $4(13,0 \%)$ \\
Bom & $5(16,0 \%)$ & $7(22,5 \%)$ & $6(19,0 \%)$ \\
Regular & $11(35,5 \%)$ & $7(22,5 \%)$ & $2(6,5 \%)$ \\
Ruim & $9(29,0 \%)$ & $11(35,5 \%)$ & $17(55,0 \%)$ \\
\multicolumn{1}{c}{ Total } & $31(100,0 \%)$ & $31(100,0 \%)$ & $31(100,0 \%)$ \\
\hline
\end{tabular}

Analisando a distribuição espacial das luzes de advertência em relação ao campo visual, na Tabela 13 podemos observar que, dependendo do posicionamento do assento, constata-se uma distribuição diferenciada, onde para o assento na posição "próximo" 70,0\% dos instrumentos mostradores, luzes de advertência e indicadores obtiveram o conceito "bom", com o posicionamento do assento em "médio" 60,0\% classificaram-se como "muito 
bom" e 20,0\% como "bom". Já para o posicionamento do assento em "extremo", 90,0\% encontravam-se entre "bom" e "ótimo" (Figura 28).

Tabela 13. Distribuição espacial das trinta luzes de advertência do "forwarder" Volvo A25C do ponto de vista do campo visual

\begin{tabular}{lccc}
\hline \multirow{2}{*}{ Conceito } & \multicolumn{3}{c}{ Posicionamento do assento } \\
\cline { 2 - 4 } & Próximo & Médio & Extremo \\
\hline Ótimo & ------- & ------ & $16(53,5 \%)$ \\
Muito Bom & ------ & $18(60,0 \%)$ & $5(16,5 \%)$ \\
Bom & $21(70,0 \%)$ & $6(20,0 \%)$ & $6(20,0 \%)$ \\
Regular & $6(20,0 \%)$ & $3(10,0 \%)$ & $2(6,5 \%)$ \\
Ruim & $3(10,0 \%)$ & $3(10,0 \%)$ & $1(3,5 \%)$ \\
\multicolumn{1}{c}{ Total } & $30(100,0 \%)$ & $30(100,0 \%)$ & $30(100,0 \%)$ \\
\hline
\end{tabular}




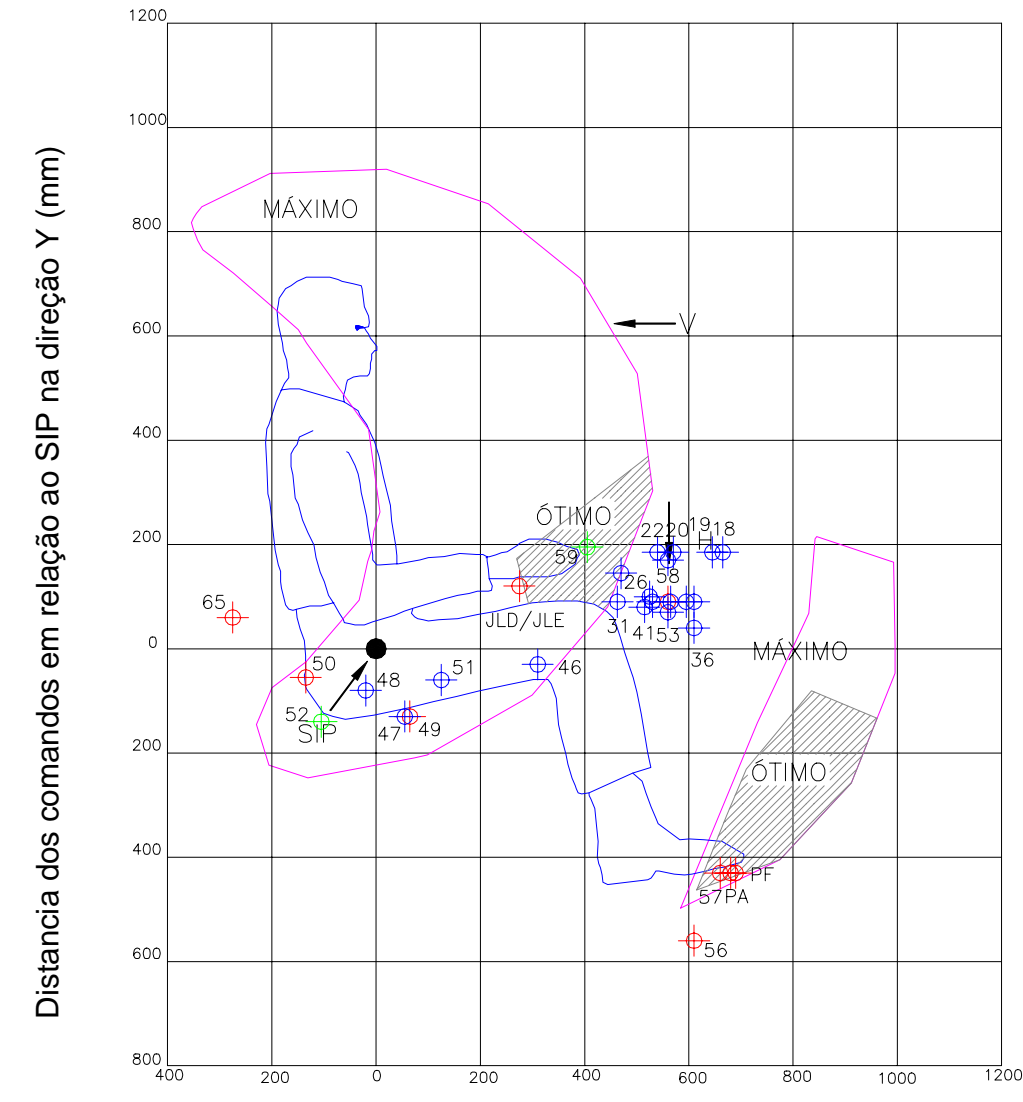

Distancia dos comandos em relação ao SIP na direção X (mm)

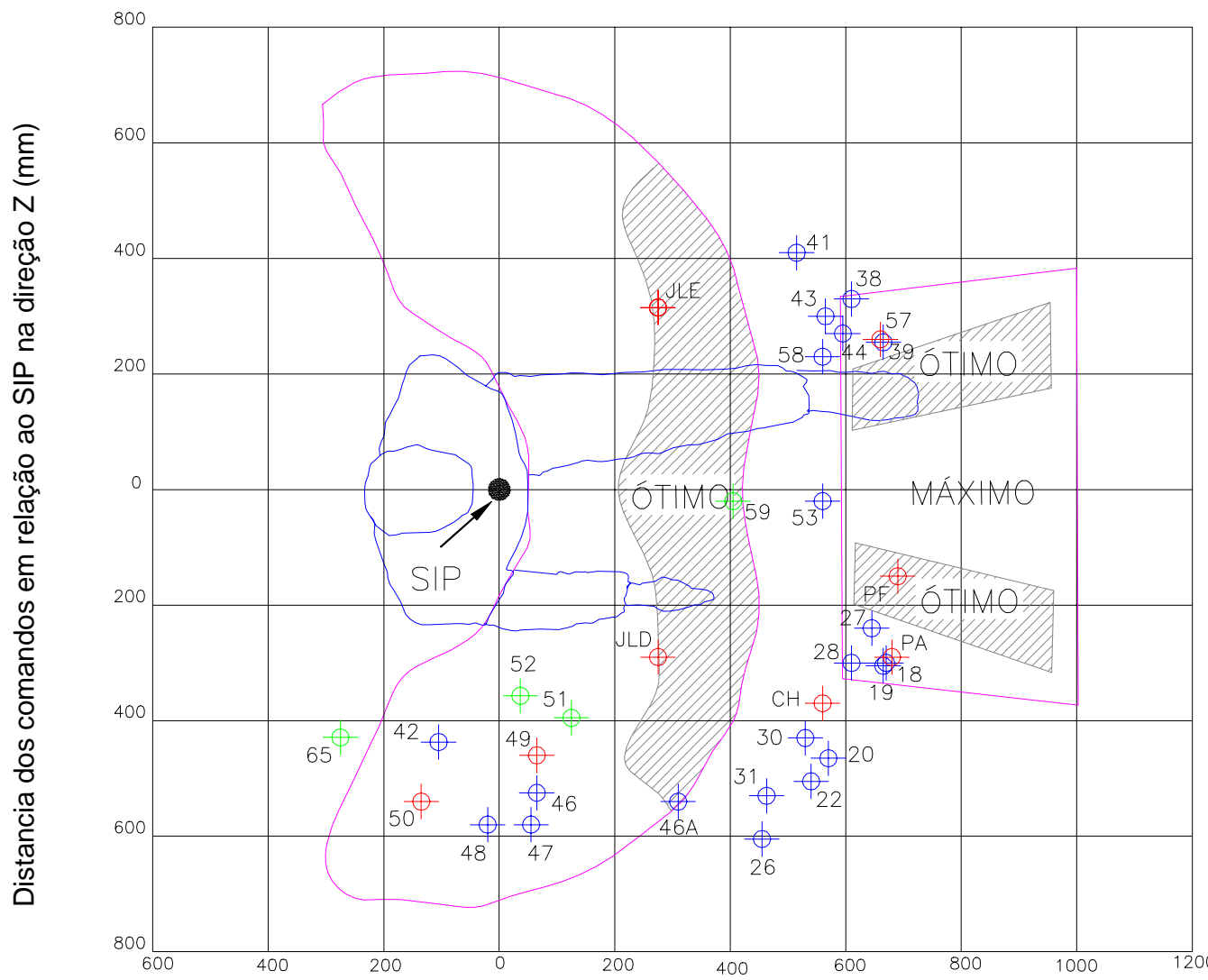

Distancia dos comandos em relação ao SIP na direção $X(\mathrm{~mm})$

Figura 27 - Localização dos órgãos de comandos do "forwarder" Volvo A25C, nas três dimensões.

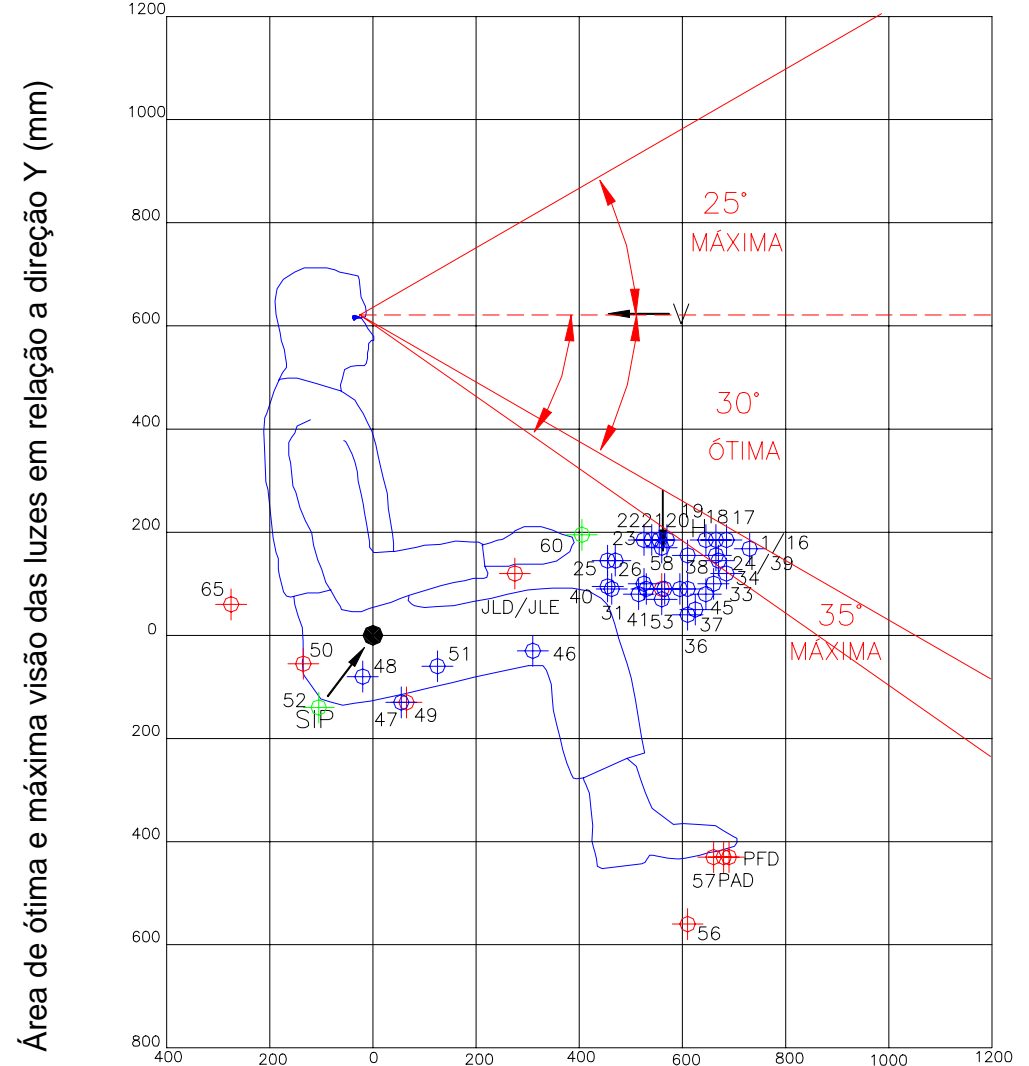

Área de ótima e máxima visão das luzes em relação a direção X (mm)

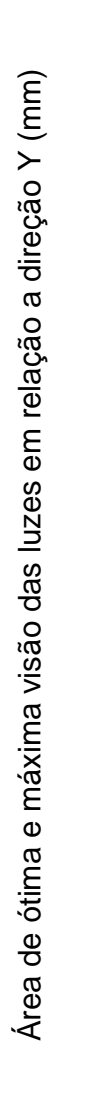

Área de ótima e máxima visão das luzes em relação a direção X (mm)

Figura 28 - Área de visão ótima e máxima de comandos do "forwarder" Volvo A25C.

\author{
1 - Interruptor de Sentido de Deslocamento \\ 2 - Interruptor do Farol (Alto/Baixo) \\ 4 - Luz do Controle de EHC \\ 5 - Luz do Sentido de Deslocamento \\ 6 - Luz de Farol Alto \\ 9 - Interruptor de Emergência \\ 12 - Inter. Limpador do Para-brisa Frontal \\ 13 - Interruptor da Buzina \\ 14 - Interruptor de Luz de Trabalho \\ 15 - Interruptor de Parada de Emergência \\ 19 - Inter. Luz do Freio de Estacionamento \\ 21 - Interruptor de Velocidade do Ventilador \\ 22 - Interruptor de Liga/Desliga \\ 23 - Interruptor do Controle de Temperatura \\ 24 - Inter. Posicionamento Circulação AR \\ 25 - Botaro \\ 29- Botão da Mudan \\ 30 - Botão de Rotaç̃ós Janela Program \\ 31 - Botão Trava doçes de Trabalho \\ 32 - Botõo Trava do Diferencial Dianteira \\ 35 - Botão de Deso Direrencial Traseira \\ 36 - Botão de Deslocamento Trás \\ 37 - Botão de ajuda \\ 38 - Botão de Enter \\ 40 - Botão de ESC \\ JDE - "Joystick" do Comando da Grua (LE) \\ DM- Monitor Display \\ 48 - Botão Limp. Pára-brisa Intermitente \\ 49 - Botão de Operação da Grua \\ 50 - Botões de Setas \\ 52 - Botão do Menu A - \\ 53 - Botão de Transporte \\ 54 - Botão do Giro do Assento \\ JLD - "Joystick" do Comando da Grua \\ PA - Pedal de Acelerador \\ $61-$ Inter. Luzes Serviço do Teto Frontal
61 . Luz Alta \\ 62 - Inter. Luzes Lateral Direita Cabine
}




\subsection{5 "Skidder" Caterpillar modelo 545}

$\mathrm{Na}$ Tabela 14 observa-se que apenas um dos vinte e quatro $(100,0 \%)$ comandos recebeu o conceito "ótimo" ("joystick" do comando da grua) nos três posicionamentos do assento (Figura 29). Observando-se a distribuição dos comandos, constatou-se que $70,0 \%$ dos comandos receberam o conceito de "ótimo", "muito bom" e "bom" para o assento posicionado em "extremo", 54,5\% em "médio" e 46,0\% em "próximo". Dois comandos utilizados durante a jornada de trabalho encontravam-se localizados em uma região com o conceito "ruim": os pedais de freio e acelerador.

Tabela 14. Distribuição espacial dos vinte e quatro comandos do "skidder" Caterpillar 545 na avaliação espacial das coordenadas x-y e x-z

\begin{tabular}{lccc}
\hline \multirow{2}{*}{ Conceito } & \multicolumn{3}{c}{ Posicionamento do assento } \\
\cline { 2 - 4 } & Próximo & Médio & Extremo \\
\hline Ótimo & $1(4,0 \%)$ & $3(12,5 \%)$ & $1(4,0 \%)$ \\
Muito Bom & $5(21,0 \%)$ & $5(21,0 \%)$ & $1(4,0 \%)$ \\
Bom & $5(21,0 \%)$ & $5(21,0 \%)$ & $16(67,0 \%)$ \\
Regular & $3(12,5 \%)$ & $3(12,5 \%)$ & $2(8,5 \%)$ \\
Ruim & $10(41,5 \%)$ & $8(33,0 \%)$ & $4(16,5 \%)$ \\
\multicolumn{1}{c}{ Total } & $24(100,0 \%)$ & $24(100,0 \%)$ & $24(100,0 \%)$ \\
\hline
\end{tabular}

Apesar da quantidade de comandos que receberam o conceito classificado como "regular" e "ruim", há que se considerar que boas partes desses comandos são acionadas com menor freqüência, com exceção dos pedais de freio e acelerador.

Considerando-se a distribuição espacial dos instrumentos mostradores e luzes de advertência, com o posicionamento do assento nas três posições em estudo (Tabela 15), observa-se que as oito luzes de advertência e os quatro instrumentos mostradores apresentaram uma boa distribuição com a localização do assento em "próximo" e "extremo". Pôde-se observar que todas 
as luzes de advertências e instrumentos mostradores estavam posicionados à frente do operador (Figura 30).

Tabela 15. Distribuição espacial das doze luzes de advertência do "skidder" Caterpillar 545 do ponto de vista do campo visual

\begin{tabular}{lccc}
\hline \multirow{2}{*}{ Conceito } & \multicolumn{3}{c}{ Posicionamento do assento } \\
\cline { 2 - 4 } & Próximo & Médio & Extremo \\
\hline Ótimo & ------- & ------ & $8(66,5 \%)$ \\
Muito Bom & $12(100,0 \%)$ & ------ & $4(33,5 \%)$ \\
Bom & ------- & $9(75,0 \%)$ & ------ \\
Regular & ------- & $3(25,0 \%)$ & ------ \\
Ruim & ------ & ------ & $12(100,0 \%)$ \\
\multicolumn{1}{r}{ Total } & $12(100,0 \%)$ & $12(100,0 \%)$ & \\
\hline
\end{tabular}




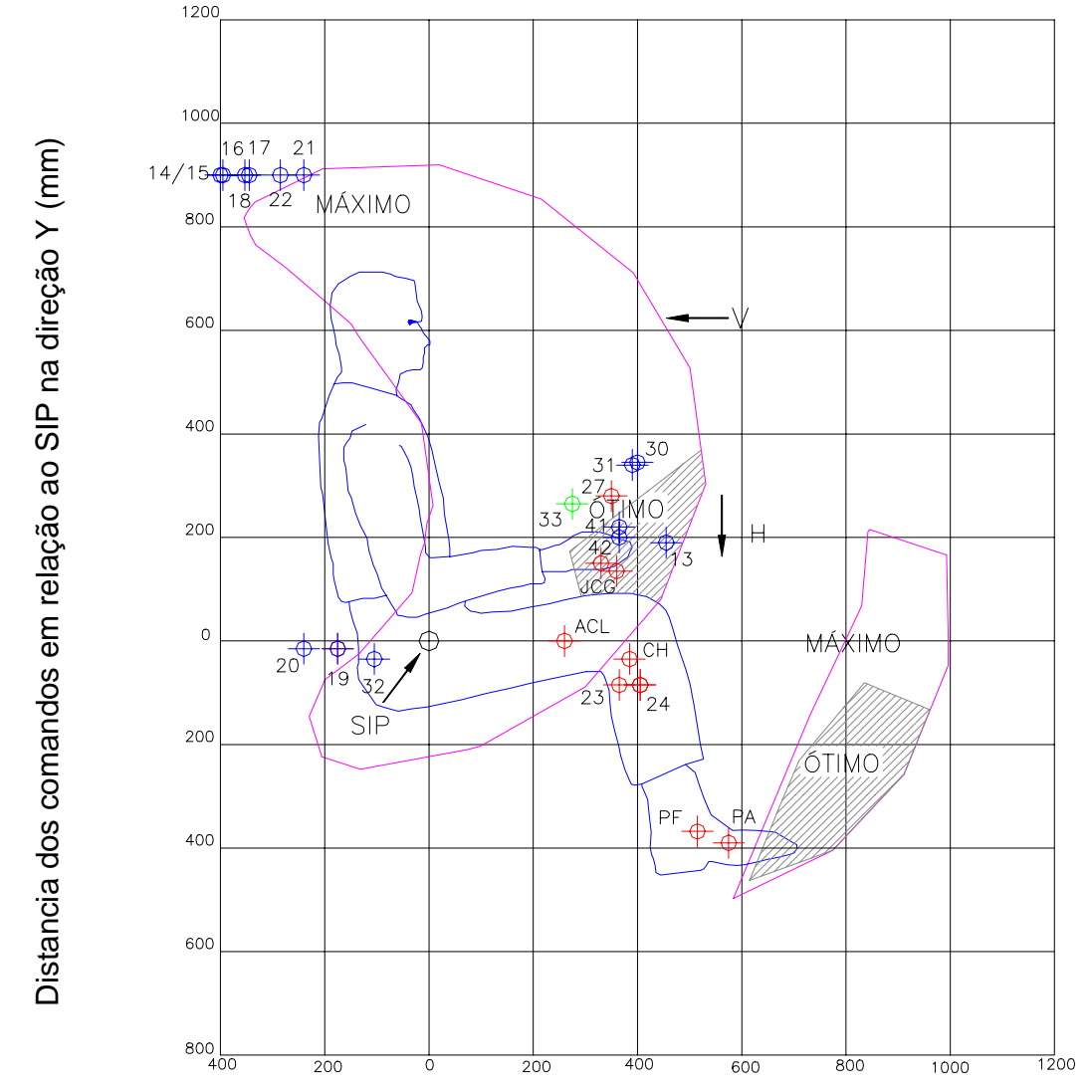

Distancia dos comandos em relação ao SIP na direção X (mm)

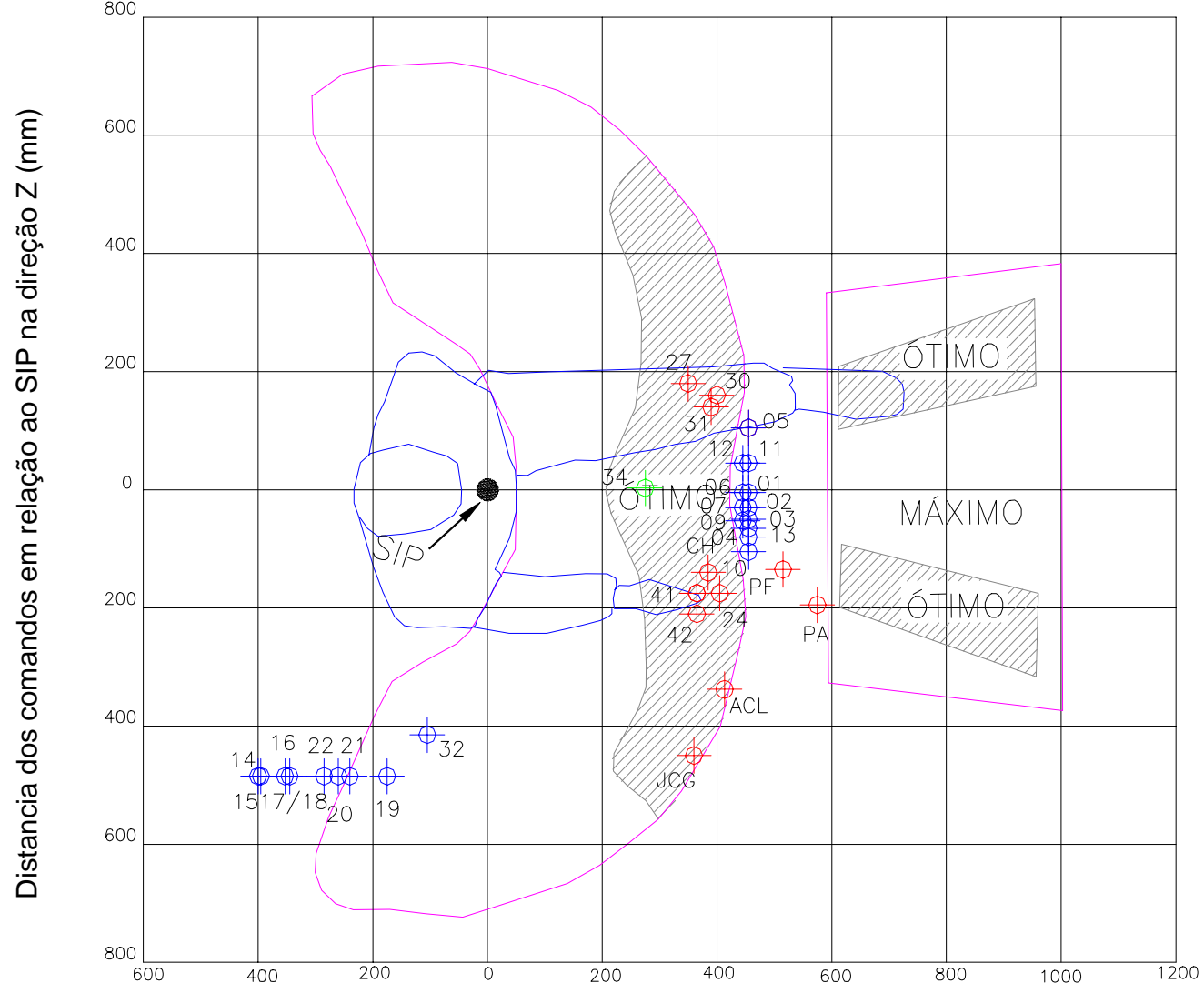

Distancia dos comandos em relação ao SIP na direção $X(\mathrm{~mm})$

Figura 29 - Localização dos órgãos de comandos do "skidder" Caterpillar 545, nas três dimensões.

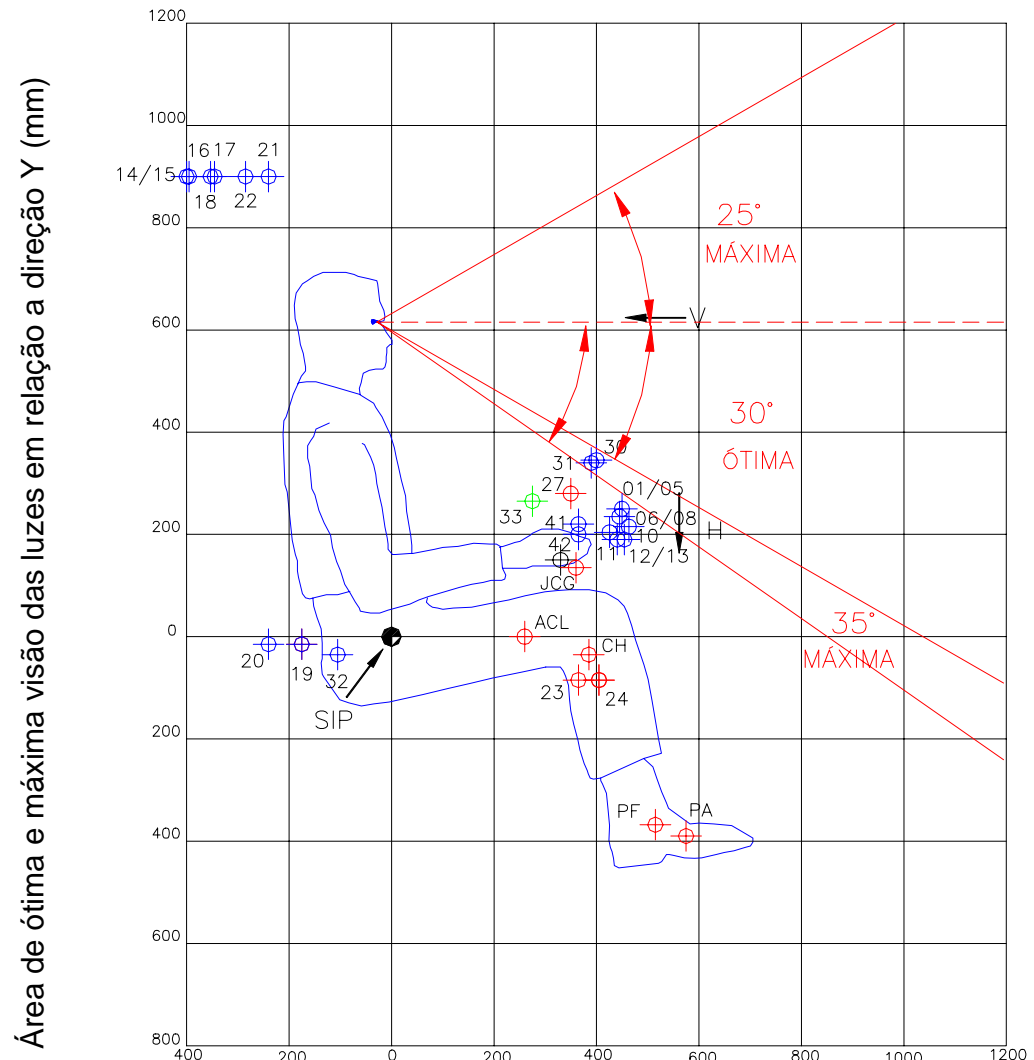

Área de ótima e máxima visão das luzes em relação a direção X (mm)

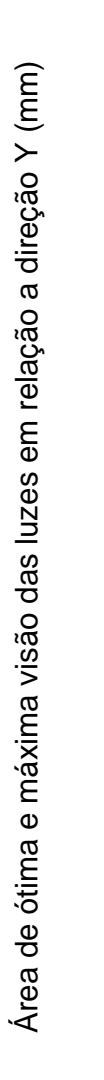

Área de ótima e máxima visão das luzes em relação a direção X (mm)

Figura 30 - Área de visão ótima e máxima de comandos do "skidder" Caterpillar 545.
1- Luz de Pressão do Óleo de motor

- Luz do Freio de Estacionamento

3 - Luz da Pressão Oleo de Freio

4 - Luz do Sistema Elétrico

5 - Luz do Nivel de Combustivel
6 - Luz dos Braços Automático da Garra

7 - Luz do Filtro do Óleo de Transmissão

8 - Luz da Trava do Diferencial
9 - Relógio Temperatura Motor

9 - Relógio Temperatura Motor

10 - Relógio Temperatura Oleo da Transmissán

11 - Relógio Temperatura Oleo Hidráulico
12 - Relógio Nível de Combustivel

13 - Interruptor do Visor

Digital/Horímetro/RPM/March

14 - Interruptores dos Faróis Dianteiros

15 - Interruptores dos Faróis Traseiros

16 - Interruptores do Lavadores dos Vidros

18 - Inter. Limpador de Pará-brisa Traseiro

19 - Inter. Aquecedor e Condicionador de A

20 - Interruptor do Controle de Temperatura

21 - Interruptor do Ventilador Traseiro

22 - Interruptor do Ventilador Dianteiro

23 - Alavanca do Freio de Estacionamento

(Acionada)

- Cambio (Avante)

Ascendente de Marcha

- Inter. Mudança Reducão de Marcha

32 - Interruptor da Trava do Diferencial

34 - Posicionamento do Volante

CH - Antavanca de Controle Lamina

JCG - "Joystick" do Contro (Chave)

41 - Interruptor Auxiliar da Pinça

42 - Interruptor Auxiliar do Torque 


\subsection{6 "Skidder" Tigercat modelo 630B}

Analisando-se o "skidder" Tigercat 630B em relação à distribuição espacial do posicionamento dos comandos, observa-se que somente no posicionamento "próximo" a distribuição dos comandos obteve uma melhor classificação, com 63,0\% atingindo os conceitos entre "bom" e "ótimo" (Tabela 16). Os comandos que são utilizados durante toda jornada de trabalho e encontrava-se em posição "bom", nas três posições do assento avaliadas, eram: pedal de acelerador para frente, "joystick" para controle da garra, alavanca de controle da lâmina, alavanca de câmbio e o volante. O único que encontrava-se em posição "regular" era o pedal acelerador de ré (Figura 31).

Tabela 16. Distribuição espacial dos dezenove comandos do "skidder" Tigercat 630B na avaliação espacial das coordenadas x-y e x-z

\begin{tabular}{lccc}
\hline \multirow{2}{*}{ Conceito } & \multicolumn{3}{c}{ Posicionamento do assento } \\
\cline { 2 - 4 } & Próximo & Médio & Extremo \\
\hline Ótimo & $4(21,0 \%)$ & ------- & ------ \\
Muito Bom & $2(10,5 \%)$ & ------ & $5(26,0 \%)$ \\
Bom & $6(31,5 \%)$ & $5(26,0 \%)$ & $7(37,0 \%)$ \\
Regular & $4(21,0 \%)$ & $7(37,0 \%)$ & $7(37,0 \%)$ \\
Ruim & $3(16,0 \%)$ & $7(37,0 \%)$ & $19(100,0 \%)$ \\
\hline \multicolumn{1}{c}{ Total } & $19(100,0 \%)$ & $19(100,0 \%)$ &
\end{tabular}

Quando comparada a distribuição espacial dos comandos para as três posições do assento entre os "skidders" Catterpillar 545 e o Tigercat 630B, observa-se que o "skidder" Tigercat 630B somente apresentou uma melhor distribuição dos seus comandos com a localização do assento em "próximo" (63,0\% contra 46,0\%), mas para as demais posições do assento o Caterpillar foi superior.

Na Tabela 17 constatou-se que entre os três posicionamentos avaliados do assento, a localização do assento em "extremo" proporcionou uma melhor 
distribuição dos instrumentos de verificação, interruptores de faróis e algumas luzes de advertências, onde 73,5\% receberam conceitos "muito bom" e "bom" (Figura 32).

Tabela 17. Distribuição espacial das dezenove luzes de advertência do "skidder" Tigercat 630B do ponto de vista do campo visual

\begin{tabular}{lccc}
\hline \multirow{2}{*}{ Conceito } & \multicolumn{3}{c}{ Posicionamento do assento } \\
\cline { 2 - 4 } & Próximo & Médio & Extremo \\
\hline Ótimo & ------- & $7(37,0 \%)$ & $12(63,0 \%)$ \\
Muito Bom & -------- \\
Bom & $7(34,0 \%)$ & ------- & $2(10,5 \%)$ \\
Regular & $12(63,0 \%)$ & ------ & $2(10,5 \%)$ \\
Ruim & ------- & $7(37,0 \%)$ & $3(16,0 \%)$ \\
\multicolumn{1}{r}{ Total } & $19(100,0 \%)$ & $19(100,0 \%)$ & $19(100,0 \%)$ \\
\hline
\end{tabular}




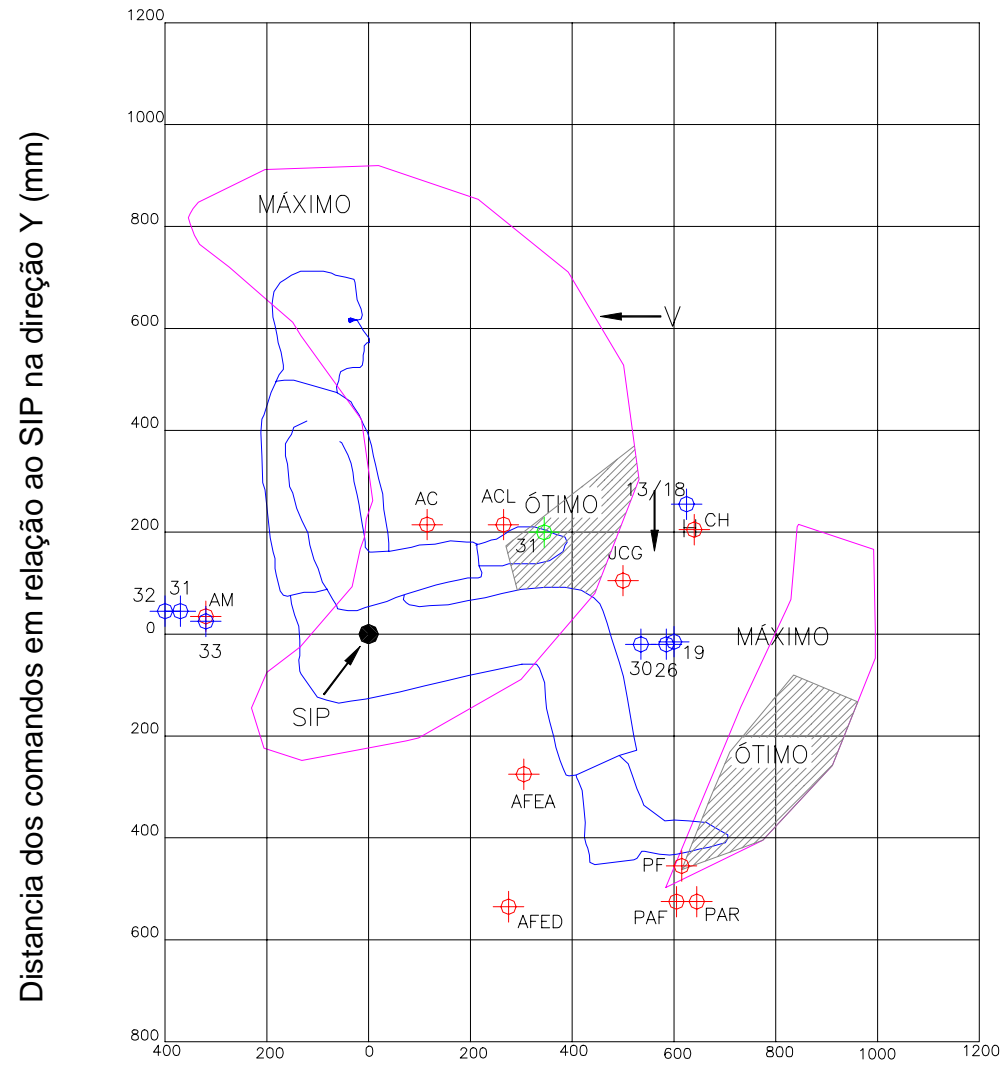

Distancia dos comandos em relação ao SIP na direção X (mm)

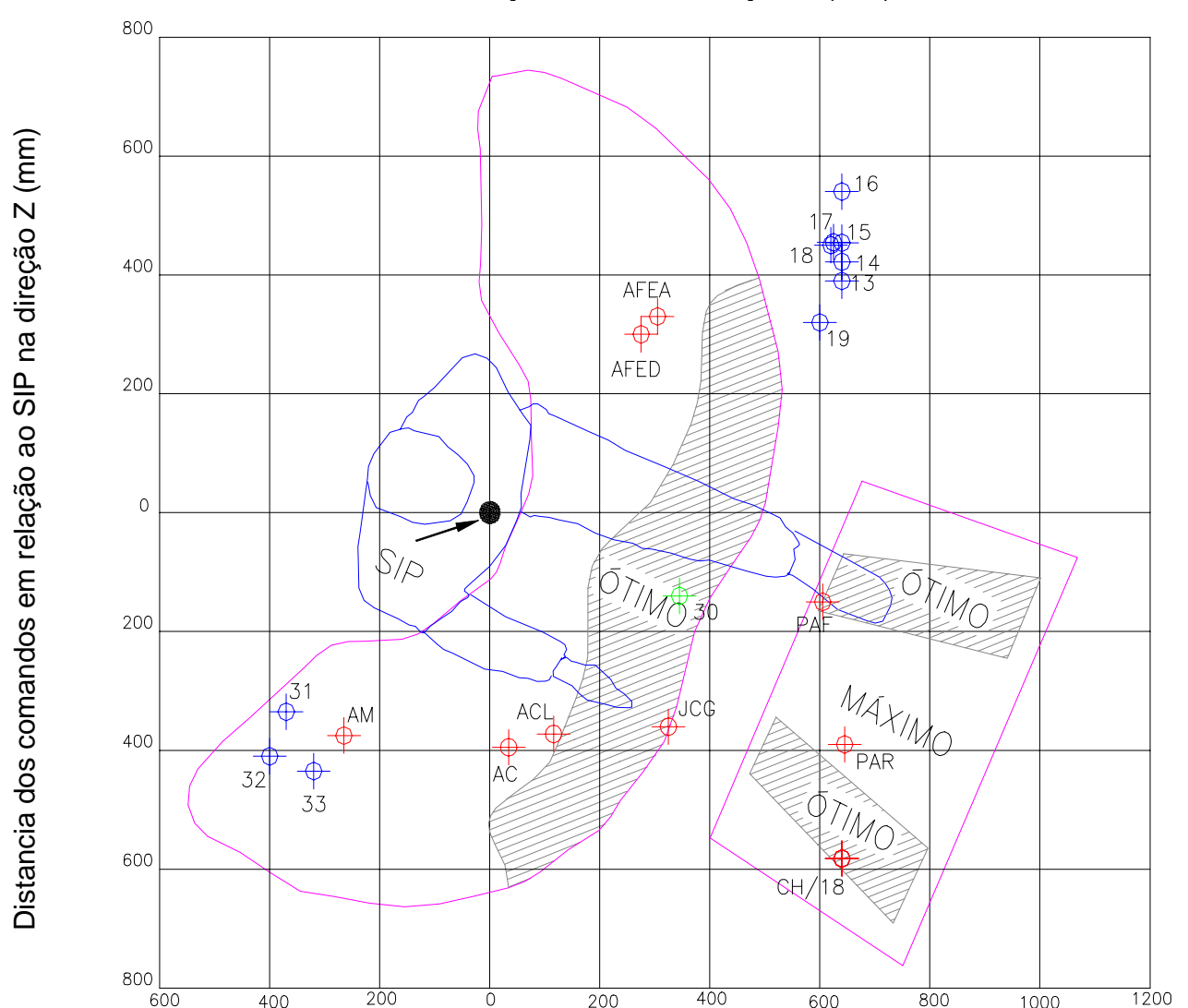

Distancia dos comandos em relação ao SIP na direção X (mm)

Figura 31 - Localização dos órgãos de comandos do "skidder" Tigercat 630 , nas três dimensões.

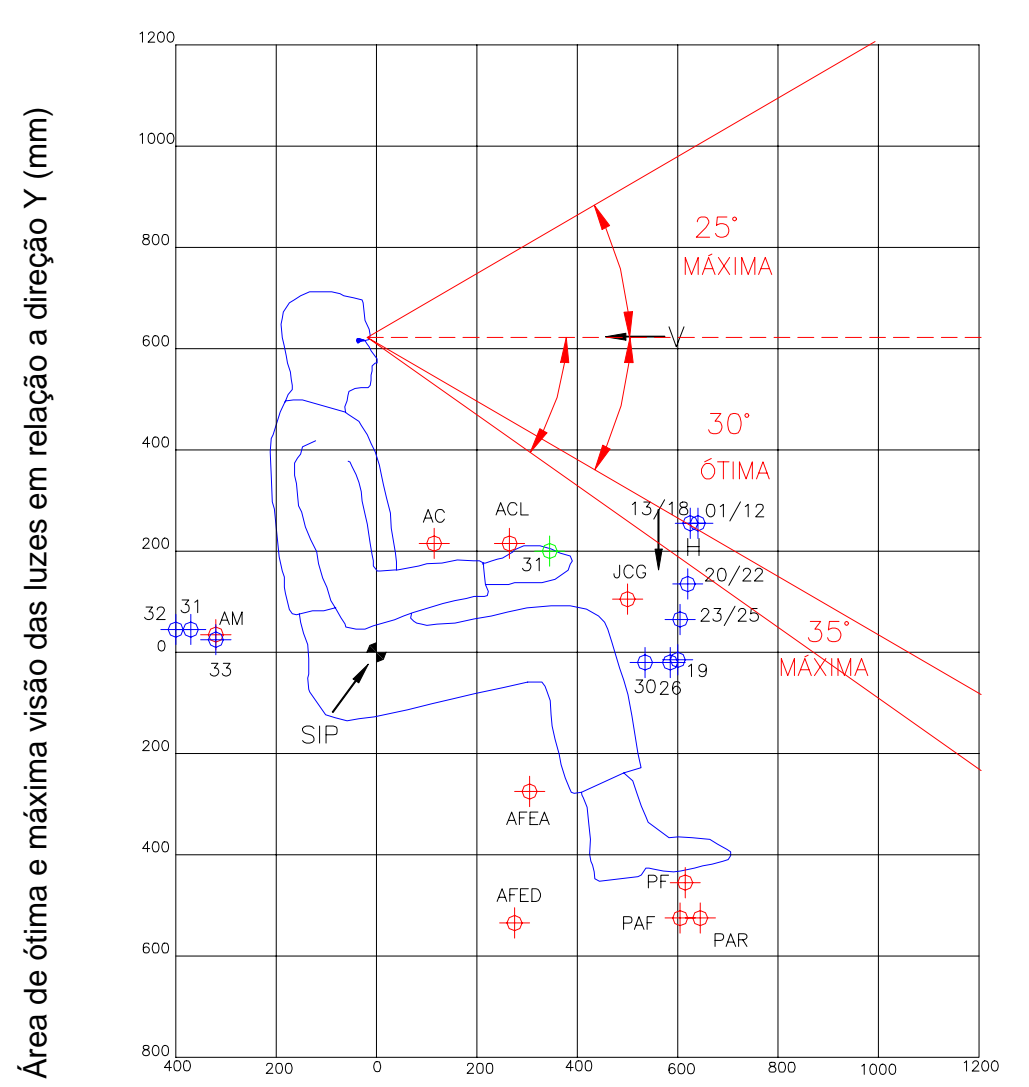

Área de ótima e máxima visão das luzes em relação a direção X (mm)

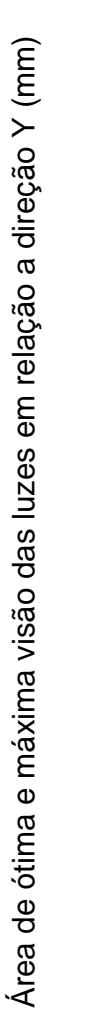

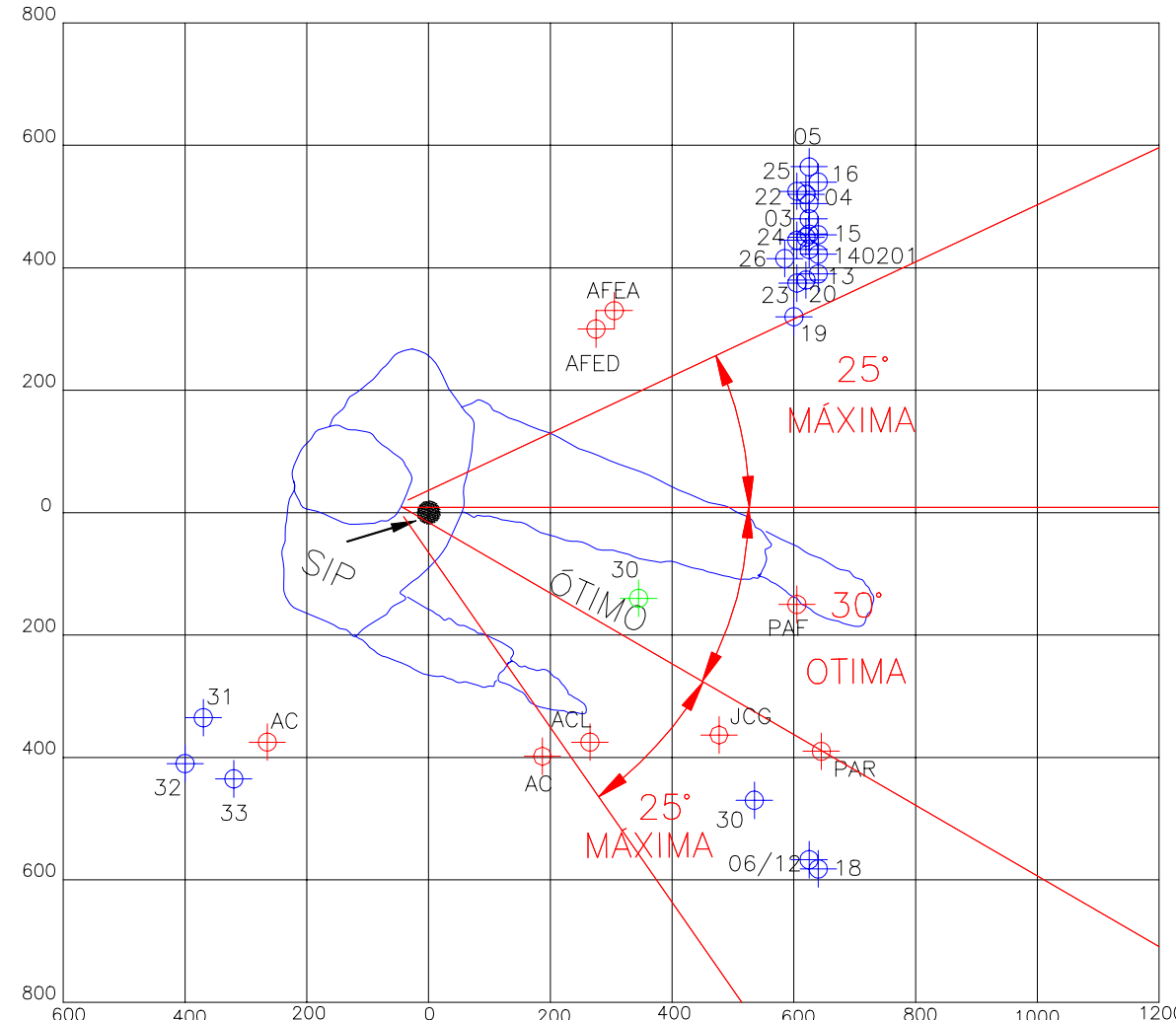

Área de ótima e máxima visão das luzes em relação a direção X (mm)

Figura 32 - Área de visão ótima e máxima de comandos do "skidder" Tigercat 630.
1- Luz do Nível de Óleo Hidráulico Baixo - Luz de Temperatura de Arrefecimento 3 - Luz da Pressão Oleo Motor 4 - Luz da válvula de descarga de bomba

5 - Luz do Freio de Estacionamento

7 - Luz de Temperatura Arrefecimento Baix

8 - Luz do Filtro de $\mathrm{Ar}$

9 - Luz do Filtro Hidrostático

10 - Luz da Pressão da Garra

12 Luz da Trava do Dierencial Dianteiro

13 - Interruptores das Luzes Frente

14 - Interruptores das Luzes Traseiras

15 - Interruptores da Luz de Serviço Motor

16 - Inter. Válvula Descarga Bomba Principa

17 - Interruptor de Ignição (Chave)

19 - Acendedor de Cigarro

20 - Relógio Temperatura de Resfriamento

21 - Relógio de Pressão do Óleo Motor

22 - Relogio Temperatura Oleo Hidraulico

23-Relógio Nível de Combustível

$24-$ Relógio de Amperagem

26 - Relógio de RPM

PAF - Pedal do Acelerador Frente

PAR - Pedal do Acelerador Ré

30 - Volante

JCG - Joystick do Controle da Garra

ACL - Alavanca de Controle Lâmina

AM - Acelerador Manual

31 - Inter. Posição Rotativa de Controle

Ar/Ventilador

32 - Inter. Controle Temperatura

33 - Inter. Posição de Circulação a

de Estacionamento

AFED - Alavar

(Desacionada) 


\subsubsection{Análise Comparativa entre os Modelos de Máquinas de Extração de}

\section{Madeira}

Para simplificar a comparação dos tratores florestais, os resultados da localização dos comandos com o assento na posição "média" (Tabelas 8, 9, 10 , 12, 14 e 16), foram agregados em dois únicos conceitos mais amplos: $A$ ("ótimo" + "muito bom" + "bom") e B ("regular" + "ruim") (Tabela 18).

Tabela 18. Avaliação da localização dos comandos (\%) com o assento localizado na posição "média"

\begin{tabular}{|c|c|c|}
\hline \multirow{2}{*}{ Tratores } & \multicolumn{2}{|c|}{ Conceito } \\
\hline & $A^{(*)}$ & $\mathrm{B}^{(* *)}$ \\
\hline & & \\
\hline "Forwarder" Valmet 890.2 & 66,7 & 33,3 \\
\hline "Forwarder" Timberjack 1210B & 48,5 & 51,5 \\
\hline "Forwarder" Timberjack 1710D & 43,0 & 57,0 \\
\hline "Forwarder" Volvo A25C & 42,0 & 58,0 \\
\hline "Skidder" Caterpillar 545 & 54,5 & 45,5 \\
\hline "Skidder" Tigercat 630B & 26,0 & 74,0 \\
\hline
\end{tabular}

Do ponto de vista ergonômico, foi relatada a hipótese que o "forwarder" é considerado uma máquina melhor projetada que o "skidder", contudo, de acordo com os resultados e avaliação feita neste estudo, essa hipotese nem sempre é verdadeira de acordo com os diferentes modelos de tratores testados. Com base nos dados da Tabela 18, o "forwarder" Vamet 890.2 apresentou a maior porcentagem dos comandos bem localizados, seguido do "skidder" Caterpillar 545, "forwarders" Timberjack 1210B, Timberjack 1710D e Volvo A25C e, por último, o "skidder" Tigercat 630B.

Pôde-se observar ainda que em todos os tratores avaliados a porcentagem de comandos que se encontravam localizados em posições "regular" e "ruim" eram, na maioria das vezes, interruptores de farol de trabalho, 
do ar condicionado, limpador de pára-brisa entre outros, geralmente pouco acionados durante a jornada de trabalho.

Quanto à localização das luzes de advertência e instrumentos mostradores, as Tabelas 11, 13, 15 e 17 foram sintetizadas na Tabela 19, com o posicionamento do assento localizado na posição "média".

Tabela 19. Avaliação da localização das luzes de advertência e instrumentos mostradores (\%) com o assento localizado na posição "média"

\begin{tabular}{|c|c|c|}
\hline \multirow{2}{*}{ Tratores } & \multicolumn{2}{|c|}{ Conceito } \\
\hline & $A^{(*)}$ & $\mathrm{B}^{(* *)}$ \\
\hline & & \\
\hline "Forwarder" Valmet 890.2 & 100,0 & ------- \\
\hline "Forwarder" Volvo A25C & 80,0 & 20,0 \\
\hline "Forwarder" Timberjack 1210B & ------- & 100,0 \\
\hline "Forwarder" Timberjack 1710D & ------- & 100,0 \\
\hline "Skidder" Caterpillar 545 & 75,0 & 25,0 \\
\hline "Skidder" Tigercat 630B & 53,0 & 37,0 \\
\hline
\end{tabular}

Na Tabela 19, observa-se que o "forwarder" Valmet 890.2 apresentou a totalidade de luzes de advertência e instrumentos mostradores bem localizados, seguido do Volvo A25C, "skidder" Caterpillar 545, "forwarder" Tigercat 630B e, por último, os "forwarders" Timberjack 1210B e Timberjack 1710D.

Os resultados obtidos com as avaliações ergonômicas foram comparados entre si, visando gerar subsídios para pesquisas futuras que busquem o aperfeiçoamento tecnológico da maquinaria florestal, priorizando a ergonomia como parte integrante dessa tecnologia. Neste caso, o "forwarder" Valmet 890.2 e o "skidder" Caterpillar 545 apresentaram a melhor distribuição de comandos, de acordo com o biótipo da amostra de operadores considerados neste estudo, devendo o mesmo ser ampliado com a análise da freqüência com 
que cada comando é acionado no decorrer da operação com a máquina. A baixa freqüência de uso de alguns comandos poderia justificar a sua colocação em uma posição menos adequada, não significando uma possivel recusa do modelo em questão para uso por parte de um operador brasileiro.

\subsection{Avaliação do Campo Visual do Operador}

$\mathrm{Na}$ Tabela 20 são apresentadas as áreas de projeção dos tratores florestais e a visibilidade nula para os campos visual estacionário (A), movimento dos olhos (B) e o obtido pelo movimento da cabeça do operador (C), em posição de deslocamento frontal com as máquinas (Figura 33 e 34).

Tabela 20. Áreas de visibilidade nula do solo (Avn), composta pela área do trator e a sombra projetada para os campos visuais A, B e C (Acv), para os operadores em posição de deslocamento frontal

\begin{tabular}{lcccccc}
\hline & \multicolumn{5}{c}{ Campo Visual } \\
\cline { 2 - 7 } \multicolumn{1}{c}{ Tratores } & \multicolumn{7}{c}{ A } & \multicolumn{2}{c}{ B } & \multicolumn{2}{c}{ C } \\
\cline { 2 - 8 } & Área & Sombra & Área & Sombra & Área & Sombra \\
& Trator & projetada & Trator & projetada & Trator & projetada \\
\hline & & \multicolumn{5}{c}{$\mathrm{m}^{2}$} \\
"Forwarder" Timberjack1210B & 2,51 & 13,06 & 2,88 & 37,00 & 2,36 & 29,94 \\
"Forwarder" Timberjack1710D & 2,62 & 19,4 & 2,99 & 39,00 & 2,48 & 37,48 \\
"Forwarder" Valmet 890.2 & 2,57 & 13,91 & 2,80 & 32,00 & 2,54 & 28,44 \\
"Forwarder" Volvo A25C & 2,84 & 21,8 & 3,20 & 44,30 & 2,70 & 35,24 \\
"Skidder" Caterpillar 545 & 5,04 & 31,07 & 2,58 & 36,07 & 1,37 & 47,74 \\
"Skidder" Tigercat 630B & 5,58 & 31,77 & 2,90 & 59,30 & 1,59 & 58,49 \\
\hline
\end{tabular}

Com base nos resultados obtidos, foi possível estabelecer uma relação entre as áreas Avn/Acv para os campos visuais, apresentada na Tabela 21. 


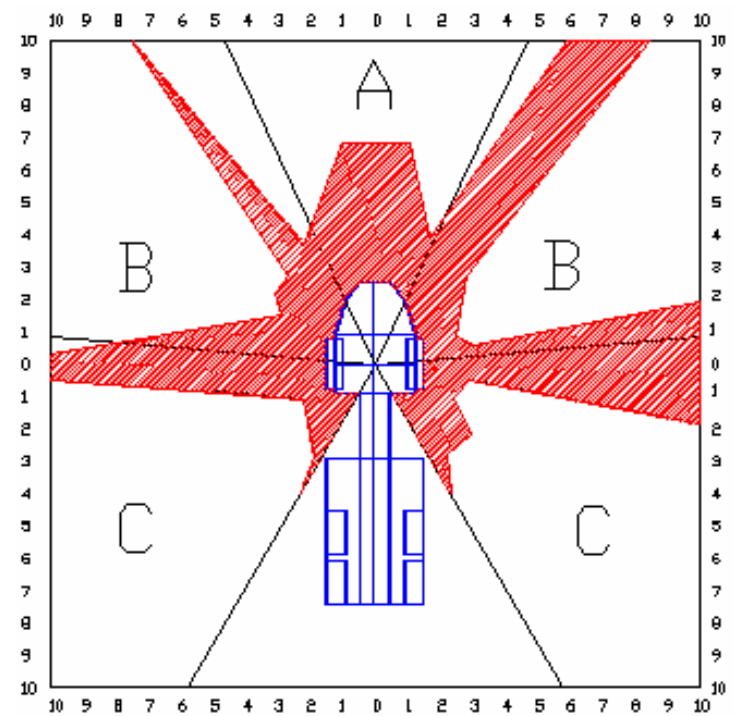

"Forwarder" Timberjack 1210B

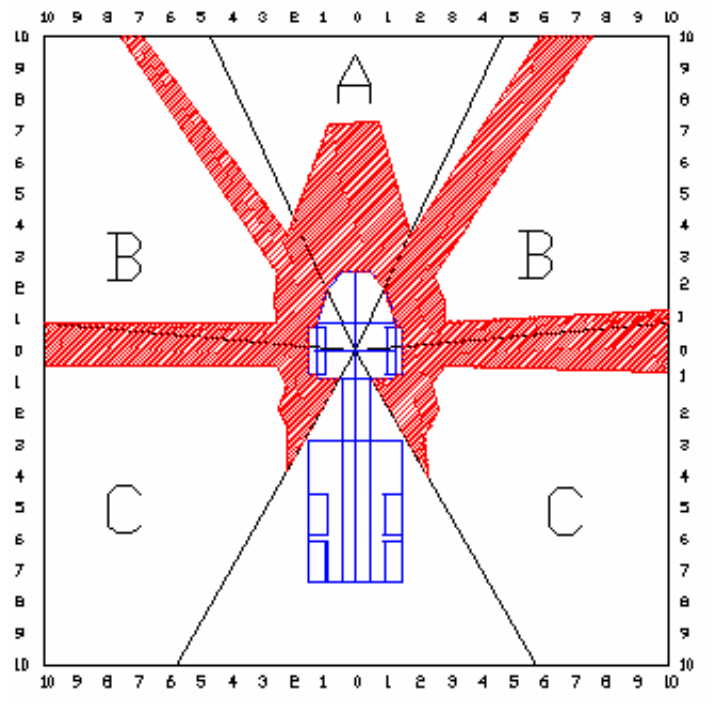

"Forwarder" Valmet 890.2

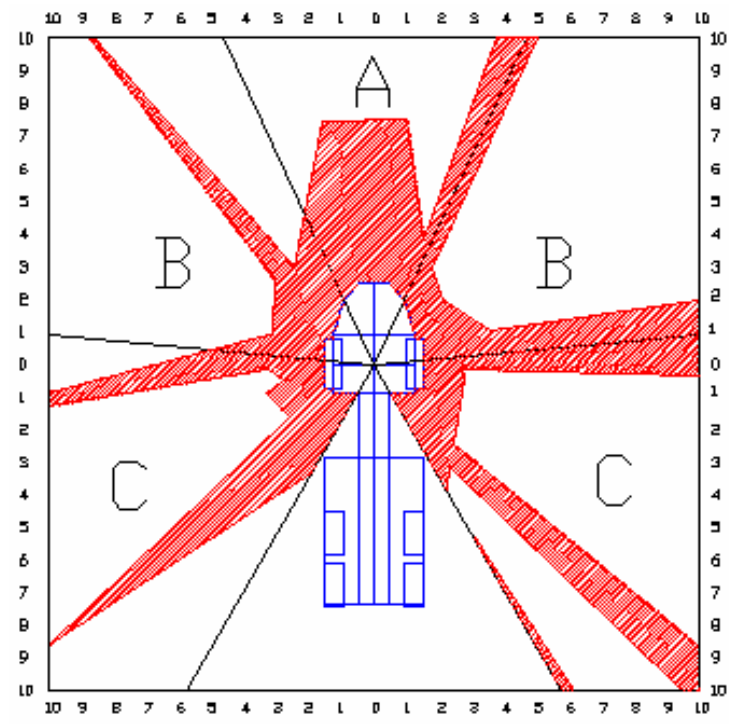

"Forwarder" Timberjack 1710D

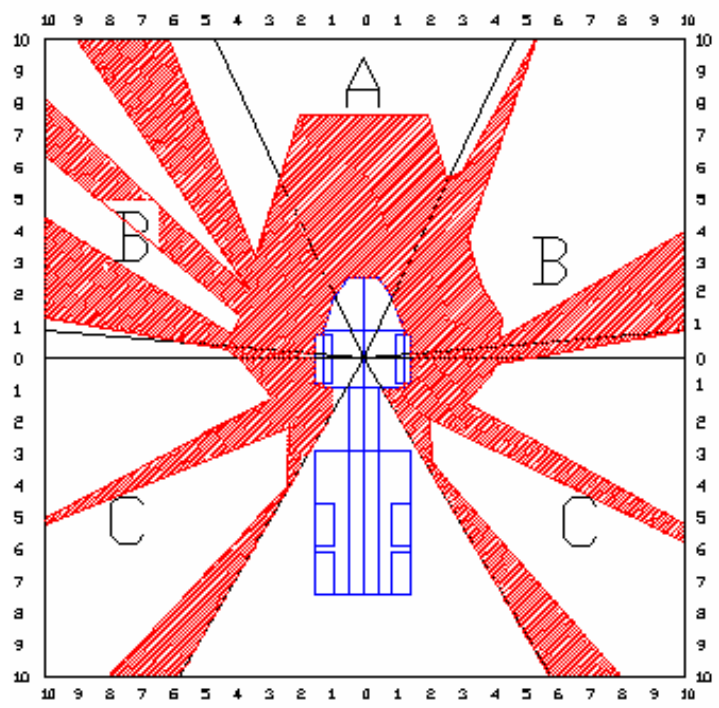

"Forwarder" Volvo A25C

Figura 33 - Área de visibilidade nula (hachurada) dos "forwarders" com os respectivos campos visuais dos operadores em posição de deslocamento frontal 

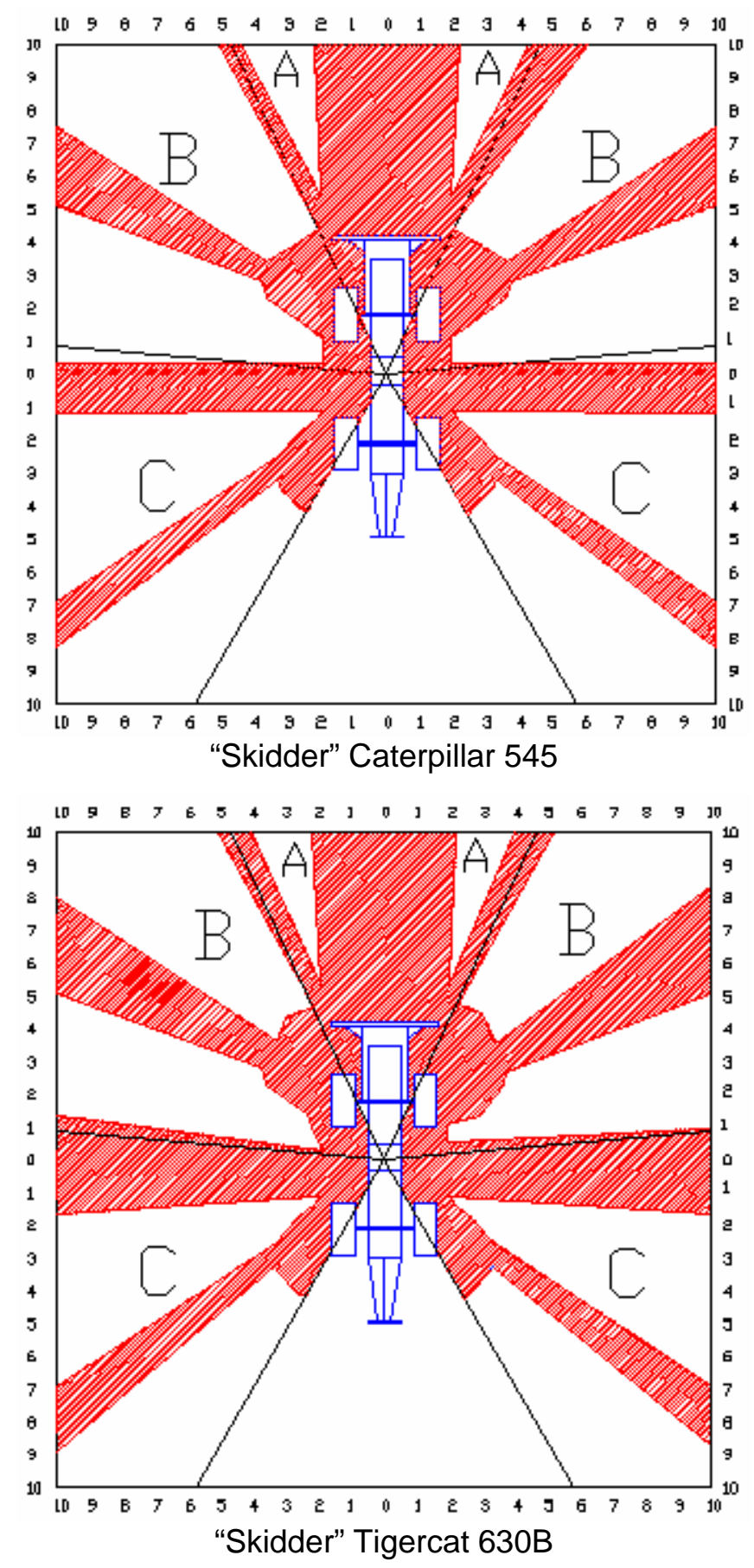

Figura 34 - Área de visibilidade nula (hachurada) dos "skidders" com os respectivos campos visuais dos operadores em posição de deslocamento com as máquinas 
De acordo com a Tabela 21 foi possível identificar que o "forwarder" Valmet 890.2 apresentou as melhores condições de visibilidade para os campos visuais em estudo, seguido do Timberjack 1210B, Timberjack 1710D e do Volvo A25C. Já para os "skidders", o Tigercat 630B apresentou as piores condições de visibilidade, ou seja, a maior relação Avn/Acv. Neste caso, todos os modelos de "forwarders" foram superiores aos "skidders", de certa forma corrobrando a hipótese deste trabalho. 
Tabela 21 - Relação (\%) entre a área de visibilidade nula (Avn) e a área total dos campos visuais A, B e C (Acv), dos operadores em posição de deslocamento com a máquina

\begin{tabular}{|c|c|c|c|c|c|c|c|c|c|c|}
\hline \multirow{3}{*}{ Tratores } & \multicolumn{9}{|c|}{ Campo Visual } & \multirow{3}{*}{$\begin{array}{l}\bar{\Delta}^{(* *)} \\
(\%)\end{array}$} \\
\hline & \multicolumn{3}{|c|}{ A } & \multicolumn{3}{|c|}{ B } & \multicolumn{3}{|c|}{ C } & \\
\hline & $\begin{array}{l}\text { Avn } \\
\left(m^{2}\right)\end{array}$ & $\begin{array}{l}\text { Acv } \\
\left(m^{2}\right)\end{array}$ & $\begin{array}{c}\left.\Delta_{\mathrm{a}}{ }^{*}\right) \\
(\%)\end{array}$ & $\begin{array}{l}\text { Avn } \\
\left(\mathrm{m}^{2}\right)\end{array}$ & $\begin{array}{l}\text { Acv } \\
\left(m^{2}\right)\end{array}$ & $\begin{array}{c}\Delta_{\mathrm{b}}{ }^{(*)} \\
(\%)\end{array}$ & $\begin{array}{l}\text { Avn } \\
\left(m^{2}\right)\end{array}$ & $\begin{array}{l}\text { Acv } \\
\left(m^{2}\right)\end{array}$ & $\begin{array}{c}\left.\Delta_{\mathrm{c}}{ }^{*}\right) \\
(\%)\end{array}$ & \\
\hline "Forwarder" Valmet 890.2 & 16,48 & \multirow{6}{*}{46,6} & 35,36 & 34,8 & \multirow{6}{*}{142,5} & 24,42 & 30,98 & \multirow{6}{*}{149,4} & 20,74 & 26,84 \\
\hline "Forwarder" Timberjack 1210B & 15,57 & & 33,41 & 39,88 & & 27,99 & 32,3 & & 21,62 & 27,67 \\
\hline "Forwarder" Timberjack 1710D & 22,02 & & 47,25 & 41,99 & & 29,47 & 39,96 & & 26,75 & 34,49 \\
\hline "Forwarder" Volvo A25C & 24,64 & & 52,88 & 47,5 & & 33,33 & 37,94 & & 25,39 & 37,20 \\
\hline "Skidder" Caterpillar 545 & 36,11 & & 77,49 & 38,65 & & 27,12 & 49,11 & & 32,87 & 45,83 \\
\hline "Skidder" Tigercat 630B & 37,35 & & 80,15 & 62,2 & & 43,65 & 60,08 & & 40,21 & 54,67 \\
\hline
\end{tabular}

(*) $\Delta=(\mathrm{Avn} / \mathrm{Acv})^{*} 100$

${ }^{(*)} \bar{\Delta}=\left(\Delta_{\mathrm{a}}+\Delta_{\mathrm{b}}+\Delta_{\mathrm{c}}\right) / 3$ 


\subsection{Avaliação Geral dos Operadores}

\subsection{1 "Forwarders"}

$\mathrm{Na}$ avaliação por parte dos operadores, o "forwarder" Timberjack 1210B foi o que apresentou melhores resultados, seguido do Timberjack 1710D, Valmet 890.2 e Volvo A25C, com as médias sendo apresentadas na Tabela 22.

Tabela 22. Médias atribuídas pelos operadores de "forwarders"

\begin{tabular}{lcccc}
\hline \multirow{2}{*}{ Características } & \multicolumn{2}{c}{ Timberjack } & Valmet & Volvo \\
\cline { 2 - 5 } & $1210 \mathrm{~B}$ & $1710 \mathrm{D}$ & 890.2 & $\mathrm{~A} 25 \mathrm{C}$ \\
\hline Acesso a cabine & 9,3 & 10,0 & 10,0 & 7,0 \\
Postura de trabalho & 9,3 & 10,0 & 10,0 & 8,5 \\
Cabine (espaço interno) & 10,0 & 9,0 & 3,0 & 7,6 \\
Visibilidade & 9,3 & 7,3 & 10,0 & 7,3 \\
Conforto do assento & 8,5 & 10,0 & 10,0 & 9,3 \\
Posicionamento dos controles & 10,0 & 10,0 & 10,0 & 8,8 \\
Máquina em operação & 8,5 & 10,0 & 7,0 & 7,7 \\
Informações & 10,0 & 7,3 & 10,0 & 8,8 \\
Nível de ruído & 8,5 & 9,0 & 10,0 & 8,8 \\
Nível de vibração & 9,3 & 8,3 & 3,0 & 9,0 \\
Nível do controle climatológico & 9,3 & 9,0 & 10,0 & 9,1 \\
Emissão de Gases & 9,3 & 10,0 & 10,0 & 9,3 \\
Intensidade da luz (faróis) & 10,0 & 7,0 & 10,0 & 8,1 \\
Treinamento e instruções & 10,0 & 10,0 & 10,0 & 10,0 \\
Manutenção & 9,3 & 10,0 & 10,0 & 9,0 \\
\hline \multicolumn{1}{c}{ Médias } & $\mathbf{9 , 3}$ & $\mathbf{9 , 1}$ & $\mathbf{8 , 8}$ & $\mathbf{8 , 5}$ \\
\hline
\end{tabular}

As entrevistas serviram para identificar o perfil e caracterizar as condições de trabalho dos operadores, além de possíveis problemas ergonômicos das máquinas. Quando comparadas as avaliações ergonômicas com as notas atribuídas pelos operadores, nota-se alguma semelhança entre os resultados relativos ao posicionamento dos controles, pois o "forwarder" Valmet 890.2 esteve entre os melhores, ficando o "forwarder" Volvo A25C com a pior 
avaliação dos comandos. Contudo, o "forwarder" Valmet 890.2 poderia ser melhor nas avaliações atribuídas pelos operadores, pois segundo eles o modelo apresenta algumas características indesejáveis que são o espaço interno da cabine e nível de vibração, não avaliados neste estudo.

$\mathrm{Na}$ avaliação do campo visual dos operadores, o confronto dos resultados com a opinião dos operadores também mostrou-se válido, sendo que mais uma vez o "forwarder" Valmet 890.2 apresentou as melhores condições de visibilidade. 


\subsection{2 "Skidders"}

$\mathrm{Na}$ avaliação por parte dos operadores o "skidder" Tigercat $630 \mathrm{~B}$ foi o que apresentou melhores resultados, seguido do Caterpillar 545, com as médias sendo apresentadas na Tabela 23.

Tabela 23. Médias atribuídas pelos operadores de "skidders"

\begin{tabular}{lcc}
\hline \multirow{2}{*}{ Características } & \multicolumn{2}{c}{ Skidders } \\
\cline { 2 - 3 } & Tigercat 630 B & Caterpillar 545 \\
\hline Acesso à cabine & 10,0 & 6,5 \\
Postura de trabalho & 7,9 & 6,0 \\
Cabine (espaço interno) & 7,0 & 8,5 \\
Visibilidade & 6,4 & 6,5 \\
Conforto do assento & 8,3 & 7,3 \\
Posicionamento dos controles & 7,9 & 7,8 \\
Máquina em operação & 8,6 & 8,5 \\
Informações & 9,1 & 9,3 \\
Nível de ruído & 5,6 & 7,3 \\
Nível de vibração & 8,7 & 4,0 \\
Nível do controle climatológico & 8,7 & 9,3 \\
Emissão de Gases & 10,0 & 9,3 \\
Intensidade da luz (faróis) & 6,4 & 7,3 \\
Treinamento e instruções & 10,0 & 9,3 \\
Manutenção & 7,9 & 10,0 \\
\hline \multicolumn{1}{c}{ Médias } & $\mathbf{8 , 2}$ & $\mathbf{7 , 8}$
\end{tabular}

Quando analisados os resultados da Tabela 23, observa-se que algumas característica apresentaram condições desagradáveis, como por exemplo, o nível de vibração, onde o "skidder" Tigercat 630B apresentou melhores condições, sem contudo atingir nota máxima. Comparando-se os resultados das características estudadas, observa-se que o posicionamento dos controles e a visibilidade, não apresentaram diferenças nas notas atribuídas pelos operadores, não repetindo os resultados da avaliação quantitativa. 


\section{CONCLUSÕES}

A hipótese apresentada neste estudo, quanto ao melhor projeto ergonômico do "forwarder" em relação ao "skidder", não se comprovaram para todos os modelos aqui considerados. A melhor máquina avaliada, quanto ao posicionamento de comandos, de acordo com o biótipo de um conjunto de operadores brasileiros, foi o "forwarder" Valmet 890.2, seguido do "skidder" Caterpillar 545, sendo os únicos tratores que apresentaram mais da metade dos comandos bem posicionados, $66,7 \%$ e $54,5 \%$ respectivamente.

O "forwarder" Valmet 890.2 também apresentou o melhor campo visual, sendo que, neste quesito, todos os modelos de "forwarders" foram superiores aos "skidders".

Os resultados deste estudo, demonstraram um projeto ergonômico não muito favorável ao conjunto de operadores brasileiros considerados, quanto ao posicionamento da totalidade dos comandos, devem ser complementados por outro estudo quanto à freqüência de uso dos mesmos, pois poderia justificar o posicionamento de um comando fora da faixa ideal em virtude de seu uso pouco freqüente. 


\section{REFERÊNCIAS BIBLIOGRÁFICAS}

ASSOCIAÇÃO BRASILEIRA DE NORMAS TÉCNICAS. Ergonomia. http://www.abergo.org.br (20 jun. 2003).

ASSOCIAÇÃO BRASILEIRA DE NORMAS TÉCNICAS. NBR NM-ISO 5353: máquinas rodoviárias, tratores e máquinas agrícolas e florestais - ponto de referência do assento. Rio de Janeiro, 1999. 05 p.

BAESA, A.B.; CASABELLA, E.P. Avaliação ergonômica de uma cabine para colhedora de cana-de-açúcar. Revista Brasileira de Saúde Ocupacional, v.19, n.72, p.59-64, 1991.

CHEREM, A.J. Diagnósticos dos distúrbios osteomusculares relacionados ao trabalho. Rio de Janeiro: Teoria \& Prática Editora, 2001.

CHUDAKOV, D.A. Fundamentos de la teoria y el cálculo de tractors y automóviles. Moscow: Mir, 1977. 435 p.

COUTO, H.A. Ergonomia aplicada ao trabalho: coletânea dos cadernos Ergo. Belo Horizonte: Cultura, 1987. 432 p.

COUTO, H.A. Ergonomia aplicada ao trabalho: o manual técnico da máquina humana. Belo Horizonte: Ergo Editora, 1995. v.2, 353 p.

DEBIASI, H. Diagnósticos dos acidentes de trabalho e das condições de segurança na operação de conjuntos tratorizados. Santa Maria, 2003. 291 p. Dissertação (Mestrado) - Universidade Federal de Santa Maria.

DUL, J.; WEERDMEESTER, B. Ergonomia prática. São Paulo: Edgard Blücher, 2001. $147 \mathrm{p}$.

FIEDLER, N.C. Avaliação ergonômica de máquinas utilizadas na colheita de madeira. Viçosa, 1995. 126 p. Dissertação (Mestrado) - Universidade Federal de Viçosa. 
FONTANA, G.; SILVA, R.P.; LOPES, A. et al. Avaliação de características ergonômicas no posto do operador em colhedoras combinadas. Engenharia Agrícola, 2004. v.24, n.3, p. $684-694$.

GRANDJEAN, E. Fitting the task to the man: an ergonomic approach. London: Taylor \& Francis, 1982. 376 p.

GRANDJEAN, E. Manual de ergonomia. 4.ed. Porto Alegre: Artes Médicas, 1998. $338 \mathrm{p}$.

IIDA, I. Ergonomia: projeto e produção. São Paulo: Edgard Blücher, 2001. $451 \mathrm{p}$.

INTERNATIONAL ORGANIZATION OF STANDARDIZATION. Agricultural tractors - operator's field of vision: ISO 5721. Local 1981. 7 p.

JÜRGENS, H.W.; AUNE, I.A.; PIEPER, G. International data on anthropometry (Occupational Safety and Health Series n.65). Geneva: International Labour Office. 1990.

KOCHLER, M.K. A ergonomia nas colheitadeiras fabricadas no Brasil: Um estudo da evolução. Santo Ângelo,1999. 60 p. Monografia (Especialização) Universidade Regional Integrada.

LAVILLE, A. Ergonomia. São Paulo: EPU, 1977. 101 p.

LILJEDAHL, J.B.; TURNQUIST, P.K.; SMITH, D.W. et al. Tractors and their power units. 4.ed. St. Joseph: ASAE, 1996. 463 p.

LIMA, J.S.S. Avaliação da força de arraste, compactação do solo e fatores ergonômicos num sistema de colheita de madeira utilizando os tratores Feller-Buncher e Skidder. Viçosa, 1998. 128 p. Dissertação (Doutorado) Universidade Federal de Viçosa.

MACHADO, C.C. Colheita florestal. Viçosa: UFV. 2002. 468 p.

MAKKONEN, I. Choosing a wheeled shortwood forwarder. (FERIC Technical Note, 136), Quebec: Feric. 1989. 12 p.

MARQUES, R.T. Otimização de um sistema de transporte florestal rodoviário pelo método PERT/COM. Viçosa, 1994. 95 p. Dissertação (Mestrado) Universidade Federal de Viçosa.

MÁRQUEZ, L. Solo Tractor 90, In: Ergonomia e segurança no projeto e utilização de máquinas agrícolas, p. 177-194, Santa Maria - RS, 1997. 
MEIRELLES, C.E. Tratores agrícolas. Revista Brasileira de Saúde Ocupacional, v. 4 , n.14, p.1-80, 1976.

MENEGAS, M.T. Apreciação ergonômica da cabina de tratores agrícolas visibilidade. Santa Maria, 2001. 218 p. Dissertação (Mestrado) Universidade Federal de Santa Maria.

MENEZES, J.F.; MAZIERO, J.V.; YAMASHITA, R.Y. et al. Avaliação de características de visibilidade apresentadas por um grupo de tratores de rodas. Campinas: IAC, 1985. (Boletin Técnico, 101.) 17 p.

MINETTE, L.J. Analise de fatores operacionais e ergonômicos na operação de corte florestal com moto-serra. Viçosa, 1996. 211 p. Tese (Doutorado) Universidade Federal de Viçosa.

MORAES, A. Aplicação de dados antropométricos; dimensionamento da interface homem - máquina. Rio de Janeiro, 1983. 522 p. Dissertação (Mestrado) - Universidade Federal do Rio de Janeiro.

PANERO, J.; ZELNIK, M. Las dimensiones humanas en los espacios interiores: estándares antropométricos. 5.ed. México: G. Gili, 1993. 320 p.

PATOSAARI, P. Forestry accidents an accident prevention in Finland. In: INTERNATIONAL SEMINAR ON ERGONOMICS APLLIED TO FLORESTRY, Ossiach, 1983. Proceedings. p. 99-107.

PINHEIRO, P.R.L.; MARZIALE, M.H.M. A culpa é sempre da cadeira mas nem sempre é a vilã. Revista CIPA, v.21, n.247, p. 106-109, jun.2000.

ROBIN, P. Segurança e ergonomia em maquinaria agrícola: tratores agrícolas. São Paulo: IPT, 1987. 22 p.

ROSSI, M.A.; SILVA, J.C.P. Ergonomia e os fatores de risco na produção. Revista CIPA, v.22, n. 237, p. 53-60, abr.2001.

ROZIN, D. Conformidade do posto de operação de tratores agrícolas nacionais com normas de ergonomia e segurança. Santa Maria, 2004. 187 p. Dissertação (Mestrado) - Universidade Federal de Santa Maria.

SANTOS, C.M.D. Móveis ergonômicos. Revista Proteção, v.12, n.93, p. 62-65, set.1999.

SANTOS, N.; FIALHO, F. Manual da análise ergonômica no trabalho. Curitiba: Gênesis, 1997. 315 p. 
SCHLOSSER, J.F.; DEBIASI, H.; PARCIANELLO, G. et al. Antropometria aplicada aos operadores de tratores agrícolas. Ciência Rural, v.32, n.6, p.983-988, 2002 a.

SCHLOSSER, J.F.; DEBIASI, H.; PARCIANELLO, G. et al. Caracterização dos acidentes com tratores agrícolas. Ciência Rural, v.32, n.6, p.977-981, 2002 b.

SEIXAS, F. Introdução a ergonomia: aplicações no trabalho florestal. Piracicaba, ESALQ, 1983. $41 \mathrm{p}$.

SERRANO, R.C. Novo equipamento de medições antropométricas. São Paulo: FUNDACENTRO, 1996. 32 p.

SILVA, C.B. Avaliação ergonômica de máquinas utilizadas na colheita de eucalipto. Lavras, 2002. 116 p. Dissertação (Mestrado) - Universidade Federal de Lavras.

SILVA, E.M. Avaliação da preferência de cadeiras para diferentes tipos de trabalhos de escritório. Porto Alegre, 2003. 265 p. Dissertação (Mestrado) Universidade Federal do Rio Grande do Sul.

SILVEIRA, G.M. Tratores gigantes, a tendência atual. A Granja, v.1, n.10, p.48-53, 1987.

SKOGFORSK - (The Forestry Research Institute of Sweden). Ergonomic guidelines for forest machines. Uppsala, Sweeden: Swedish National Institute for Working Life, $1999.86 \mathrm{p}$.

SOUZA, A.P. Colheita e transporte florestal. Viçosa: UFV, 1985. 104 p.

TEWARK, V.K.; DATTA, R.K. Development of a wetland seeder from mechanical and ergonomical considerations. Agricultura e Mechanization in Asia, Africa and Latin America, v.14, n.3, p.21 - 27. 1983.

THOMAS, R.E.;TUCKER, D.P.W.; SMITH, L.A. et al. The anthropometry of Forest machine operators in the southrn USA. Journal of Forest Engineering, v.5, n.2, p.33-41, 2001.

VIEIRA, S.I. Manual de saúde e segurança do trabalho. Florianópolis: Mestra Editora, 2000. 190 p.

WISNER, A. Por dentro do trabalho: ergonomia: método e técnica. São Paulo: FTD/Obaré, 1987. 189 p. 
WITNEY, B. Choosing and using farm machines. Harlow: Longman Scientific and Technical, 1988. p. 28-94.

WOODSON, W.E.; CONOVER, D.W. Human engineering for equipment designers. 2.ed. Berkeley: University of California Press, 1964. 420 p.

YADAV, R.; TEWARI, V. K. Tractor operator workplace design: a review. Journal of Terramechanics, v. 35, p. 41-53, 1998.

YAMASHITA. R.Y. Avaliação das condições de trabalho e da exposição à vibração do operador de máquinas na colheita florestal. Piracicaba, 2002. 55 p. Dissertação (Mestrado) - Escola Superior de Agronomia Luiz de Queiroz, Universidade de São Paulo.

ZANDER, J. Ergonomics in machine desing: a case study of the selfpropelled combine harvester. Wageningen: Mededelingen Landboowhogeschool, 1972. $161 \mathrm{p}$. 